\author{
UNIVERSIDADE DE SÃO PAULO \\ FACULDADE DE FILOSOFIA, LETRAS E CIÊNCIAS HUMANAS \\ DEPARTAMENTO DE LETRAS CLÁSSICAS E VERNÁCULAS \\ PROGRAMA DE PÓS-GRADUAÇÃO EM LITERATURA BRASILEIRA
}

VINICIUS GALERA DE ARRUDA

Fora do lugar - a ficção de José Agrippino de Paula

- Versão corrigida -

São Paulo

2016 


\author{
UNIVERSIDADE DE SÃO PAULO \\ FACULDADE DE FILOSOFIA, LETRAS E CIÊNCIAS HUMANAS \\ DEPARTAMENTO DE LETRAS CLÁSSICAS E VERNÁCULAS \\ PROGRAMA DE PÓS-GRADUAÇÃO EM LITERATURA BRASILEIRA
}

\title{
Fora do lugar - a ficção de José Agrippino de Paula
}

- Versão corrigida -

Vinicius Galera de Arruda

Dissertação apresentada ao Programa de Pós-Graduação em Literatura Brasileira do Departamento de Letras Clássicas e Vernáculas da Faculdade de Filosofia, Letras e Ciência Humanas da Universidade de São Paulo, para a obtenção do título de Mestre em Literatura Brasileira.

Orientador: Prof ${ }^{a}$. Dr ${ }^{\mathrm{a}}$. Eliane Robert Moraes

São Paulo 
Autorizo a reprodução e divulgação total ou parcial deste trabalho, por qualquer meio convencional ou eletrônico, para fins de estudo e pesquisa, desde que citada a fonte.

Catalogação na Publicação

Serviço de Biblioteca e Documentação

Faculdade de Filosofia, Letras e Ciências Humanas da Universidade de São Paulo

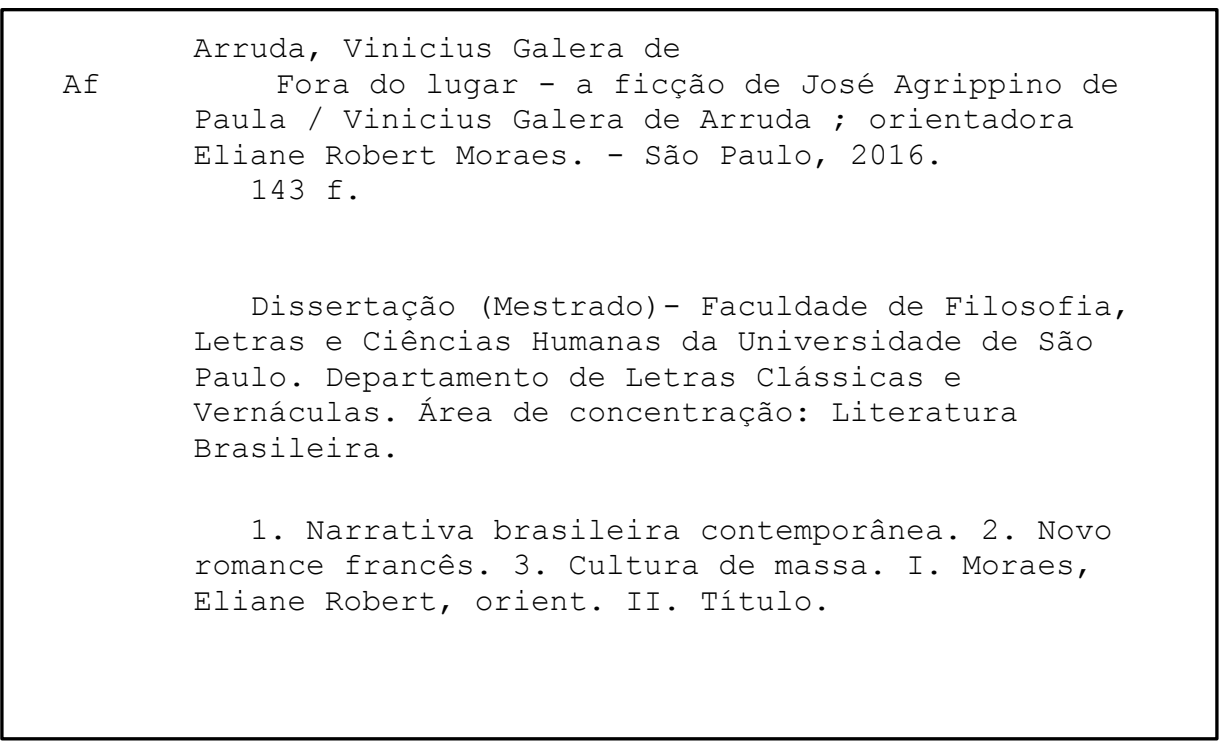


Nome: ARRUDA, Vinicius Galera de. Fora do lugar - a ficção de José Agrippino de

Paula. Dissertação apresentada à Faculdade de Filosofia, Letras e Ciências Humanas da Universidade de São Paulo, para a obtenção do título de Mestre em Literatura Brasileira.

Aprovado em:

Banca Examinadora

Prof $^{\mathrm{a}}$. Dr ${ }^{\mathrm{a}}$. Eliane Robert Moraes (Orientadora)

Instituição: Departamento de Letras Clássicas e Vernáculas (DLCV - USP)

Julgamento: Assinatura:

Prof $^{\mathrm{a}}$. Dr ${ }^{\mathrm{a}}$. Evelina de Carvalho Sá Hoisel (Titular)

Instituição: Universidade Federal da Bahia (UFBA)

Julgamento: Assinatura:

Prof. Dr. Ivan Francisco Marques (Titular)

Instituição: Departamento de Letras Clássicas e Vernáculas (DLCV - USP)

Julgamento: Assinatura:

Prof. Dr. Jefferson Agostini Mello (Suplente)

Instituição: Escola de Artes, Ciências e Humanidades (EACH - USP)

Julgamento: Assinatura:

Prof. Dra. Marta Dantas da Silva (Suplente)

Instituição: Universidade de Estadual de Londrina (UEL)

Julgamento: Assinatura:

Prof. Dra. Mariza Martins Furquim Werneck (Suplente)

Instituição: Pontifícia Universidade Católica (PUC-SP)

Julgamento: Assinatura: 
Para Assunta Maria Galera de Arruda e Nilton de Arruda 


\section{AGRADECIMENTOS}

A Eliane, pelos ensinamentos, pelo cuidado, pela paciência e pela generosidade com que me conduziu até aqui. Fundamentalmente, pela amizade.

Aos professores Luiz Roncari e Leopoldo Bernucci.

A Juliana Schmitt, Ronnie Cardoso, Estevão Azevedo, Nina Maniçoba Ferraz, Juliana

Caldas, Aline Novaes, Marcos Visnardi, Bruno Ribeiro de Lima e Maria Carolina Fabri, membros do grupo de estudos da professora Eliane, e a Marta Dantas, membro da banca de qualificação, pelas leituras críticas dos meus textos, que enriqueceram este trabalho.

A Adel Fauzetdinova, Gabriel Lellis, Bruna de Alencar, Valter Silva, Viviane Taguchi, Raphael Salomão, Robson Viturino e Virgínia Mendonça Knabben.

A meus pais, Assunta e Nilton, e a minha irmã, Fauzia Cristina Arruda, pelo amor e respeito, sentimentos recíprocos que tanto me inspiram.

A Juliana Luz Bacci e Susana Berbert, que me ajudaram a seguir, compartilhando meu entusiasmo e me aconselhando diante dos recuos. 


\section{RESUMO}

Este trabalho se propõe a estudar a prosa de ficção de José Agrippino de Paula, sobretudo os romances Lugar público e PanAmérica. Nosso objetivo é demonstrar como essas obras absorveram técnicas de vanguarda, notadamente do chamado Novo Romance Francês, que não eram comuns na prosa de ficção brasileira no período em que foram publicadas, a década de 1960. Além disso, com PanAmérica, o autor propôs uma leitura original da mitologia contemporânea configurada pela cultura de massa. Acreditamos que, ainda hoje, esses livros se constituem como romances de excesso e de exceção, já que, por suas inovações formais, não se enquadraram na tradição do romance brasileiro, o que acabou por relegá-los à margem da nossa história literária. 


\begin{abstract}
This work aims to study the fiction written by José Agrippino de Paula, mainly the novels Lugar público e PanAmérica. Our goal is to demonstrate how these works absorbed the Avant-garde literary techniques, especially the so-called Nouveau Roman, that were still not common in the Brazilian fiction prose in the 1960s, the time of their publication. Moreover, with PanAmérica, the author proposes a new way of reading the contemporary mythology molded by mass culture. We believe that even today, the books can be considered both excessive and exceptional. Due to their formal innovations, they escape the traditional Brazilian novel's boundaries, which at the same time has relegated them to the margins of our literary history.
\end{abstract}




\section{SUMÁRIO}

INTRODUÇÃO - UMA OBRA (E UM AUTOR) FORA DO LUGAR

CAPítulo 1 - LUGAR PÚBLICo, UM ROMANCE NA SUPERFície DO

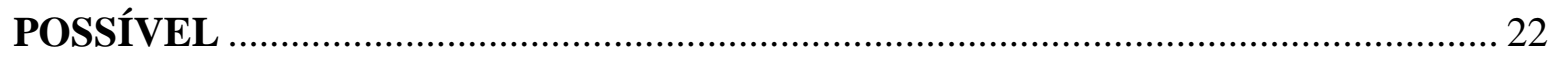

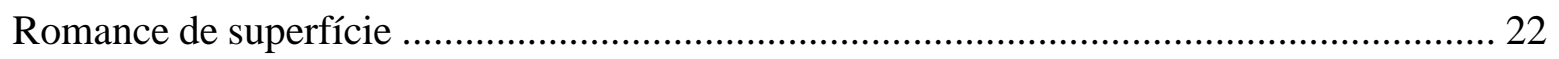

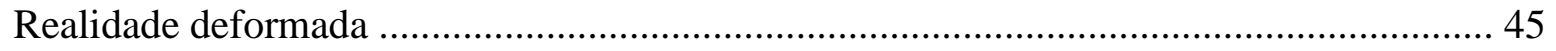

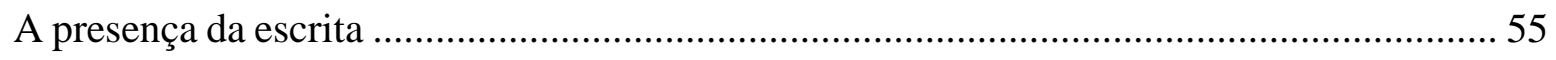

CAPÍTULO 2 - PANAMÉRICA EPOPEIA POP ....................................................... 70

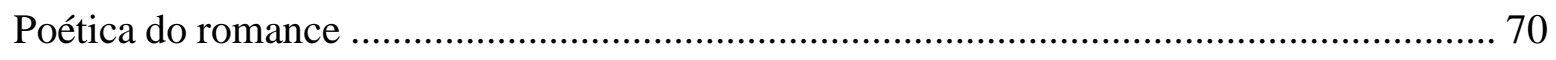

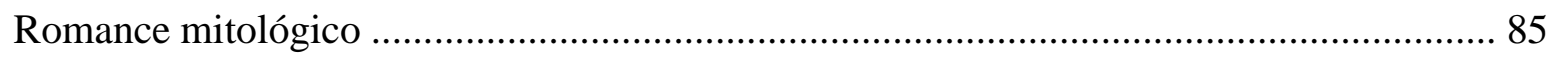

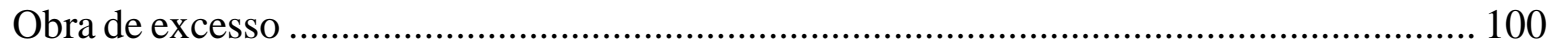

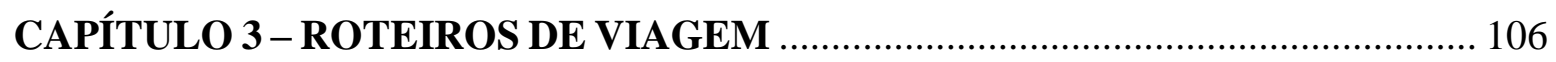

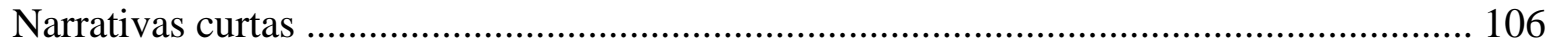

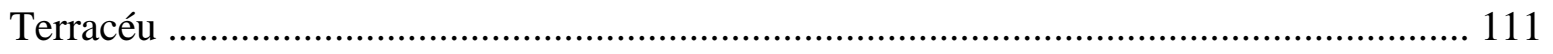

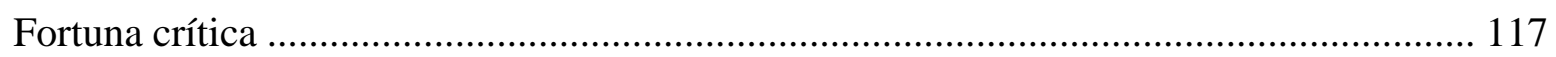



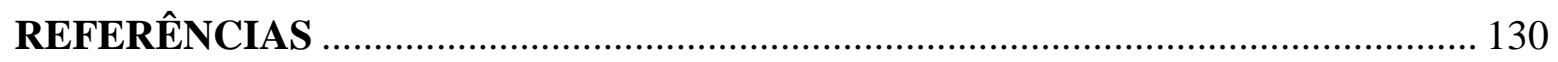

ANEXO - "SOM DO DIVINO MARAVILHOSO" .................................................... 142 
Ora, só há valores do passado. Os valores que apenas podem servir de critérios foram estabelecidos sobre as grandes obras dos nossos pais, dos nossos avós, e muitas vezes mesmo sobre obras mais antigas. São estas obras que, recusadas ontem porque não correspondiam aos valores da época, trouxeram ao mundo significações novas, novos valores, novos critérios, com os quais vivemos hoje.

Alain Robbe-Grillet, Por um novo romance 


\section{INTRODUÇÃO}

\section{UMA OBRA (E UM AUTOR) FORA DO LUGAR}

“Os artistas, dizem, vão mais fundo que os colecionadores de dados e datas.

"Se você quer entender a Rússia, não perca tempo lendo manuais de História.

“Comece logo lendo Os irmãos Karamázvov, de Dostoiévski”. ${ }^{1}$

Assim o poeta Paulo Leminski inicia sua biografia do revolucionário russo Leon Trótsky. Há, nessa abertura, menos demérito ao trabalho do historiador do que um alerta sobre a capacidade do artista em captar o espírito de um tempo. Do mesmo modo que Leminski, não estaríamos sendo imprudentes se propuséssemos a leitura de PanAmérica, ${ }^{2}$ de José Agrippino de Paula, para o entendimento do Brasil da década de 1960.

Esse romance experimental publicado em 1967 é, já há algum tempo, associado às principais manifestações artísticas que surgiram naquele mesmo ano como o filme Terra em transe, de Glauber Rocha, a montagem de $O$ rei da vela, de Oswald de Andrade, pelo Teatro Oficina e algumas das principais canções tropicalistas.

De toda essa produção, o romance de Agrippino permanece a obra menos conhecida. Passado mais de meio século desde sua estreia literária, com outro romance, Lugar público, de 1965, o escritor segue como um autor situado à margem da literatura brasileira.

Marcados pela experimentação formal, seus livros vieram à tona em um período conturbado politicamente e fértil em termos de manifestações artísticas no Brasil e em diversas partes do mundo. Agrippino soube responder a esses estímulos produzindo uma obra representativa daqueles anos. PanAmérica, principalmente, como as demais manifestações citadas, exemplifica o que disse Anatol Rosenfeld ao observar que, em cada fase histórica,

\footnotetext{
${ }^{1}$ LEMINSKI, Paulo. "Trótski, a paixão segundo a revolução”. In: Vida: Cruz e Souza: Bashô: Jesus: Trótski. $2^{a}$ edição. Porto Alegre: Sulina, 1998, p. 174.

${ }^{2}$ Neste trabalho adotaremos a grafia proposta por José Agrippino de Paula: "PanAmérica". Nas citações e referências de outros autores, quando houver divergência, manteremos as grafias por eles utilizadas.
} 
existe um certo Zeitgeist, "um espírito unificador que se comunica a todas as manifestações de culturas em contato, naturalmente com variações nacionais". 3

Além dos romances, Agrippino publicou contos nos anos 1970, mas sua produção não inclui somente literatura. Entre suas principais obras ele escreveu a peça As Nações Unidas, dirigiu o longa-metragem Hitler $I I^{\circ}$ Mundo e, juntamente com Maria Esther Stockler, o espetáculo teatral Rito do amor selvagem. Toda essa produção é marcada pela ruptura com os padrões. Muitas de suas características são recorrentes. Podemos destacar entre elas a fragmentação do material narrativo e a utilização do imaginário da cultura de massa, presentes em diversos momentos da produção do autor. As Nações Unidas e PanAmérica, juntas, podem ser entendidas como mananciais da produção de Agrippino nos anos 1960. Cenas e elementos dessas obras, estudadas em conjunto por sugestão do próprio autor por Evelina Hoisel em Supercaos: os estilhaços da cultura em PanAmérica e Nações Unidas, ${ }^{4}$ aparecem em Rito do Amor Selvagem e em Hitler III ${ }^{\circ}$ Mundo. ${ }^{5}$

Devido à experimentação, a obra de Agrippino é um produto de vanguarda. Nos romances, a ousadia será patente no modo como ele utiliza o narrador, na imaginação delirante e na apropriação de mitos produzidos pela sociedade de massa. Essas duas últimas características são mais discretas em Lugar público, mas serão levadas ao extremo em PanAmérica, romance de difícil assimilação.

Se tomarmos qualquer página de um desses livros veremos que ela representará um desafio ao crítico que, naturalmente, tentará interpretá-las a partir de valores já estabelecidos. Essa é uma das tarefas da crítica, a leitura aos olhos do que já foi feito, como sugere a epígrafe deste trabalho extraída de Alain Robbe-Grillet. Ainda que a obra estudada não siga necessariamente a tradição, haverá nela uma série de elementos que os olhos críticos obrigatoriamente terão de cotejar com o passado e com a qual a obra, queira ou não o autor e do mesmo modo que o crítico, também dialoga. Também faz parte desse trabalho de

\footnotetext{
${ }^{3}$ ROSENFELD, Anatol. "Reflexões sobre o romance moderno". In: Texto/Contexto I. $5^{\text {a }}$ edição. São Paulo: Perspectiva, 1996, p. 75.

${ }^{4}$ Supercaos: os estilhaços da cultura em PanAmérica e Nações Unidas foi defendido como dissertação de mestrado em Literatura Brasileira na Pontifícia Universidade Católica do Rio de Janeiro em 1979.

${ }^{5}$ Felipe Augusto de Moraes propôs que praticamente toda a obra de Agrippino, desde Lugar público até o curtametragem Céu sobre água (de 1977), configuraria uma "arte-soma" (ver Referências). A expressão foi utilizada pelo próprio Agrippino para se referir ao espetáculo Rito do amor selvagem.
} 
interpretação a identificação do novo. O novo de hoje é o velho de amanhã, ainda que, no futuro, mantenha vivos elementos de novidade. É justamente quando atinge esse patamar que obra e autor se mantêm, permanecem. A esse respeito, é famosa uma das definições de clássico dadas pelo escritor italiano Italo Calvino: "um livro que nunca terminou de dizer aquilo que tinha para dizer". 6

Outro fator impossível a um autor, qualquer que seja, é fugir ao seu tempo histórico. Ainda que se isole, ainda que se retraia, ainda que adote hábitos que caíram em desuso ou extravagantes porque antecipadores, o escritor é um ser do seu tempo. Por mais que ofereça, não poderá, nunca, fugir dessa condição. A menos que, como Homero ou como os autores da Bíblia, atinjam a esfera da mitológica. Passados os anos, mesmo que permaneçam instigantes, esses autores integrarão a tradição.

Se romper com a tradição parece fácil, entrar nela e ali permanecer, ainda mais tendo ousado rompê-la, é tarefa das mais difíceis, mas que, por sorte, não cabe ao escritor. A este basta que escreva. Todo o resto vem depois, para lembrarmos uma frase de um grande autor de ruptura, William Faulkner, ao dizer que "o artista está um degrau acima do crítico, pois está escrevendo alguma coisa que porá o crítico em movimento. O crítico está escrevendo alguma coisa que porá todo o mundo em movimento, menos o artista". 7

Faulkner, aliás, estava entre os mais admirados por Agrippino. Em uma entrevista de 1966, ele apontou o autor norte-americano, juntamente com Thomas Wolfe e Franz Kafka, como os "três romancistas estrangeiros deste século de sua preferência". Justificava a escolha dizendo que todos "escreveram sobre o sofrimento humano no século XX" ${ }^{8}$ Nessa mesma entrevista, que nos é importante por dar voz ao romancista justamente no intervalo de publicação de seus dois livros, Agrippino ainda foi instado a citar "três romancistas brasileiros em atividade" e a justificar por que gostava ou não da literatura que eles produziam. A resposta foi: “Jorge Mautner, de quem eu gosto por ser autêntico, urbano e

\footnotetext{
${ }^{6}$ CALVINO, Italo. Por que ler os clássicos. Tradução de Nilson Moulin. São Paulo: Companhia das Letras, 2007, p. 11.

${ }^{7}$ FAULKNER, William. "Entrevista”. In: Os escritores: as históricas entrevistas de Paris Review / [seleção Marcos Maffei]; tradução de Alberto Alexa3ndre Martins, Beth Vieira. São Paulo: Companhia das Letras, 1988, p. 49.

${ }^{8}$ ANTÔNIO, João. "Inquérito: o romance urbano". In: Revista Civilização Brasileira n 7, Rio de Janeiro, Civilização Brasileira, maio de 1966, p. 204.
} 
atual. Guimarães Rosa, aprecio, mas não consigo ver de dentro". ${ }^{9}$ A resposta, curta como todas as demais dadas por Agrippino nessa entrevista, é bastante reveladora. Primeiro porque, ao invés de três autores brasileiros, ele aponta apenas dois. Segundo porque, resguardadas as diferenças, ambos são inovadores. Finalmente porque, ainda que inclua, logo exclui um deles, precisamente João Guimarães Rosa. A declaração, assim, aproxima-o somente de uma obra, a de Mautner, que lhe era contemporânea.

Marcada por intensas transformações políticas e sociais, a década de 1960 viu o florescimento de uma arte de vanguarda em diversas partes do mundo, inclusive no Brasil. Na política, as tensões acumuladas desde o suicídio do presidente Getúlio Vargas, em 1954, em grande parte geradas pelo contexto internacional polarizado entre Estados Unidos e União Soviética, durante a chamada Guerra Fria, culminaram com o golpe de estado de 1964, quando uma ditadura militar se instalou no poder sob o pretexto de impedir as reformas propostas pelo presidente deposto, João Goulart, e reconquistar a estabilidade política, numa situação que se estendeu por vinte e um anos.

No território artístico, especificamente, a manifestação que sobressaiu foi a chamada Arte Pop ou Pop Art. No Brasil, essa tendência se manifestou principalmente no Tropicalismo, por muitos entendido como a manifestação ou a adequação da Pop Art ao contexto nacional. Roberto Schwarz, por exemplo, definiu o movimento tropicalista como "uma variante brasileira e complexa do pop, na qual se conhece um número crescente de músicos, escritores, cineastas, encenadores e pintores de vanguarda". ${ }^{10}$

Esse movimento teve expressão fundamental nas artes plásticas em trabalhos de autores como Hélio Oiticica, Lígia Clark e Antonio Dias, entre outros, e também encontrou repercussão no cinema de Glauber Rocha, notadamente no já citado Terra em transe, e na música popular brasileira, quando cantores e compositores populares e eruditos se reuniram em torno principalmente de Caetano Veloso e Gilberto Gil, na vertente do tropicalismo que ficou mais conhecida.

\footnotetext{
${ }^{9}$ Idem, ibidem, p. 200.

${ }^{10}$ SCHWARZ, Roberto. “Cultura e política, 1964-69”. In: O pai de família e outros ensaios. São Paulo, Companhia das letras, 2008, p. 84.
} 
Foi justamente a partir desse lugar, a década de 1960, que Agrippino criou uma obra que o marcaria como artista e que, num revés, marcaria também o período. Caetano Veloso, amigo e admirador confesso de Agrippino, sempre que pôde, procurou valorizar o trabalho e as ideias do autor citando-o em letras de música, artigos e entrevistas. ${ }^{11}$ Tanto, que acabou se tornando um de seus melhores retratistas. ${ }^{12}$ No prefácio à terceira edição de PanAmérica, ele escreveu:

[...] José Agrippino de Paula vivenciou os conteúdos da vida do final do século passado com tanta frieza e tanta paixão que talvez não haja no mundo nenhuma obra literária contemporânea de seu PanAmérica que lhe possa fazer face. $[\ldots]^{13}$

O paradoxo, "frieza e paixão", marca a trajetória de Agrippino. Como não poderia deixar de ser, ele fica patente em sua obra. Isso porque o autor foi, durante os anos 1960 principalmente, um homem que, imerso no tecido social, encontrava um distanciamento para observar a sociedade. Um envolvimento profundo o filiava àquela geração, mas, ao mesmo tempo, um distanciamento crítico com que a observava o afastava. Talvez por isso seu caso seja tão singular. Apesar de elementos reconhecíveis, nada mais diverso do que Agrippino da descrição feita por Antonio Risério sobre as características dessa geração.

[...] Para falar em termos semicaricaturais, o desbundado não estava preocupado em mudar o regime político, mas em ficar na dele, em paz, queimando seu charo e ouvindo Rolling Stones. Antes que alterar o sistema

\footnotetext{
${ }^{11}$ Em 1976, juntamente com Gilberto Gil, Caetano musicou o trecho inicial do quinto capítulo de PanAmérica. O resultado da parceria é a canção "Eu e ela estávamos ali encostados na parede", do LP Doces bárbaros - ao vivo. Na letra de "Gente", do LP Bicho, de 1977, o nome de Agrippino é citado ao lado de artistas amigos do cantor baiano. No ano seguinte, um dos maiores clássicos de Caetano, a canção "Sampa", do LP Muito (dentro da estrela azulada), faz uma referência direta à obra seminal de Agrippino no verso: "Panaméricas de Áfricas utópicas, túmulo do samba, mas possível novo quilombo de Zumbi".

${ }^{12}$ Roberto Schwarz disse que "Caetano possui como poucos a capacidade de caracterizar artistas e obras". (SCWARZ, 2012, p. 73)

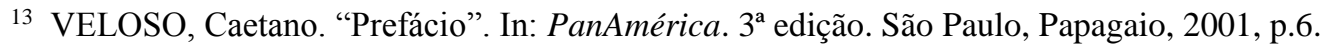


de poder, ele pretendia, pela transformação interior e da conduta cotidiana, 'mudar a vida', quem sabe construindo-se como um novo ser de uma Nova Era, espécie de amostra grátis do futuro. Jerry Rubin [...] dizia então que 'revolução' não era a crença à qual você aderira, a 'organização' a que você pertencia ou o partido em que votava, mas sim o que você fazia durante todo o dia - o seu modo de viver. Indo além, Luiz Carlos Maciel morou numa comunidade, Rogério Duarte foi monge budista, Roberto Pinho montou a Guariroba, a 'refazenda' da canção de Gilberto Gil, prevendo desde uma economia de subsistência até contatos com seres extraterrestres. [...] ${ }^{14}$

Alguns dos citados nesse trecho, como Gilberto Gil, eram próximos de Agrippino. E Rogério Duarte, como Caetano Veloso, era seu amigo. Foi nesse contexto citado por Risério que, entre o fim dos anos 1960 e o começo dos anos 1970, o Brasil, seguindo um movimento iniciado nos países desenvolvidos tendo os Estados Unidos como centro irradiador, passou a responder aos estímulos da chamada contracultura, apontado pelo historiador norteamericano Theodore Roszak. Era a época do "desbunde”, que, em nosso país, coincidiu com os anos mais violentos da ditadura militar. Antônio Risério situa o movimento: "Na passagem da década de 1960 para a de 1970, os segmentos mais inquietos da juventude urbana brasileira se distribuíram em duas vertentes radicais: a esquerda e o movimento contracultural". ${ }^{15}$

Essas vertentes não necessariamente se opunham, mas, tendo instrumentos de ação e reações diversas diante da realidade que se apresentava, seguiam caminhos completamente diferentes. Enquanto a esquerda se caracterizava pela militância que, no extremo, levava a ações armadas, os desbundados procuravam refugiar-se em novas formas de viver que tinham o seu lado mais radical no abandono completo da realidade urbana e burguesa. Naquele contexto de estado de exceção, em que a defesa dos ideais democráticos era uma exigência, não era difícil vê-los todos como alienados. Apontando outro aspecto da alienação, Risério comenta a postura dos jovens de então:

\footnotetext{
${ }^{14}$ RISÉRIO, Antonio. "Duas ou três coisas sobre a contracultura no Brasil”. In: Anos 70: trajetórias. São Paulo: Iluminuras, Itaú cultural, 2005, p. 25-26.

${ }^{15}$ Idem, ibidem, p. 27.
} 
[...] A contracultura, revivendo o romantismo literário dos séculos XVIII e XIX, pregou o seu 'retorno à natureza'. Diante da alienação trabalhista e do pragmatismo cientificista, ergueu os valores da contemplação e da harmonia. Era como se os jovens do mundo ocidental, especialmente os hippies, estivessem redescobrindo o milagre diário da natureza. Celebrava-se, na verdade, o mito da pureza do ser humano em contato com o mundo natural. Um ambientalismo místico, em suma, integrando a novíssima fantasia utópica da juventude mundial. ${ }^{16}$

Ainda que não seja a função deste trabalho analisar a vida de Agrippino, é interessante notar como há pontos em que sua produção se aproxima de modo quase indissociável de sua trajetória pessoal.

José Agrippino de Paula e Silva nasceu no dia 13 de junho de 1937 na cidade de São Paulo. ${ }^{17}$ Filho do professor e advogado Oscavo de Paula e Silva e da professora Claudemira Vasconcellos, viveu seus primeiros anos em Itu, no interior do estado, onde os pais trabalhavam. Em 1942 a família voltou a viver na capital. O segundo e último filho do casal, Guilherme, nasceu dois anos depois, em 1944.

Agrippino fez os primeiros estudos no Ginásio do Estado no bairro da Lapa, onde morava. Formou-se no curso científico em 1955 e, no ano seguinte, ingressou na Faculdade de Arquitetura e Urbanismo da Universidade de São Paulo. A morte do pai em 1957 provocou um grande abalo na família. Dois anos depois, em 1959, Agrippino transferiu-se para a Faculdade Nacional de Arquitetura, da Universidade do Brasil, no Rio de Janeiro (atual FAU da Universidade Federal do Rio de Janeiro).

Nesse período carioca começou a se envolver com teatro. Estudou com o diretor italiano Gianni Ratto e, na universidade, adaptou, para o Teatro universitário do Rio de Janeiro, o romance Crime e castigo, de Fiódor Dostoiévski, primeiro registro de seu trabalho

\footnotetext{
${ }^{16}$ Idem, ibidem.

${ }^{17}$ Salvo quando indicadas, as informações biográficas deste trabalho foram todas extraídas de nosso estudo anterior, O homem hibernado, a vida de José Agrippino de Paula (ver Referências).
} 
literário, de 1961. Além de interpretar o protagonista Raskólnikov, Agrippino foi o responsável pelo cenário e direção da peça montada por um curto período no teatro de arena da própria faculdade, no bairro da Urca.

Em 1962, formou-se arquiteto. Sem interesse pela profissão, trabalhou durante um curto período na adaptação de clássicos para a televisão, ao mesmo tempo em que escrevia o livro que viria a ser Lugar público. Há pelo menos um registro desse período, a transposição de A letra escarlate, de Nathaniel Howthorne, para o programa Grande teatro Phillips. ${ }^{18}$

Sem condições financeiras de permanecer no Rio, Agrippino voltou a São Paulo em 1965, ano em que publicou Lugar público. Logo, conheceu a bailarina e coreógrafa Maria Esther Stockler, com quem passou a viver. O encontro resultaria em uma grande parceria artística.

José Agrippino produziu em uma escala meteórica aproximadamente durante cinco anos, entre 1965 e 1969. Em 1966 escreveu a peça As Nações Unidas que, além de textos, trazia indicações de movimentos cênicos e ações puramente visuais. No ano seguinte, em 1967, publicou seu segundo romance, PanAmérica, definido pelo autor como "epopeia" e apresentado pelo crítico Mário Schenberg como "uma contribuição de importância internacional para a utilização literária de alguns dos mitos fundamentais contemporâneos". ${ }^{19}$

Nessa mesma época, fundou com a mulher e outros artistas, o Sonda, um misto de

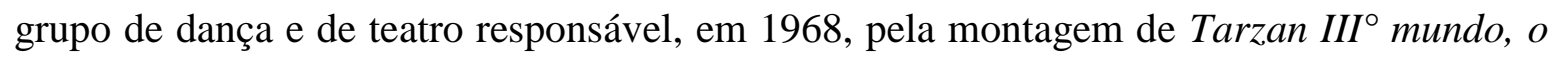
mustang hibernado. ${ }^{20} \mathrm{~A}$ peça tinha cenas concebidas por diversos artistas, entre eles José Agrippino. A direção-geral coube a Maria Esther. Apresentada no Primeiro Festival de Dança de São Paulo, Tarzan foi a primeira experiência a misturar dança e dramaturgia realizada no Brasil.

Logo depois, no Rio de Janeiro, o casal produziu, em parceria com o grupo de rock Os Mutantes, o espetáculo O planeta dos Mutantes. O roteiro era de Agrippino e dos membros da banda e a direção novamente de Maria Esther.

\footnotetext{
${ }^{18}$ Edwaldo Cafezeiro nos contou que o autor também teria adaptado o conto "Plebiscito", de Arthur Azevedo. No entanto, não encontramos nenhuma referência a esse texto (entrevista ao autor).

${ }^{19}$ SCHENBERG, Mario. “Apresentação”. In: PanAmérica. Rio de Janeiro, Tridente, julho de 1967.

${ }^{20}$ Irlainy Regina Madazzio dedicou um estudo ao grupo intitulado O voo da borboleta, a obra cênica de José Agrippino de Paula e Maria Esther Stockler (ver Referências).
} 
Ainda em 1968, Agrippino dirigiu o filme Hitler $I I I^{\circ}$ mundo, obra experimental que tem no elenco, além de membros do grupo Sonda, atores consagrados como Ruth Escobar, Eugênio Kusnet e Jô Soares.

Também é dessa época a filmagem, inconclusa, da peça $O$ balcão, escrita pelo francês Jean Genet e dirigida pelo encenador franco-argentino Victor Garcia no Teatro Ruth Escobar, em São Paulo. Ainda que às vezes seja atribuída a Agrippino, não há documento que comprove que ele trabalhou na filmagem que, ao que parece, foi encabeçada por Jorge Bodanzki, diretor de fotografia de Hitler e amigo de Agrippino.

Entre 1969 e 1970, o Sonda produziu e montou, com direção de Maria Esther e de Agrippino, o espetáculo Rito do Amor Selvagem, primeiro em São Paulo e depois no Rio de Janeiro. ${ }^{21}$ Como em Tarzan, a montagem foi definida por Agrippino como "mixagem" de dança e teatro e teve grande sucesso de público e crítica.

No começo dos anos 1970, uma violenta batida policial na casa em que o casal morava no bairro de Perdizes, em São Paulo, abalou profundamente o escritor. Amigos próximos dizem que ele nunca mais foi o mesmo depois do episódio. Então, por "sugestão" dos militares, Agrippino deixou o Brasil. Em 1971, ele viajou juntamente com Maria Esther Stockler, com um irmão dela e o ator José Ramalho, membro do Sonda, para a costa atlântica do continente africano, onde, com uma câmera Super-8, produziu diversos curtasmetragens. ${ }^{22}$ Durante o exílio de quase três anos, Agrippino e Esther viveram em solo africano e também viajaram pela Europa. Agrippino ainda ficou uma temporada nos Estados Unidos e Canadá.

Maria Esther e Agrippino retornaram ao Brasil em 1973, indo morar na Bahia. O curta Céu sobre água, realizado na praia de Arembepe, em Salvador, foi o último filme do autor. Em 1974 nasceu a primeira filha do casal, chamada Manhã, que morreria em um acidente de carro em 1994 (Agrippino tinha outra menina, Chara, nascida em 1972, fruto de outro

\footnotetext{
${ }^{21}$ Jorge Bodanzki, diretor de fotografia de Hitler, fotografou e filmou o Rito do amor selvagem. Hoje, algumas dessas fotos estão conservadas no acervo da Prefeitura no Centro Cultural São Paulo, mas o registro audiovisual se perdeu (entrevista ao autor).

${ }^{22}$ Alguns desses trabalhos, juntamente com o curta Céu sobre água, foram reunidos em um box lançado pelo Sesc em 2012 chamado Exu 7 eencruzilhadas, que também traz um CD com o mesmo nome contendo gravações de seções de improviso musical de Agrippino registradas em São Paulo no começo dos anos 1970.
} 
relacionamento). Logo depois o casal se separou. Na praia soteropolitana da Boca do Rio, Agrippino produziu pelo menos um espetáculo com crianças membros de comunidades candomblé, $O$ espírito menino do planeta Terra. Ainda naquela década, publicou textos em revistas: "Roteiro de viagem do diário oficial das drogas do Ocidente", "Na alameda dos baobás, "A cigana prateada da lua" e "Tribo do mar e do ar sagrado", além de tentar, em vão, voltar a filmar.

No final de 1979, com problemas de saúde, Agrippino voltou a morar com a mãe em São Paulo e, a partir de 1982, depois de surtos e de uma internação que lhe rendeu o diagnóstico de esquizofrênico, mãe e filho passam a viver na cidade de Embu, hoje Embu das Artes, na região metropolitana de São Paulo. Claudemira morreu em 1988, pouco depois do relançamento de PanAmérica e de uma mostra com exibições de filmes de Agrippino realizada em São Paulo, à qual o artista não compareceu. Nesse mesmo ano, a videoartista Lucila Meirelles codirigiu com Walter Silveira o documentário poético Sinfonia PanAmérica.

O período vivido em Embu foi marcado pelo isolamento de Agrippino do convívio social, algo que vinha se desenvolvendo desde o fim dos anos 1970. Ainda assim, ele permaneceu escrevendo. Em 2001, foi publicada uma terceira edição de PanAmérica. Alguns anos depois, a psicanalista Miriam Chnaiderman tentou fazer Agrippino voltar a filmar, mas o projeto não foi adiante. O resultado dessa tentativa frustrada é o documentário Passeios no recanto silvestre, de 2006, cujo título foi sugerido pelo próprio Agrippino. Nesse mesmo ano, 39 depois da edição original, Lugar público foi relançado.

Com a saúde debilitada, Agrippino sofreu um infarto fulminante e foi encontrado morto em casa pelo irmão no dia 4 de julho de 2007, poucos dias antes de completar 70 anos. Foi enterrado juntamente com os pais no cemitério da Lapa, em São Paulo.

Não é função deste estudo associar a "loucura clínica" à produção estética ou à "loucura cultural" de Agrippino, mas é inegável que a irracionalidade se manifesta em sua 
obra. Aqui, novamente lembramos de Caetano Veloso, que chamou Agrippino de "um irracionalista radical". ${ }^{23}$

Como Caetano e Leminski - e também Torquato Neto, Glauber Rocha e Hélio Oiticica -, Agrippino pertenceu a uma geração de artistas associados à loucura muitas vezes porque ousaram romper com padrões estéticos, artísticos, sociais ou comportamentais. Antes de ser clínica, ela era uma postura que tinha na base a negação da racionalidade, conforme explica o sociólogo Cláudio Novaes Pinto Coelho:

Ao reduzir a racionalidade à racionalização autoritária, a contracultura colocava a negação da racionalidade enquanto tal como a única possibilidade de questionamento da sociedade vigente; daí a adoção da 'loucura'. Nas palavras de Heloísa Buarque de Hollanda, analisando a contracultura, como seu "[...] empenho na procura de uma forma nova de pensar o mundo, a loucura passa a ser vista como uma perspectiva capaz de romper com a lógica racionalizante da direita e da esquerda' (Hollanda, 69)". 24

Pinto Coelho e Heloísa Buarque de Hollanda estavam tratando do aspecto político da loucura. O sociólogo vai além. Ao tratar das relações entre a contracultura e loucura, cita o poeta tropicalista Torquato Neto:

A vida e a obra do poeta e jornalista Torquato Neto apresentam de forma vigorosa as diferentes dimensões da relação entre a contracultura e a 'loucura'. Em Os últimos dias de paupéria, livro póstumo que reúne poesias, artigos publicados no jornal Última Hora e o diário escrito quando se encontrava internado num hospício, a loucura aparece ora como algo atribuído pelo outro com finalidade de repressão e controle, ora como uma

\footnotetext{
${ }^{23}$ VELOSO, Caetano. "Um irracionalista radical". Folha de S. Paulo, São Paulo, 16 dez 1984. Em Verdade tropical, Caetano diz que, em conversas, "Agrippino exemplificava a força do chamado irracionalismo perante os espasmos do pensamento sistemático". (VELOSO, 1997, p. 108)

${ }^{24}$ COELHO, Cláudio Novaes Pinto. "A contracultura: o outro lado da modernização autoritária”. In: Anos 70: trajetórias. São Paulo: Iluminuras, Itaú cultural, 2005, p. 41.
} 
forma de libertação, ora como uma situação que precisa ser superada para se poder sobreviver. ${ }^{25}$

Em Agrippino, a loucura se manifestará como questionamento em Lugar público e como delírio em PanAmérica, obra que foge completamente da razão e que, por isso, como veremos, impõe-se como um desafio para a crítica. Talvez seja justamente o delírio o elemento que aproxima esse livro do universo dos mitos. E, em Agrippino, interessam, sobretudo, os mitos.

Restrito ao território da literatura, este trabalho pretende analisar a prosa de ficção de José Agrippino de Paula, sobretudo esses romances publicados a uma distância de dois anos. Acreditamos que tais obras, por nós entendidas como uma produção deslocada, fora do lugar em relação à prosa de ficção brasileira dos anos 1960, são, paradoxalmente, um retrato desse período, mas extrapolam seus limites devido ao alto grau de informação que ainda trazem, falando, como veremos, a uma nova geração de leitores e escritores.

O primeiro capítulo é dedicado a Lugar público, onde o retrato tende para o psicológico, para a esfera do individual. Já em PanAmérica, que recebe nossa atenção no segundo capítulo, o retrato tenderá para o alegórico e para o coletivo. Em muitos aspectos como, por exemplo, no uso da descrição como elemento de composição fundamental, os livros se aproximam, o que também ocorrerá com algumas características das narrativas curtas. Enquanto o Lugar público se apropria de inovações do romance de vanguarda, muitas delas experimentadas pelo chamado Novo Romance Francês, PanAmérica aprofunda essas experimentações inserindo-se na esfera mitológica com um trabalho de radicalização da linguagem que faz do livro até hoje um fato estético singular.

No terceiro capítulo nos deteremos nas narrativas publicadas por Agrippino nos anos 1970, bem como a seus projetos de romances inacabados e à recepção crítica de seus livros, buscando uma síntese de sua produção. O que pretendemos não é demonstrar a exclusividade de José Agrippino de Paula, mas sim ressaltar as particularidades de sua literatura.

\footnotetext{
${ }^{25}$ Idem, ibidem, p. 43.
} 


\section{CAPÍTULO 1}

\section{LUGAR PÚBLICO, UM ROMANCE NA SUPERFÍCIE DO POSSÍVEL}

Ele acorda e recria o mito da existência.

Lugar público

\section{Romance de superfície}

Há um lugar não definido em Lugar público. Esse lugar não é físico, ainda que boa parte da narrativa se desenrole no espaço das grandes cidades. Esse lugar não é interiorizado, ainda que o narrador, ou os narradores, como veremos, olhe para si numa tentativa de perscrutar seu interior. Podemos tentar chegar a esse lugar por exclusão, mas nessa operação corremos o risco de, vasculhadas todas as camadas, nos depararmos com o vazio, com o lugar do nada.

Composto por centenas de relatos protagonizados por personagens que erram pelos dois principais centros urbanos do país, Lugar público é um romance que convida a pensar o espaço. A delimitação geográfica, no entanto, não tem tanta importância na narrativa. O que interessa é a natureza da interação dos seres com o meio a que estão sujeitos. Essa relação é sempre precária, insuficiente, falha e incômoda. Entre esses seres errantes, destaca-se a figura do narrador-protagonista.

Ele não tem nome. É identificado apenas como um "Eu" e escreve o que podemos supor ser um diário sem marcadores temporais, onde faz centenas de descrições de acontecimentos corriqueiros, cenas observadas a esmo, cenas imaginadas, seus dilemas e lembranças. Diante dessas descrições, percebermos que ele não é capaz de se transformar ou de transformar a realidade em que está inserido. Ele é quase incapaz de interagir com essa realidade. Sua atitude diante da existência é de apatia, inércia, inaptidão e inadequação. Sem o envolvimento transformador, ele permanece na superfície da realidade da narrativa. $\mathrm{O}$ 
efeito é obtido pelo que chamaremos de nivelamento do material narrado. Lugar público compreende aquilo que Roland Barthes chamou de "romance em superfície". ${ }^{26}$

Há uma frase repetida no livro que chama a atenção por funcionar como uma síntese de toda a obra. Curta, de aparência simples, como de resto são todas as construções do romance, essa enunciação parece condensar alguns dos principais aspectos que tentaremos desenvolver a respeito da narrativa.

Meu pai limpava, todas as manhãs, batendo no colchão, a pele seca que despregava de seu corpo durante a noite. ${ }^{27}$

Estão aí figura do pai, vista com distanciamento pelo narrador, a doença, a fragmentação, nos pedaços que se desprendem do corpo, e a epiderme, a superfície, representada por uma pele seca e morta. Todos esses elementos: o pai, a fragmentação e a superfície serão úteis na nossa análise. A frase compõe um dos inúmeros blocos da narrativa. Quando surge em um parágrafo isolado, ela não tem, como os demais, qualquer relação com o que foi dito antes e tampouco terá como o que virá depois. Além disso, ela ainda será repetida, o que também ocorre com outras cenas do livro.

A rigor, Lugar público não tem uma trama unívoca. Não há um enredo progressivo que culmine em um desfecho. O que há são fios de histórias que não se enovelam, mas formam um emaranhado uniforme com temas que podem ser lidos no mais das vezes como autônomos e superpostos. Nisso, o romance se diferencia bastante de uma narrativa convencional em que, segundo Tzvetan Todorov: "a história raramente é simples: contém frequentemente muitos 'fios' e é apenas a partir de um certo momento que estes fios se reúnem". ${ }^{28}$ No emaranhado de Lugar público, na diversidade de relatos que compõe a narrativa, essa reunião não terá lugar. E ela nem teria sentido. Os fios permanecem soltos, mas nem por isso não configuram um sentido. $\mathrm{O}$ narrador vai da descrição distanciada de

\footnotetext{
${ }^{26}$ BARTHES, Roland. "Literatura objetiva". In: Crítica e verdade. Tradução de Leyla Perrone-Moisés. São Paulo, Perspectiva, 2013a, p. 92.

27 PAULA, José Agrippino de. Lugar público. Civilização Brasileira, Rio de Janeiro, 1965, p. 45, 116, 193, 212.

${ }^{28}$ TODOROV, Tzvetan. "As categorias da narrativa literária”. In: Análise estrutural da narrativa. Tradução de Maria Zélia Barbosa Pinto. Vozes: Petrópolis, RJ, 1971, p. 215.
} 
cenas urbanas até cenas em que participa com companheiros que se encontram na mesma situação precária em que ele vive.

O conflito principal, o do narrador, é o de um jovem desajustado que vive o dilema de enfrentar a vida adulta. Sem alternativa, ele fornece relatos cujos significados parecem não ir além da aparência. Ele recorda de situações familiares e descreve hábitos e acontecimentos cotidianos supérfluos e pueris. As lembranças, no entanto, e podemos sentilo pela frase sobre o pai doente, não cumprem uma função de autoanálise. O narrador, quando recorre à memória, não busca no passado o acontecimento que o marcou a ponto de, no presente da narrativa, entender sua situação. Não há relação de causa e efeito e, se houver, não cabe ao narrador estabelecer esses nexos. A memória, quando aparece, é descrita com o mesmo distanciamento de uma cena observada na rua. A lembrança individual não tem mais peso do que um acontecimento qualquer. Os acontecimentos estariam assim nivelados. Lugar público seria, portanto, um romance de tensão superficial.

Além disso, a narrativa apresenta diálogos como no teatro, com falas e rubricas, e o acontecimento moderno como o decolar de um avião, por exemplo, visto como um acontecimento fantástico. ${ }^{29}$ Num extremo desse mosaico narrativo, são apresentados relatos extraordinários, sem qualquer relação com a verossimilhança.

É na profusão dessas histórias, em sua diversidade, que o livro se realiza como todo uno e coerente. Ao mesmo tempo em que dão à obra uma aparência fragmentária, os relatos garantem-lhe a unidade, que será reforçada pela repetição, pelo espaço em que as personagens circulam, pela presença de aparelhos e objetos por vezes alçados à condição de personagens, enfim, pelos acontecimentos que vão se desenrolar ao longo da narrativa.

Há nesse jogo entre fragmentação e unidade um paradoxo para o qual concorre a estrutura do livro. Não há, nessa obra, uma divisão em partes ou capítulos. Tampouco há numeração para os fragmentos ou marcadores como espaços ou páginas em branco entre os parágrafos. O escritor dispõe o material de modo ininterrupto: os parágrafos funcionam como blocos autônomos agrupados em sequência, e os relatos são apresentados de modo contínuo.

\footnotetext{
${ }^{29}$ Não nos ocuparemos, ao longo deste estudo, em enquadrar os textos de Agrippino dentro de definições dadas sobre literatura fantástica, surrealismo, realismo maravilhoso etc. Procederemos dessa maneira por acreditarmos que, em seus escritos, sobretudo no romance, o autor operou com tanta liberdade que qualquer definição seria limitadora. Por isso, utilizamos indiscriminadamente expressões como "fantástico", "extraordinário", "maravilhoso", "suprarreal” etc.
} 
Ou seja, os parágrafos se sucedem como em qualquer texto, mas trazem conteúdos descontínuos, estranhos ao que veio antes e ao que virá na sequência. Vejamos um exemplo:

Ela disse que deveria ir embora. Levantei-me e seguimos em direção à avenida. Ela sentou no banco de pedra e retirou a sandália. Limpava com as mãos a areia do pé. Eu senti o desejo de limpar a areia de seu pé, mas existia um casal ao lado e ela calçou a sandália, colocou um cigarro na boca e atravessamos a avenida. Atravessamos a outra avenida.

A buzina de um carro que passa... o zumbido do motor desaparece. Fechou a porta. Entrou no banheiro. Quem? A mulher? Não deve ser a mulher, ela arrasta os chinelos.

Insatisfação completa. Escrita inconsciente. Falta ânimo. Deveria ir embora. A incapacidade de transportar uma parte de minha energia em trabalho remunerado. Participo ativamente do trabalho, o que significa dizer violência interna.

No final da festa por não ter onde dormir César foi apara a casa de um dos sujeitos do PC. O sujeito advertiu que alguns dias, um pederasta, amigo do sujeito, dormia no apartamento. César disse que não havia problema; mas o sujeito advertiu que se ele, o pederasta, chegasse durante a noite, César deveria acordá-lo. César disse que acordou durante a noite com o pederasta sentado em sua cama e sorrindo. O pederasta perguntou: "Ele bebeu?" César olhou para o lado e disse: "Ele está dormindo. Bebeu um pouco". O pederasta continuou sorrindo e César dormiu. No outro dia, acordou com o pederasta dormindo ao seu lado, com a cabeça encostada no seu ombro. César levantou-se, foi até o banheiro e, quando ia saindo, o pederasta perguntou: "Você já vai?" César respondeu: "Vou”. César achou estranho que o comunista tivesse uma vida pessoal tão confusa e fosse amante de um pederasta. ${ }^{30}$

Nesse trecho, transcrito sem qualquer interferência ou omissão da nossa parte, notamos dois narradores diferentes, um protagonista e um observador. A irrupção das

\footnotetext{
${ }^{30}$ PAULA, José Agrippino de. Lugar público. Civilização Brasileira, Rio de Janeiro, 1965, p. 140-141.
} 
histórias, uma sobrepondo-se à outra, a cisão da figura do narrador entre a primeira e a terceira pessoa e a descrição como recurso fundamental para a apresentação dos acontecimentos colaboram para nivelar o conteúdo do material narrado e reforçar a sensação de desalento e apatia que emana de todo o livro.

A opção pela divisão entre um narrador-protagonista e um narrador-observador colabora para criar um incômodo na narrativa. O narrador em terceira pessoa viverá inúmeros acontecimentos que se assemelham aos narrados pelo narrador-protagonista. É isso o que nos leva a supor se tratar do mesmo indivíduo, ainda que não haja nada na obra que o confirme. Podemos, então, inferir que "Eu" e "Ele" sejam as duas maneiras como esse indivíduo se percebe, vendo-se ora de dentro, ora de fora. Os diferentes focos narrativos, portanto, não configuram diferentes vozes para o narrador. Não são diferentes personagens que narram. $\mathrm{O}$ que há são diferentes instâncias para um mesmo narrador.

Essa cisão remonta à fragmentação do indivíduo característica da psicologia do homem moderno. O narrador de Lugar público corresponde à fragmentação apontada desde a virada dos séculos XIX para o XX, quando a experiência humana passou a sentir os efeitos da técnica e dos progressos permitidos pela evolução industrial. Eliane Robert Moraes contextualiza esse momento, revelando os impactos da crise do humanismo sobre a consciência e a cultura ocidentais.

Fragmentar, decompor, dispersar: essas palavras se encontram na base de qualquer definição do "espírito moderno"'. Entre a década de 1870 e o início da Segunda Guerra Mundial, a Europa assistiu a uma crise profunda no humanismo ocidental, com radical impacto sobre a política, a moral e a estética. Os homens da época vivenciaram uma complexa transformação da mentalidade europeia, marcada sobretudo por um sentimento de instabilidade.

De início, diz McFarlane, a ênfase recaiu sobre a fragmentação, o rompimento e a progressiva desintegração dos sistemas meticulosamente elaborados durante o século XIX: as leis gerais que diziam respeito à totalidade da vida, implicando os comportamentos, dissolviam-se diante da dispersão que o mundo moderno apresentava. A cultura tradicional sofria um colapso e as tentativas que se seguiram a esse período inicial, no sentido de 
recompor as relações com vistas a uma nova ordem, só fizeram reiterar o forte sentimento de desordem e caos que se instalara na consciência europeia. Nenhum inventário do universo parecia estar à altura do fenômeno de seu estilhaçamento. $^{31}$

O sentimento de desordem e caos seria domado apenas pelos regimes totalitários, que acabaram resultando nas duas grandes guerras. Passado esse período de desestabilização e incerteza, com o fim da Segunda Guerra surge a necessidade de reorganização do mundo. É nesse contexto que Theodor W. Adorno escreve um ensaio sobre a crise do narrador contemporâneo em que diz: "o que se desintegrou foi a identidade da experiência, a vida articulada e em si mesma contínua, que só a postura do narrador permite". ${ }^{32}$ A partir dessa ruptura a ficção exige novas estruturas. Com a desintegração da identidade dessa experiência, o narrador precisa ocupar outro lugar.

De fato, os romances que hoje contam, aqueles em que a subjetividade liberada é levada por sua própria força de gravidade a converter-se em seu contrário, assemelham-se a epopeias negativas. São testemunhas de uma condição na qual o indivíduo liquida a si mesmo, convergindo com a situação pré-individual no modo como esta um dia pareceu endossar o mundo pleno de sentido. ${ }^{33}$

A liquidação do indivíduo e a situação pré-individual parecem ser justificadas, em Lugar público, pela opção por um narrador cindido. Diante da desintegração, da desarticulação, o romance configura um narrador descontínuo que não apenas produz relatos desarticulados como o faz a partir de diferentes focos narrativos, ainda que o ponto de vista seja o mesmo.

\footnotetext{
${ }^{31}$ MORAES, Eliane Robert. O corpo impossível a decomposição da figura humana: de Lautréamont a Bataille. São Paulo: Iluminuras, 2002, p. 56.

32 ADORNO, Theodor W. "Posição do narrador no romance contemporâneo". In: Notas de literatura I. Tradução de Jorge de Almeida. São Paulo, Editora 34, 2003, p. 56.

${ }^{33}$ Idem, ibidem, p. 62.
} 
A primeira edição de Lugar público, de 1965, destacava a associação da obra com o Novo Romance Francês. Um texto na quarta capa dizia: "Uma obra que introduz a nossa ficção no plano do nouveau roman, sem jamais abandonar, no entanto, as coordenadas brasileiras que a inspiraram". ${ }^{34}$ A orelha, escrita por Carlos Heitor Cony, falava da "economia sintática" e da "construção sincopada, em blocos", do romance, além de citar um ensaio de Robbe-Grillet e autores como Campos de Carvalho, Henry Miller e Jean-Paul Sartre, aproximando-os, assim, de Agrippino. ${ }^{35}$

O Novo Romance Francês englobou autores diversos como Nathalie Sarraute, Claude Simon, Samuel Beckett e Jean-Marie Gustave Le Clézio, entre outros, surgidos aproximadamente entre as décadas de 1940 e 1960 e responsáveis por obras com características experimentais e inovadoras. ${ }^{36}$ Alain Robbe-Grillet, um dos principais ficcionistas e também teórico do movimento, diz que o Novo Romance

[...] não codificou qualquer lei. O que faz que não se trate de uma escola literária no sentido estrito do termo. Somos os primeiros a saber que há entre as nossas obras respectivas - a de Claude Simon e a minha, por exemplo diferenças consideráveis, e pensamos que está muito bem assim. Que interesse pode haver para o que ambos escrevemos, se escrevêssemos a mesma coisa? ${ }^{37}$

Depois, para justificar a associação dos autores, ele insiste no questionamento:

[...] À volta de que se agruparam sempre os artistas, senão da recusa às formas obsoletas que se procurava impor-lhes? As formas vivem e morrem, pelo que é preciso renová-las continuamente: a composição romanesca do tipo século

\footnotetext{
${ }^{34}$ PAULA, José Agrippino de. Lugar público. Rio de Janeiro, Civilização Brasileira, 1965.

35 CONY, Carlos Heitor. “Apresentação”. In: Lugar público. Rio de Janeiro, Civilização Brasileira, 1965.

${ }^{36}$ Antonio Candido apontou Clarice Lispector como "uma desconhecida precursora" do "nouveau roman" no Brasil. (CANDIDO, 1999, p. 210)

${ }^{37}$ ROBBE-GRILLET, Alain. "Novo romance, homem novo". In: Por um novo romance. Tradução de Cristóvão Santos. Lisboa, Publicações Europa América, 1965, p. 144.
} 
XIX, que era a própria vida há cem anos, já não é senão uma fórmula vazia, apenas útil para fastidiosas paródias. [...] ${ }^{38}$

O raciocínio expõe algumas das características generalizadoras do movimento como, por exemplo, o fato de não constituir escola literária, a recusa às formas do passado e a necessidade de renovação. Leyla Perrone-Moisés, uma das primeiras críticas brasileiras a se deter sobre o tema, disse que

O Novo Romance Francês não constitui uma “escola” literária, assim como não se pode dizer que seus participantes formem um grupo - já que um grupo implica programa comum, reuniões, etc. Somente algumas coincidências nas obras de determinados romancistas fizeram com que, logo após a $2^{\text {a }}$ Guerra Mundial, jornalistas e críticos começassem a falar de uma nova "escola" dentro do romance francês. O espírito simplificador do jornalismo, a atração da novidade e o esnobismo foram as causas do estabelecimento deste equívoco. Na verdade, a obra de cada um dos romancistas involuntariamente rotulados de "novos romancistas" deve ser examinada à parte, pois cada um deles oferece problemas particulares. E somente algumas semelhanças nestas obras justificam que as analisemos lado a lado e vejamos nelas uma tendência do romance francês atual. ${ }^{39}$

Seguindo esse entendimento, Sandra Nitrini observou que "a inexistência de uma Escola do Novo Romance não exclui o parentesco de pesquisas formais enveredadas pelos diversos novos romancistas, mesmo que originalmente tenham sido bastante diferentes". ${ }^{40}$

Para este estudo, discutir se esse grupo constituiu uma escola literária é menos relevante e improdutivo do que apontar, na obra de Agrippino, procedimentos comuns a alguns desses romancistas.

\footnotetext{
${ }^{38}$ Idem, ibidem, p. 145.

${ }^{39}$ PERRONE-MOISÉS, Leyla. O novo romance francês. São Paulo: São Paulo Editora S. A. 1966, p. 15.

${ }^{40}$ NITRINI, Sandra Margarida. Poéticas em confronto: Nove, novena e o novo romance. São Paulo: Hucitec; Brasília: INL, Fundação Nacional Pró-Memória, 19877, p. 45.
} 
Dissemos que o nivelamento do material narrativo de Lugar público configuraria um "romance de superfície". A expressão que, como vimos, foi cunhada por Roland Barthes, foi empregada para caracterizar principalmente o trabalho de Robbe-Grillet, mas também o de outros novos romancistas.

A tentativa de Robbe-Grillet (e de alguns de seus contemporâneos: Cayrol e Pinget, por exemplo, mas de um modo bem diverso) visa fundar o romance em superfície: a interioridade é posta entre parênteses, os objetos, os espaços e a circulação do homem de uns a outros são promovidos à categoria de assuntos. O romance se torna experiência direta do que cerca o homem, sem que esse homem possa prevalecer-se de uma psicologia, de uma metafísica ou de uma psicanálise para abordar o meio objetivo que ele descobre. $[\ldots]^{41}$

Características como a interioridade entre parênteses e a promoção das coisas à categoria de assuntos serão manifestas em Lugar público, mas também em PanAmérica, evidentemente que para tratar de temas distintos.

Sandra Nitrini afirma que os novos romancistas propunham uma "renovação das formas romanescas". De acordo com a estudiosa, a "renovação afeta principalmente a história e a personagem, elementos básicos da linguagem do romance". ${ }^{42}$ Nesse parentesco formal com os romances de Agrippino, podemos apontar a ausência de enredo, as descrições exaustivas de coisas e lugares, o não delineamento das personagens e, no caso específico de Lugar público, a repetição de trechos na mesma obra. Segundo Sandra Nitrini, os novos romancistas

[...] não pretendem suprimir tais componentes porque se o fizessem estariam negando a própria atividade produtora do romance. Propõem um

\footnotetext{
${ }^{41}$ BARTHES, Roland. "Literatura objetiva”. In: Crítica e verdade. Tradução de Leyla Perrone-Moisés. São Paulo, Perspectiva, 2013a, p. 92.

42 NITRINI, Sandra Margarida. Poéticas em confronto: Nove, novena e o novo romance. São Paulo: Hucitec; Brasília: INL, Fundação Nacional Pró-Memória, 1987, p. 45.
} 
novo tratamento à história e à personagem, embasados numa nova concepção da literatura e da realidade.

Resumindo o ideário do Novo Romance, pode-se dizer que o essencial da sua linguagem literária reside no trabalho de pesquisa sobre a própria linguagem enquanto escritura e não como veiculadora de um conteúdo. $[\ldots]^{43}$

A pesquisa sobre a linguagem e a "escritura" abordará diretamente o tempo na narrativa. Associando o Novo Romance Francês aos experimentos do começo do século, Leyla Perrone-Moisés disse que, "grosso modo, os renovadores do romance francês propunham, além de uma absorção mais completa na França das propostas de Franz Kafka, Marcel Proust e James Joyce, uma 'nova concepção do tempo romanesco"”. 44

O entendimento desse tempo exigia, na base, uma filosofia. Por trás das pesquisas dos novos romancistas estava o Existencialismo. Em sua História da literatura ocidental, depois de comentar o romance existencialista de autores como Jean-Paul Sartre, Otto Maria Carpeaux disse que “a filosofia na base desse 'nouveau roman' é uma ala extrema do existencialismo, e a ficção construída em cima dessa filosofia é evasionista e deliberadamente desumana". Segundo o crítico, os renovadores do romance na França tinham “convicção da impenetrabilidade das coisas e do mundo". ${ }^{45}$ A observação vai de encontro ao pensamento de Robbe-Grillet: "o mundo não é significante nem absurdo. Existe, muito simplesmente". ${ }^{6}$

Sandra Nitrini comentou a subjetividade dos novos romancistas ao abordarem uma realidade e um mundo inapreensíveis:

Os novos romancistas pretendem dar conta da realidade em termos de subjetividade, procurando, como os fenomenólogos, ultrapassar a dicotomia sujeito-objeto: o mundo real é o que vemos e é descrito do ponto

\footnotetext{
${ }^{43}$ Idem, ibidem.

${ }^{44}$ PERRONE-MOISÉS, Leyla. O novo romance francês. São Paulo: São Paulo Editora S. A. 1966, p. 19.

${ }^{45}$ CARPEAUX, Otto Maria. História da literatura ocidental. Volume IV. Brasília, Edições do Senado Federal, 2010 , p. 2827.

${ }^{46}$ ROBBE-GRILLET, Alain. "Uma via para o futuro romance”. In: Por um novo romance. Tradução de Cristóvão Santos. Lisboa, Publicações Europa América, 1965, p. 21 (grifo do autor).
} 
de vista subjetivo-objetivo de uma consciência humana. A consciência da personagem domina o romance e o mundo só existe na medida em que é refletido por ela. ${ }^{47}$

Nesses romances, qualquer comentário sobre o mundo será externo a ele e não poderá penetrá-lo. O sentido do mundo se perdeu ou, por outra, nunca houve sentido no mundo. Essa impenetrabilidade ou a falta de sentido exigirá do romancista novas técnicas e uma nova disposição do material narrativo. Por isso, os novos romancistas consideram-se continuadores da tradição do romance. Como observa Robbe-Grillet eles veem-se como parte da evolução histórica do gênero. “[...] É com os nomes dos nossos predecessores que somos mais facilmente postos de acordo; e a nossa ambição é apenas continuá-los. Não fazer melhor, o que não tem qualquer sentido, mas colocarmo-nos agora, nos nossos dias, na sua esteira". ${ }^{48}$ Daí as experiências formais que realizavam.

Em 1965, quando Lugar público foi lançado, José Geraldo Nogueira Moutinho apontou a inclinação existencialista da obra: "Este romance é moderno por amoldar-se à temática existencial mais legítima e mais próxima". ${ }^{49}$ De fato, na miríade de histórias da narrativa, o questionamento sobre o sentido da vida sobressai.

Os episódios envolvendo o narrador e seus amigos frequentemente expõem a falta de perspectiva. Mesmo que especule sobre o sentido da vida, sobre a razão ou a morte, o narrador sempre permanece apático, não demonstrando capacidade para a transformação.

Otto Maria Carpeaux observou que "talvez o impulso existencialista ainda não tenha esgotado suas possibilidades" e que "algo desse impulso sobreviveu no 'roman nouveau'; e os 'beatniks' de Nova York e San Francisco julgavam-se sucessores legítimos de [Boris] Vian e [Jean] Genet". ${ }^{50}$ Talvez devido às relações entre a beat generation e a contracultura,

${ }^{47}$ NITRINI, Sandra Margarida. Poéticas em confronto: Nove, novena e o novo romance. São Paulo: Hucitec; Brasília: INL, Fundação Nacional Pró-Memória, 1987, p.45.

${ }^{48}$ ROBBE-GRILLET, Alain. "Novo romance, homem novo". In: Por um novo romance. Tradução de Cristóvão Santos. Lisboa, Publicações Europa América, 1965, p 146.

${ }^{49}$ MOUTINHO, José Geraldo Nogueira. "Lugar público". In: A fonte e a forma. Rio de Janeiro, Imago, 1977, p. 36 .

${ }^{50}$ CARPEAUX, Otto Maria. História da literatura ocidental. Volume IV. Brasília, Edições do Senado Federal, 2010, p. 2822. 
comumente Agrippino é associado à literatura beat. Ainda que a aproximação seja possível, o próprio autor negava ter sofrido influências dos autores norte-americanos que integraram esse movimento. ${ }^{51}$

Sandra Nitrini apontou alguns dos procedimentos em comum trabalhados pelos autores do Novo Romance Francês: "novas estruturas narrativas e o tempo"; "uma nova dimensão: o tempo da escritura"; "a nova personagem"; "a descrição" e "o foco narrativo". Em relação à composição dramática, a pesquisadora destaca o anticlímax.

O Novo Romance não conhece a composição dramática, seu fio narrativo não é marcado por acontecimentos que se situam na zona de alto teor dramático, ao contrário, eles correspondem ao tempo morto ou branco dentro da linha evolutiva da ação. Quando ocorre um acontecimento dramático é por acaso: não chega a representar o coroamento do romance. A progressão narrativa para um fim é substituída por fenômenos de antecipação, similitude, repetição, variação etc. [...] ${ }^{52}$

O trecho é muito adequado aos romances de Agrippino. Nenhum de seus dois livros terá, a rigor, uma composição dramática. No caso específico de Lugar público, o livro é estruturado pela diversidade de relatos perpetrados por um narrador que se alterna entre protagonista e observador. Nenhuma das histórias apresentadas, nem mesmo aquela que referimos como a principal, a do jovem inadequado, apresenta uma progressão ou parte de uma situação inicial para atingir outra condição no desfecho da narrativa. A constante alternância de histórias e também a alternância da instância do narrador contribuem para

${ }^{51}$ Em 2004, em uma entrevista, Agrippino declarou: "Li a poesia de Allen Ginsberg. Ele fala de temas modernos, da cidade grande, dos problemas da vida moderna, do existencialismo. Mas a forma do Ginsberg é a de elegias, que é um pouco complicada. Não estou ligado a eles. Estou lendo mais JeanPaul Sartre, Henry Miller." (MACHADO, 2004). (Na fase final de sua vida, era comum que o autor se referisse ao passado no tempo presente.) Edwaldo Cafezeiro, que conviveu com Agrippino nos anos em que o autor estava escrevendo Lugar público, disse que a leitura de Henry Miller por Agrippino foi decisiva durante a feitura do livro (entrevista ao autor).

52 NITRINI, Sandra Margarida. Poéticas em confronto: Nove, novena e o novo romance. São Paulo: Hucitec; Brasília: INL, Fundação Nacional Pró-Memória, 1987, p. 47 (grifos da autora). 
reforçar o nivelamento do material narrado. Todos os relatos apresentados estão em pé de igualdade.

Diante da heterogeneidade das cenas, é de se supor que o tempo seja diferente em cada uma delas, mas não há nada, fora a alternância do assunto e do narrador, que garanta o passar do tempo. Em Lugar público, o único tempo que existe, podemos supor, é o tempo da própria escrita, o tempo dos acontecimentos revividos no momento da escrita.

Em comentário sobre a obra de Alain Robbe-Grillet, Roland Bartthes destacou a utilização, no Novo Romance Francês, do ponto de vista que, para o crítico, é fixado sobre uma única perspectiva, ao contrário do romance polifônico, em que diferentes vozes expõem diferentes pontos de vista.

[...] Em La Jalousie, em La Modification, em todas as outras obras do Novo Romance, acredito, a visão, uma vez inaugurada sobre um postulado preciso, é como que traçada em uma única linha, sem nenhuma intervenção daquelas consciências parasitas que permitiam à subjetividade do romancista intervir em sua obra declarativamente [...]. Por outras palavras, o mundo é falado de um só ponto de vista, o que modifica consideravelmente os respectivos "papeis" da personagem e do romancista. $[\ldots]^{53}$

Em Lugar público, o ponto de vista é único e não sofre interferência de "consciências parasitas", ou seja, de diferentes personagens ou mesmo de digressões que afastem o narrador (ou os narradores) do que está sendo narrado. E isso, como observou Barthes, modifica os papeis das personagens e do romancista. É interessante notarmos que, mesmo quando recorre aos dois diferentes narradores ou até mesmo quando expõe um diálogo com marcações como numa rubrica de teatro, o ponto de vista não se altera. Nem mesmo a multiplicidade de relatos interfere no ponto de vista do narrador, ao contrário, reforça-o. Além disso, não há no romance, comentários sobre o que se expõe, não cabe ao narrador analisar a matéria narrada.

\footnotetext{
${ }^{53}$ BARTHES, Roland. “A literatura hoje”. In: Crítica e verdade. Tradução de Leyla Perrone-Moisés. São Paulo, Perspectiva, 2013a, p. 77 (grifos do autor).
} 
O mosaico narrativo, mesmo quando evidencia cenas estranhas umas às outras, não dá uma dimensão de diversidade, Agrippino não exibe técnicas diversas para compor suas cenas, ele apenas as exibe ora de dentro, com o narrador-protagonista, ora de fora, com o narrador-observador. E isso cria um incômodo na leitura. A forma do romance, sua diversidade, expõe um único ponto de vista. Atento a isso, Nogueira Moutinho observou que, no bojo do narrador de Lugar público "gravita uma constelação de personagens, apenas debuxados, que parecem projeções do próprio eu do escritor [...]". ${ }^{54}$

Mesmo quando se trata das histórias protagonizadas pelo próprio narrador, e mesmo quando esse narrador se vê de fora para narrar a si mesmo em terceira pessoa, o que há, a rigor, é o ponto de vista único daquele indivíduo liquidado de que falava Adorno. O postulado, aqui, é o da impenetrabilidade, da inação e da apatia. Seja quando recorre à memória, à descrição ou à fantasia, na primeira ou na terceira pessoa, seja quando narra as próprias ações ou as ações de terceiros, o narrador jamais intervém declarativamente e raramente permite que outra personagem o faça. Quando o fazem soam como arremedos e são apáticas. A multiplicidade de relatos ajuda a compor as personagens e a reforçar o ponto de vista do narrador.

Por isso, paradoxalmente, poderíamos dizer que todo o livro é um romance de digressão, mas uma digressão diversa daquelas feitas pelo narrador de uma obra tradicional que siga a linha de um Laurence Sterne ou, exemplo mais próximo, de um Machado de Assis. Reconhecendo em Sterne o grande inventor do "romance inteiramente feito de digressões", Italo Calvino diz que

[...] a divagação ou digressão é uma estratégia para protelar a conclusão, uma multiplicação do tempo no interior da obra, uma fuga permanente; fuga de quê? Da morte, naturalmente, diz em sua introdução ao Tristram Shandy o escritor italiano Carlo Levi, que poucos imaginariam admirador de Sterne, ao passo que seu segredo consistia exatamente em adotar um espírito divagador

\footnotetext{
${ }^{54}$ MOUTINHO, José Geraldo Nogueira. "Lugar público”. In: A fonte e a forma. Rio de Janeiro, Imago, 1977, p.34.
} 
e o sentido de um tempo ilimitado até mesmo na observação dos problemas sociais. $[\ldots]^{55}$

Em Lugar público, a digressão se realiza na forma. Os relatos do narrador podem funcionar, de modo aleatório, como parênteses de uma e de outra coisa. Por exemplo, as histórias dos amigos configurariam parênteses do diário do narrador. As entradas deste, por sua vez, seriam os parênteses das cenas que o narrador observa. Já estas funcionariam como parênteses das cenas memorialísticas, as quais, por sua vez, desempenhariam o papel de parênteses das descrições fantásticas e assim por diante, num ciclo quase inesgotável até chegar à repetição. Mais para a frente, veremos como as cenas que têm por objeto a própria escrita exercem a função de fuga permanente da morte no romance, como sugere Carlo Levi.

As irrupções e interrupções dos relatos e o surgimento dos diversos blocos independentes na narrativa configuram a utilização do recurso do "mise em abyme", assim definido por Claudia Amigo Pino:

A partir da obra de Gide, o crítico Lucien Dallenbach define que a mise em abyme corresponde a toda inserção de uma narrativa dentro de outra que apresente alguma relação de similitude com aquela que a contém. $\mathrm{O}$ objetivo desse recurso seria pôr em evidência a construção da obra. Ao ler um relato construído dentro de outro, o leitor seria levado a pensar que o primeiro relato também é uma construção, não um universo paralelo. Esse princípio básico, segundo Dallenbach, tomaria várias formas diferentes, ou várias formas de reflexão diferentes. A primeira, a reflexão simples, inspirada em uma técnica de confecção de brasões, poderia ser definida como uma história dentro de outra história. A segunda, a reflexão ao infinito, toma como base o efeito produzido quando dois espelhos são colocados um na frente do outro e que se manifestaria na literatura sob a forma de um relato dentro de um relato similar, que por sua vez contém outro relato similar etc. Finalmente, a terceira reflexão [...] é a reflexão paradoxal, na qual as diferentes narrativas contidas uma dentro da outra (de forma simples ou

${ }^{55}$ CALVINO, Italo. Seis propostas para o próximo milênio. $2^{\mathrm{a}}$ edição. Tradução de Ivo Barroso. São Paulo: Companhia das Letras, 1998, p. 59. 
infinita) confundem-se, sem que o leitor possa, realmente, diferenciar o exterior e o interior de cada relato. [...] ${ }^{56}$

A terceira, a "reflexão paradoxal", é a que nos interessa. O efeito de estranhamento causado por Lugar público vem justamente da impossibilidade de o leitor poder diferenciar o "exterior e o interior de cada relato". Dissemos como essas histórias são independentes. Elas não contêm histórias dentro da história, mas o agrupamento para formar o livro as torna interdependentes, reforça a coerência da obra e contribui para o efeito final de que, de fato, nada acontece.

Essa espécie de tédio ou nulidade da narrativa é permitida pelo recurso da descrição. Cara aos novos romancistas, essa é a técnica narrativa mais recorrente no livro. Ela será um elemento fundamental na narrativa. É e descrição que vai estabelecer o ponto de vista único dos narradores. Se não cabe ao narrador interpretar o mundo, o que lhe resta é tentar apreendê-lo pela observação. Então o narrador observa e descreve, raramente, como vimos, utilizando a narrativa com a finalidade de comentário ou de análise. Ele mostra, dá a ver. Por isso o olhar, o que se mostra, é tão relevante. O espaço, o lugar no livro, vai se constituir pelas descrições do narrador.

Um morro de pedra, a forma é arredondada terminando numa ponta. Sobre o cume do morro repousa uma edificação retangular; um pequeno edifício. A silhueta do morro contorna o azul; o verde tinge algumas partes, umas feitas de florestas, outras, de uma vegetação rasteira. O operário carrega um pneu; ao seu lado, outro operário carrega uma caixa nos ombros. Umas construções de madeira, espécie de depósito ou galpão, cercam uma grande área de terra batida. Uma cor amarelada, com pequenos tufos de vegetação. Um tambor jaz no centro desta imensa área de terra; a ferrugem cobre toda a superfície. A haste vertical dos postes elétricos. Montículos de terra e detritos estão colocados ao lado de uma caixa d'água que é sustentada por uma armação de madeira. ${ }^{57}$

\footnotetext{
${ }^{56}$ PINO, Claudia Amigo. A ficção da escrita. Cotia, SP: Ateliê Editorial, 2004, p. 160-161.

${ }^{57}$ PAULA, José Agrippino de. Lugar público. Civilização Brasileira, Rio de Janeiro, 1965, p. 3.
} 
Um aeroporto: O passageiro desce, toma um café e parte para sempre. Não existe a possibilidade de um passageiro perder o avião. É um trânsito inverso. Enquanto que o passageiro deveria estar em trânsito no avião sobre a terra, o passageiro está em trânsito no aeroporto. O avião aterrissa a escada encosta no bojo do avião, o passageiro desce, toma um café e logo em seguida o alto-falante anuncia a partida. $O$ passageiro engole o café rapidamente, apressa o passo, transpõe o vestíbulo, sobe a escada metálica e entra no bojo da morte..$^{58}$

Descrição do quarto em que vivo. Um retângulo de três por nove metros. Janela de correr frente ao mar e a cidade ao longe. Vejo a cidade cintilante. Num plano mais avançado, um estaleiro gigantesco envia mensagens de bater ferros e brilhos fugidios das soldas eletrônicas. À direita, um morro arredondado coberto de casinholas escuras. No primeiro plano, uma enseada suja de óleo onde sobrevoam urubus e brancas garças. ${ }^{59}$

Dissemos, no começo do capítulo, que a delimitação geográfica não terá tanta importância na narrativa de Lugar público quanto a natureza da interação dos seres com o lugar ou com os lugares a que estão sujeitos.

Sabemos que Lugar público foi escrito, ao menos em parte, durante os anos e alguns eventos que antecederam o golpe militar de 1964. Na miríade de relatos do livro, episódios históricos, como a Marcha da Família com Deus pela Liberdade, são citados. Há ao menos uma cena em que o narrador se vê em meio a manifestações em defesa do governo que seria deposto. A irrupção da História na narrativa reforça a instabilidade e a falta de perspectiva do narrador e das personagens, mas a disposição dos relatos torna as referências rarefeitas.

A exemplo das rupturas temporais da narrativa, dos saltos no tempo que se dão de um bloco para outro, mas também no interior dos relatos, a ação do romance salta de um lugar para o outro. Como raramente sabemos de que tempo o narrador está tratando, se do tempo presente, de um passado recente ou de uma memória longínqua, muitas vezes não

\footnotetext{
${ }^{58}$ Idem, ibidem, p. 25.

${ }^{59}$ Idem, ibidem, p. 195.
} 
conseguimos situá-lo no espaço com precisão, naquelas que são, afinal, as duas referências espaciais mais precisas da narrativa, as cidades de São Paulo e do Rio de Janeiro.

O espaço, no romance, portanto, não é determinante. Ele é apenas o lugar onde as personagens estão ou circulam, ou seja, não é o espaço que determina suas ações, ao contrário, são suas ações, notadamente o caminhar e o peregrinar pelas cidades, que as situam no espaço. Elas podem estar em meio a uma manifestação ou numa biblioteca, num alojamento estudantil ou em casa, pouco importa. Não há uma convenção, o espaço não é um lugar determinado e fixo. Em diversas cenas, não sabemos ao certo onde as personagens estão. Mesmo quando situadas, as personagens parecem sempre estar deslocadas.

As personagens do livro são flagradas como se captadas por uma câmera que fizesse um sobrevoo pela cidade e delas se aproximasse para mostrar ações comezinhas dos seres inseridos em uma realidade precária. Não é à toa que o cinema tenha destaque na narrativa como um dos ambientes em que os personagens se movem, mas ele também aparecerá na citação de nomes de filmes e de atores, como uma expressão presente na narrativa e na vida daquelas personagens.

Lugar público se passa, em grande parte, ao ar livre, a céu aberto. Mesmo quando o narrador ou as personagens que ele acompanha encontram-se ou passam para os interiores, eles são logo reconduzidos à rua, à via pública. A vivência na via pública ocorre de modo paradoxal porque é uma existência claustrofóbica, opressiva. Esse movimento choca-se com a interiorização da figura do narrador, espécie de contraponto do lugar público.

Os cenários são essencialmente urbanos, onde o homem não só está em contato com os elementos da cidade, mas às vezes se embate com eles. Em muitos momentos, as construções, os aparelhos e objetos da vida cotidiana são igualados à condição das personagens. Em seus comentários sobre o romance de Allain Robbe-Grillet, Roland Barthes observou que os objetos "são feitos para estar ali". ${ }^{60}$ Para o crítico, "toda a arte do autor consiste em dar ao objeto um 'estar ali' e em retirar-lhe um 'ser alguma coisa"". ${ }^{61} \mathrm{O}$ mesmo acontece em Lugar público. Como em Robbe-Grillet, na obra romanesca de Agrippino, nesse

\footnotetext{
${ }^{60}$ BARTHES, Roland. "Literatura objetiva”. In: Crítica e verdade. Tradução de Leyla Perrone-Moisés. São Paulo, Perspectiva, 2013a, p. 84.

${ }^{61}$ Idem, ibidem, p. 84.
} 
romance e também em PanAmérica, as descrições têm tanta importância quanto os demais elementos constitutivos.

[...] Sabe-se que o desígnio de Robbe-Grillet é dar afinal aos objetos um privilégio narrativo somente concedido até hoje às relações humanas. De onde uma arte da descrição profundamente renovada, já que nesse universo "objetivo" a matéria não é mais apresentada como uma função do coração humano (lembrança, utilidade) mas como um espaço implacável que o homem só pode frequentar pelo andar, nunca pelo uso ou pelo sujeição. ${ }^{62}$

Agrippino parece ter absorvido a "arte da descrição profundamente renovada" de que fala Roland Barthes. Em Lugar público, o narrador e as personagens erram, caminham, se deslocam. E é precisamente nesse movimento, também caracterizado na fragmentação que marca o romance, que as descrições ocupam um lugar central. Ainda que não penetrem no mundo, na realidade em que os elementos do livro estão inseridos, as descrições são o que configuram esse mundo inalcançável.

Sobre o uso da descrição no Novo Romance Francês, Sandra Nitrini observou que a técnica "constitui também um instrumento para contestar a história". ${ }^{63}$ A pesquisadora faz uma distinção entre o uso do recurso no romance tradicional e no Novo Romance. Para ela, a descrição é contestadora "no contexto da escritura".

[...] Contrapondo-se aos escritores tradicionais que, ao valorizarem extremamente a história, multiplicam as ações no interior das descrições, os novos romancistas "multiplicam a descrições no interior das ações". As interrupções frequentes e abruptas, provocadas pelas descrições, impedem e atravancam o desenvolvimento do fio temporal da história. ${ }^{64}$

\footnotetext{
${ }^{62}$ Idem, "Literatura literal”. In: Crítica e verdade. Tradução de Leyla Perrone-Moisés. São Paulo, Perspectiva, 2013a, p. 94.

${ }^{63}$ NITRINI, Sandra Margarida. Poéticas em confronto: Nove, novena e o novo romance. São Paulo: Hucitec; Brasília: INL, Fundação Nacional Pró-Memória, 1987, p. 54.

${ }^{64}$ Idem, ibidem, p. 54-55.
} 
Essa função de interrupção da história que, a rigor, será o método compositivo de Lugar público vai ser melhor explorada, paradoxalmente, na repetição de relatos, outro recurso comum no Novo Romance. Isso porque, além de descrever, Lugar público apresenta relatos repetidos, como já vimos no episódio do pai acordando pela manhã e limpando a pele seca que se despregou de seu corpo durante a noite. As repetições acontecem principalmente nas histórias protagonizadas ou relembradas pelo narrador. Vejamos alguns exemplos de relatos repetidos.

Meu pai ensinava solfejo para mim. Movimentava as mãos para o lado e dizia alto: um, dois, três, quatro; um, dois, três, quatro. ${ }^{65}$

O corpo de meu pai jazia no andar inferior. Minha tia soltava lamúrias. Acordei durante a noite, desci e olhei o corpo do meu pai iluminado pela luz tênue das velas. Subi novamente e dormi. Acordei ao amanhecer. ${ }^{66}$

Ele foi eliminado da mesa de jogo, não que ele fosse um dos jogadores; ele era uma das peças do jogo. ${ }^{67}$

Ainda segundo Nitrini,

A técnica de cenas repetidas com ou sem pequenas variações, indicada também pelo termo de reduplicação, pode ser comparada ao processo fenomenológico de variação livre "que consiste em modificar livremente pela imaginação as relações nas quais o objeto é representado", permitindo, assim, reterem-se as invariantes e atingir-se a essência.

As constantes retomadas com pequenas modificações das mesmas cenas ou situações de uma narrativa, que se caracteriza essencialmente pela sua adramaticidade, parecem corresponder a uma espécie de variação livre de pequenas parcelas do real vivido, dentro da nova ficção. Esta técnica empregada pelos novos romancistas também em outras instâncias narrativas,

\footnotetext{
${ }^{65}$ PAULA, José Agrippino de. Lugar público. Civilização Brasileira, Rio de Janeiro, 1965, p. 8, 61, 93, 143.

${ }^{66}$ Idem, ibidem, p. 26, 43, 64.

${ }^{67}$ Idem, ibidem, p. 56, 61, 152.
} 
no nível da personagem, do espaço e do objeto é bem representativa do pressuposto teórico que está na base poética do Novo Romance: a realidade é complexa, o mundo não é regido por uma unidade significativa, pelo contrário, todas as coisas se inserem numa ampla rede de relações e de significações. ${ }^{68}$

Os trechos repetidos de Lugar público normalmente não apresentam variações, ainda que isso ocorra. Dissemos que a intercalação dos relatos reforça a sensação de nulidade, o que ajuda a adensar a "adramaticidade" da obra. Quando deparamos com a repetição de um parágrafo, o efeito se acentua e pode adquirir novos significados.

Ainda que a repetição seja um procedimento que auxilie o leitor, uma vez que, em meio a tantos fios apontando para direções diversas, as histórias repetidas se tornem familiares, o recurso parece servir para reforçar o efeito de dissolução. ${ }^{69}$ É como se no narrador encarnasse um indivíduo que parece estar se extinguindo ou desvanecendo e retomasse a consciência para logo em seguida ser mais uma vez interrompido por um novo acontecimento que reforça a impenetrabilidade do mundo e a impossibilidade de prosseguir. Como se uma história soterrasse a outra. Nesse caso, o recurso, obsessivo para o narrador, pode servir como uma tentativa de organização ou de reorganização do mundo. Além disso, as repetições servem para reforçar a sensação de apatia. Os relatos repetidos funcionam como uma espécie de "eterno retorno" da existência.

Há um fenômeno recorrente nos relatos protagonizados pelo narrador que parece confirmar a impenetrabilidade do mundo e sua consequente impossibilidade para a ação. Trata-se da chuva. Ela funciona como uma metáfora da condição das personagens do romance, já que é, em si, um fenômeno de limitação ou, no mínimo de alteração da normatividade de atuação dos seres, não só humanos. Não por acaso, a chuva é associada à melancolia, à tristeza ou, no mínimo, a uma condição interiorizada que nos desloca da

\footnotetext{
${ }^{68}$ Idem, ibidem, p. $48-49$.

${ }^{69}$ Nas centenas de cadernos do período em que Agrippino viveu em Embu das Artes, ele tinha anotações para uma peça que se chamaria $A$ repetição.
} 
realidade objetiva para nos lançar a um estado de interiorização. O cinema aproveitou muito bem o efeito causado por esse fenômeno. No livro de Agrippino isso também ocorre. Não poucas passagens situam narrador e personagens abrigados da chuva, olhando e esperando.

Chove. Estou na seção de revistas e jornais da biblioteca. Sala semicircular e uma mesa contínua semicircular. Um velho, sujo e paupérrimo, sentado à minha frente, olha horizontalmente para a janela. Nas minhas costas um homem dorme de cabeça pendida frente ao jornal. Um outro velho lê desinteressado um jornal. Chove. Uma chuva insistente. Céu cinzento e escuro. Saí à porta para tomar um café e desisti voltando a escrever. $[\ldots]^{70}$

Nada por escrever. Sonolência completa. Domingo de chuva. Sorrisos, três mulheres sorriem. Gritam, falam alto. Ferem os meus ouvidos. Extremamente sensível. Volta a estados adolescentes de angústia sem sentido, um absurdo claro e lúcido. ${ }^{71}$

[...] Fechou a porta e saiu. A chuva estava fraca. Atravessou a rua, dobrou a esquina e parou frente ao ponto de ônibus. Subiu no ônibus. Repetiu-se o cenário da tarde, acrescentando-se ainda o escuro da noite e o brilho das luzes. Desceu do ônibus. A cidade iluminada, as vitrinas iluminadas, as luzes, os carros, os faróis brilhantes... [... $]^{72}$

Pelos exemplos, podemos observar que a chuva também está associada à escrita. $\mathrm{O}$ narrador se recolhe para produzir os relatos e a chuva parece interferir em sua disposição para narrar até o ponto em que a própria escrita assume o protagonismo. Há um bloco ou parágrafo, entretanto, em que a chuva leva o narrador a refletir de modo mais profundo sobre sua condição e sobre a condição humana.

\footnotetext{
${ }^{70}$ PAULA, José Agrippino de. Lugar público. Civilização Brasileira, Rio de Janeiro, 1965, p. 47.

${ }^{71}$ Idem, ibidem, p. 152.

${ }^{72}$ Idem, ibidem, p. 217.
} 
Ele estava numa fila de homens e mulheres que olhavam indiferentes a chuva. A sua consciência estava absorvida por aquele jogo variado e contínuo das gotas batendo no asfalto. Ele pensou que aquela fila estava à espera da morte, e não só aquela fila de homens e mulheres, mas todas as filas do mundo e toda a humanidade estava à espera da morte. O que tornava esta espera única e particular era a falta de emoção que acompanhava este acontecimento, uma placidez e resignação. A norma diz que cada um possui o seu momento e que a impaciência é desnecessária. Todos aguardavam um mesmo resultado, mas apesar deste fato ser comum a todos, não contribuía para a união de todos num choro geral. Todos percebiam a gravidade deste termo: aguardar a morte; mas nenhum deles esboçava um gesto de revolta ou violência, permaneciam tranquilos encarcerados em seus ossos e em sua carne. A união se daria fora deste campo, fora desta espera intransferível, a união se daria depois de ter cessado a espera, uma união onde as vozes se dispersavam num choro silencioso. ${ }^{73}$

A fila representa uma espera maior, existencial. O que nos resta? Esperar somente? A resignação dos seres que olham indiferentes a chuva torna-se um pequeno desabafo do narrador contra a passividade, mas até mesmo o desabafo é um registro dessa passividade, uma revolta inútil que se encerra em si mesma.

Em contraposição, outro bloco situa o narrador como o líder de uma multidão, não por acaso, de loucos. Talvez a única maneira de se revoltar, de deixar a condição de passividade seja assumir a loucura latente e, a partir dela, tornar-se agente da transformação.

Ele está enfermo e tenta curar a si mesmo. Ele conduz uma multidão de loucos; ele é o líder, o curandeiro, a única esperança. Ele volta o rosto para a multidão e pronuncia um discurso. O discurso diz que os loucos devem expor suas feridas ao sol e às moscas. A multidão murmura perplexa, mas ele grita e reafirma a sua doutrina. As suas próprias feridas, ele cobre de fragmentos de animais mortos, e ele usa um capacete dourado. ${ }^{74}$

\footnotetext{
${ }^{73}$ Idem, ibidem, p. 15-16 e 147.

${ }^{74}$ PAULA, José Agrippino de. Lugar público. Civilização Brasileira, Rio de Janeiro, 1965, p. 105. 
A cena, uma das mais delirantes do livro, será um germe do que será explorado em PanAmérica. Ainda que Lugar público se pareça uma narrativa calcada na realidade, em diversos momentos a representação do real será abalada.

\section{Realidade deformada}

Dissemos que, em Lugar público, o evento moderno também é personagem da narrativa. Algumas das descrições do livro dão autonomia aos acontecimentos, como se a técnica, as conquistas tecnológicas ganhassem vida. $\mathrm{Na}$ economia do romance, essa autonomia tem a mesma importância existencial que as personagens. As coisas, os objetos e acontecimentos, concorrem com os seres. Exemplos disso são as descrições de uma corrida de automóveis e a da decolagem de um avião, por exemplo, que configuram alguns dos mais belos momentos do livro. Essas descrições dão a dimensão da complexidade dessa vivência urbana.

A noção da autonomia da técnica moderna será exagerada com as descrições de objetos modernos como se fossem coisas fantásticas.

[...] O estacionamento dos ônibus às escuras, um parado aqui, outro lá. Encostei numa grade e observava o radiador do ônibus. Semelhante a uma boca: dentes cerrados como se sentisse uma dor terrível. A boca do ônibus, e os faróis: os olhos. Era uma dor constante e ao sofrimento misturava-se um rir do sofrimento. ${ }^{75}$

Nesse exemplo, além da relação metafórica com o ponto de vista do narrador, vemos a autonomia do elemento fantástico. Aparentemente um romance realista, Lugar público é abalado em diversas passagens por relatos fantásticos que se infiltram na narrativa.

\footnotetext{
${ }^{75}$ Idem, ibidem, p. 29.
} 
Modesto Carone, ao comentar a obra de Franz Kafka, disse: "o que chama a atenção no texto é a crescente deformação da realidade". ${ }^{76} \mathrm{O}$ mesmo parece acontecer em Lugar público. As descrições deformadas da narrativa lembram relatos surrealistas e algumas cenas se assemelham a delírios e relatos de sonhos. Vejamos alguns casos:

[...] Uma das tias gemia e levanta-se de instante a instante indo debruçar a cabeça nas mãos entrelaçadas do cadáver. Um terço entre os dedos e algumas flores cercando o ombro. O cadáver do meu pai chorava, esfregando as mãos nos olhos, e dizia que não queria morrer. Eu não me recordo se eu e meu pai ocupávamos o mesmo corpo e o mesmo caixão. As minhas tias me consolavam acariciando os meus cabelos. Diziam elas: "Não chore." O cadáver de meu pai esfregava as mãos nos olhos, chorando como uma criança $[\ldots]^{77}$

Eu caminhava sobre o meu único pé. Consegui salvar da destruição minha cabeça e o meu pé. Eu estava careca, os meus cabelos caíram, e a minha cabeça se unia diretamente ao pé. Eu caminhava saltitando para frente usando a ponta do pé e os dedos. Quando me sentia cansado de caminhar desta forma, rolava a minha cabeça e o meu pé de lado. Eu saltitava no meio dos escombros de um prédio e vi um tonel de óleo. Eu ocupava uma plataforma superior a este tonel. No interior do tonel consegui reconhecer Robespierre e Cícero. Eu acenei para eles com o dedão do pé e perguntei: "Tudo bem?" [...] ${ }^{78}$

Em muitos dos blocos, o narrador e seus amigos protagonizam peripécias em que a verossimilhança é posta à prova, como por exemplo, na inauguração de uma estátua em que o monumento é o corpo empalhado do próprio homenageado.

\footnotetext{
${ }^{76}$ CARONE, Modesto. Lição de Kafka. São Paulo: Companhia das Letras, 2009, p. 49.

${ }^{77}$ PAULA, José Agrippino de. Lugar público. Civilização Brasileira, Rio de Janeiro, 1965, p. 107.

${ }^{78}$ Idem, ibidem, p. 139.
} 
Era a inauguração de uma estátua; a estátua era a homenagem prestada ao suicida Pio XII. Um padre subiu numa parte elevada da parede, e pronunciou um discurso. O lugar lembrava uma igreja gótica. O discurso do padre foi interrompido pela chegada da estátua. Um dos homens fortes carregava a estátua, que era feita de Pio XII empalhado. O corpo estava inerte e um pouco murcho; batia, quando carregado pelos homens fortes, na multidão aglomerada em torno do padre. ${ }^{79}$

Também nas descrições dessas cenas deformadas, haverá relatos apenas observados, que não terão a participação do narrador e de seus amigos. Uma delas é repetida ora ipsis litteris, ora com informação complementar, o que cria a sensação de que terá um desfecho ao final do romance, mas também ela não se completa.

O homem, provido de umas pequenas asinhas no ombro e um leme preso ao ânus, lança-se do terraço de um edifício de trinta andares. Sobrevoa a multidão que o aplaude, faz uma curva em torno de um obelisco, perde a altura e cai, sendo espetado pro um mastro de bandeira. ${ }^{80}$

O homem, levando uma bandeira espetada no ânus, é carregado aos céus por uma águia. ${ }^{81}$

A irrupção do fantástico, nesse livro, é uma antecipação do conteúdo que será explorado à exaustão em PanAmérica, romance em que o suprarreal será levado ao paroxismo.

Outra característica que abala a verossimilhança e deforma a realidade do livro, a rigor um dos elementos que primeiro chamam a atenção do leitor de Lugar público, é a nomeação das personagens que convivem com o narrador. Em contraste com o protagonista "Eu" inominado, os seres que vagueiam no espaço do romance têm nomes de personalidades históricas ou mitológicas como, por exemplo, Cícero, César, Bismarck, Pio XII, Moisés,

\footnotetext{
${ }^{79}$ Idem, ibidem, p. 112.

${ }^{80}$ Idem, ibidem, p. 26, 148.

${ }^{81}$ Idem, ibidem, p. 37, 137.
} 
Robespierre, Péricles, Galileu, Constantino e Alexandre. Qual seria o significado desses nomes? Que função eles têm, se é que têm, na narrativa?

Para respondermos a essas perguntas, precisamos pensar na função do nome na literatura. Ana Maria Machado, que analisou a função do nome na obra de Guimarães Rosa, disse sobre o uso do nome próprio:

[...] Não nos deixemos enganar pela expressão nome próprio. Por que próprio? Propriedade de seu portador? Por um lado, se o Nome é uma marca de individualização, de identificação do indivíduo que é nomeado, ele marca também sua pertinência a uma classe predeterminada (família, classe social, clã, meio cultural, nacionalidade etc.), sua inclusão num grupo. O nome próprio é a marca linguística pela qual o grupo toma posse do indivíduo, e esse fenômeno é geralmente assinalado por ritos, cerimônias de aquisição ou mudança de Nome. A denominação é também a dominação do indivíduo nomeado pelo grupo. ${ }^{82}$

Se o nome próprio é a marca linguística pela qual o grupo toma posse do indivíduo, ao nomear os membros do grupo com nomes que representam individualidades com referências históricas, podemos especular que o autor estava pensando em duas estratégias. A primeira seria a de esvaziar o sentido histórico, rebaixando as personagens, já que os nomes grandiloquentes circulam agora por centros urbanos da periferia do mundo no século XX. Fora os nomes, as personagens não têm relação alguma com as figuras cujos feitos garantiram seu lugar na História. Durante a leitura, no entanto, é difícil abandonarmos essas referências, ainda que os seres vivam acontecimentos comezinhos, aventuras no mais das vezes insignificantes.

A segunda estratégia é que, nomeando-os desse modo, o autor estaria colocando um elemento não verossímil na narrativa para indicar que as personagens podem não ser reais como indivíduos. A recorrência aos nomes nos faz pensar na mitologia, uma vez que o deslocamento proposto pelo autor se adéqua bem à transitoriedade do mito que, por si, está

\footnotetext{
${ }^{82}$ MACHADO, Ana Maria. Recado do nome: leitura de Guimarães rosa à luz do Nome de seus personagens. São Paulo: Companhia das Letras, 2013, p. 28.
} 
fora da inscrição histórica. Muitas vezes, os nomes históricos suplantam os indivíduos que identificaram um dia e erguem-se à altura do mito, operação que o autor realizará de modo ainda mais radical em PanAmérica.

Em Lugar público, a referência produz um efeito incômodo, mais um entre tantos causados pela narrativa. Não deixa de ser irônico que Agrippino traga da História nomes consagrados para lançá-los em uma vivência prosaica e quase medíocre. Por outro lado, ainda que seja impossível pensar na escolha ao acaso, os nomes podem representar uma irrelevância.

César, por exemplo, não é o ditador romano. Napoleão não é o general e imperador francês. Os nomes grandiloquentes podem até contrastar com o narrador sem nome, mas as ações que essas personagens praticam, triviais como as ações do próprio narrador, longe de feitos grandiosos, dão a sensação de que o nome simplesmente não importa, já que nenhuma personagem tem personalidade completamente desenvolvida. Elas se igualam, não chegam a constituir uma psicologia. Não são, como em uma história narrada em uma situação espacial e temporal rigorosamente delimitada, caracterizáveis, como ocorria no romance do século XIX.

[...] Ter um nome era, sem dúvida, muito importante no tempo da burguesia balzaquiana. Era importante um caráter, tanto mais importante quanto mais fosse a arma de um corpo a corpo, a esperança de um êxito, o exercício de um poder. Era alguma coisa o ter uma fisionomia num universo em que a personalidade representava do mesmo passo o meio e o fim de toda a pesquisa. ${ }^{83}$

A citação de Robbe-Grillet indica que as representações, na literatura, tinham mudado. Para o autor francês, "o romance de personagens pertence inteiramente ao passado, caracteriza uma época: a que marcou o apogeu do indivíduo". ${ }^{84}$ Ora, Lugar público aparece no momento da ascensão das sociedades de massa, da desinvidualização e da anulação da

\footnotetext{
${ }^{83}$ ROBBE-GRILLET, Alain. "Acerca de algumas noções obsoletas". In: Por um novo romance. Tradução de Cristóvão Santos. Lisboa, Publicações Europa América, 1965, p.33.

${ }^{84}$ Idem, ibidem.
} 
individualidade. As personagens da narrativa não têm um delineamento e um psicologia precisas. Elas passam a maior parte do tempo vagueando ou travando conversas sobre temas rasteiros. Têm, de fato, aspirações rasteiras. Seus objetivos não têm uma função narrativa. Nada do que fazem impele a narrativa adiante uma vez que não têm, no plano narrativo, objetivos a serem alcançados. Suas ações e ambições encerram-se nos próprios relatos.

Na narrativa clássica, diz Robbe-Grillet, “convém que a personagem seja única e ao mesmo tempo se eleve a grande altura". ${ }^{85}$ Ela "precisa de muita originalidade para ser insubstituível e de muita generalidade para se tornar universal". ${ }^{86}$ Já na narrativa moderna de Lugar público podemos dizer que as personagens são todas substituíveis. São uma, mas bem poderiam ser outra. Não é possível distinguir César de Cícero ou de Robespierre, por exemplo. Não há traços únicos, distintivos, para cada um deles, o que lhes garante a unidade são exatamente seus nomes, não as ações ou características. Os nomes funcionam como o que são: elementos de identificação e individualização, mas não chegam a formar uma personalidade. Sem eles, seria impossível reconhecer as personagens, cujas ações podem ser atribuídas com facilidade a qualquer outra.

Ao depararmos com uma dessas personagens em nova aparição, nossa tendência é de tentar reconhecê-las. O esforço, porém, é inútil, pois elas não chegam a se constituir como indivíduos na concepção exata do termo. Ou, por outra, sua individualidade e existência são aplainadas pela realidade em que estão inseridas. As personagens são seres igualados. Funcionam, como apontou Nogueira Moutinho, como "projeções do próprio eu do escritor", 87 como facetas do narrador cindido. As cenas que as envolvem, portanto, reforçam a condição precária do narrador, mesmo quando ele apenas as observa.

Lugar público recria alguns acontecimentos da vida de José Agrippino de Paula. O autor utilizou muito de sua história na composição do romance, principalmente no que diz respeito à memória do narrador. Por isso, alguns relatos autobiográficos nos permitem traçar um perfil mais delineado desse “Eu”. São histórias protagonizadas por um jovem que saiu de

\footnotetext{
${ }^{85}$ Idem, ibidem, p. 32.

${ }^{86}$ Idem, ibidem.

${ }^{87}$ MOUTINHO, José Geraldo Nogueira. “Lugar público”. In: A fonte e a forma. Rio de Janeiro, Imago, 1977, p. 34.
} 
São Paulo para estudar no Rio de Janeiro. Deixa para trás a mãe viúva e um irmão que depositam nele expectativas. Traz consigo lembranças do pai, morto quando ele tinha dezenove anos. Prestes a se formar em arquitetura, faz bicos em um programa de televisão e atua no teatro. Tem incertezas quanto ao futuro geradas pelo fato de saber que não pode, porque se sabe incapaz, inserir-se na sociedade do trabalho.

Além do narrador, duas personagens têm mais autonomia que as demais na narrativa. São as precisamente as figuras do pai e da mãe do protagonista. Enquanto esta vive os dilemas da viuvez e de ter um filho que, ela parece saber em seu íntimo, não é capaz de enfrentar a vida prática, o pai é um fantasma que vive nas cobranças que a mãe faz sobre o filho, mas principalmente nas memórias e na consciência às vezes alucinada deste. A personagem do pai irrompe, como todo o resto, em meio aos demais relatos. As cenas que o envolvem, normalmente, são as que mais se repetem ao longo do livro.

Ainda que, como o filho, o pai tenha um perfil mais delineado, essa representação não é completa e não podemos saber da sua história com exatidão. Portanto, tudo o que nos resta é acessá-la por meio dos fragmentos das lembranças do narrador.

[...] Entraram os dois no elevador. O pai silencioso, o filho silencioso. Abandonaram o elevador e entraram numa saleta volteada de cadeiras. O pai empurrou a porta de vidro onde estava escrito: "Consultório médico", e entrou. A mulher fez um gesto e entrou no consultório. $\mathrm{O}$ médico abriu a porta. Avental branco, óculos sobre o nariz, face rosada... o médico entregou uma folha de papel onde estava escrito e impresso o resultado dos exames de sangue. O pai olhou para o papel, olhou para o médico, e disse: "O trabalho do senhor. Quanto custa?" O médico respondeu uma quantia e o pai perguntou se ele não poderia fazer um abatimento. $\mathrm{O}$ médico disse que não era possível um abatimento; o preço era justo. Ele estava impaciente e não compreendia a razão da insistência do pai; o preço não era elevado e a redução proposta pelo pai era insignificante. Mas o médico insistia em ser intransigente; o preço do exame de sangue deveria ser mantido. O pedido do pai não visava uma diminuição do preço, já que a quantia proposta era insignificante. O médico continuava negando; e este negar servia objetivamente ao desejo do pai que acrescentava a cada negação do médico 
uma nova insistência. A voz do pai era na forma de lamento. O pai abandonou o consultório acompanhado pelo filho. O pai e o filho desceram a rua, dobraram a esquina e o pai disse: "Você não precisa ir para casa. Se quiser ficar na cidade...” O pai silenciou alguns instantes, olhou a mão, acariciou a mão, e disse ao filho: "A minha mão..." O filho respondeu: "Eu fico na cidade." O pai acariciou a mão, limpando os fragmentos de pele seca que se acumulavam sobre ela; e repetiu: "Você fica na cidade..." O pai enfiou as duas mãos no bolso do paletó e entrou no ônibus. O ônibus cerrou a porta automaticamente e partiu. Ele permaneceu alguns instantes perdido em divagações, virou o rosto, olhou para o monumento, e atravessou a rua. ${ }^{88}$

A personagem do pai é fundamental para entendermos a apatia do narradorprotagonista, cujas fraquezas e temores têm, provavelmente, origem familiar. O pai é a figura central do diário e das memórias do narrador. Ele funciona como uma espécie de consciência externa da precariedade do filho.

O seu pai dizia que a ele, o seu filho, faltava qualquer coisa de fundamental, como a falta dos braços; não por acidente, mas a falta foi gerada no ventre materno, e não por culpa do ventre materno, mas por culpa dele; que foi e pretende ser essencialmente corrupto e mau. "O seu defeito, dizia o seu pai, teve origem no ventre materno, mas isto não significa que você, meu filho, está isento de culpa por este defeito; mas justamente ao contrário, você é o único culpado; e o que é mais grave, este defeito pertence a você e é irrevogável. Toda a tentativa da sua parte de eliminá-lo está predestinada ao fracasso. Não perca tempo e esforço tentando vencer a si mesmo. Prossiga na sua insignificância, indigência, ociosidade e autoaniquilamento". ${ }^{89}$

Podemos observar no texto uma voz oracular, do passado, que deixou marcas na consciência do filho. Essa voz desde cedo identificou nele a indigência e a inabilidade para a realização. O vaticínio do pai é uma das falas mais longas de uma personagem da narrativa.

\footnotetext{
${ }^{88}$ PAULA, José Agrippino de. Lugar público. Civilização Brasileira, Rio de Janeiro, 1965, p. 2-3.

${ }^{89}$ Idem, ibidem, p. 105, 183.
} 
A cena, de forte dramaticidade, o que é raro no romance, reforça no narrador não uma culpa pelo defeito que o pai lhe acusa, mas uma espécie de complacência. Fadado ao fracasso, resta ao filho observar, descrever. Ele parece incutir em sua própria consciência a consciência do pai. Todo esforço que fará, não importa qual, não importa como, será destinado ao fracasso.

Esse pequeno relato e, a rigor, toda a relação pai e filho lembram o conto "O veredicto", escrito por Franz Kafka e tido como o "texto em que o autor descobre sua forma específica de narrar", segundo Modesto Carone. De acordo com o tradutor e estudioso da obra de Kafka, é esse o conto que "introduz a sequência das obras primas kafkianas".

[...] O consenso crítico é de que $O$ veredicto contém a estrutura básica que as demais narrativas desenvolvem e submetem a pequenas variações. Do ponto de vista temático, é a primeira novela (ou conto longo) do autor em que aparecem não só o motivo recorrente da condenação e da morte (por uma culpa desconhecida) como também a figura que encarna uma força vital - o Pai - que baixa a pena capital sobre um eu desgarrado ou alienado de si mesmo. ${ }^{90}$

A figura do "Pai" no conto kafkiano se assemelha ao pai do "Eu" protagonista de Lugar público. Ao contrário, porém, do pai da personagem Georg Bendemann em "O veredicto", o pai do narrador de Lugar público não irá lhe impor uma sentença expressa, mas seu vaticínio sobre as características do filho vai se imprimir sobre ele, seja pelo que tem de atávico, seja porque o pai o deixou marcado.

A memória da figura paterna que se materializa na narrativa acaba contaminando pensamento e ações do filho. As opiniões de pai sobre o filho, as características, sempre negativas, que o pai identifica no filho acabam se tornando parte dele. Comparemos alguns excertos:

[...] O seu pai valorizava os aniversários e reuniões familiares. Em um deles, ele deveria ter quinze anos, seu pai e sua mãe organizaram uma festinha. Ele

\footnotetext{
${ }^{90}$ CARONE, Modesto. Essencial Franz Kafka / seleção, introdução e tradução de Modesto Carone. São Paulo: Penguin Classics Companhia das Letras, 2011, p. 27.
} 
teve que esperar os tios, primos e tias cantarem para apagar as velinhas do bolo. Constrangimento da sua parte e insatisfação. O seu pai admitia que ele possuía um caráter negativo: o egoísmo; e que ele, o seu filho, eliminava qualquer respeito ao afeto dos outros. ${ }^{91}$

O corpo de meu pai jazia no andar inferior. Minha tia soltava lamúrias. Acordei durante a noite, desci e olhei o corpo de meu pai iluminado pela luz tênue de velas. Subi novamente e dormi. Acordei ao amanhecer. ${ }^{92}$

Em outros momentos, sem que o pai apareça nos relatos, diz o narrador sobre si mesmo:

Algumas características infantis: lento, tímido, negligente, pouco interessado no que aos outros interessa. [... ${ }^{93}$

Insignificância. Pequeno. Minúsculo. Absurdo. Inútil. Difícil determinar as relações. Estou ligado a alguma coisa? Estou ligado a alguma coisa? Esquecimento de origem. ${ }^{94}$

Confuso. Confuso, mas ocioso. Indolência cotidiana. Problema econômico, o mais grave? Esgotamento físico e psicológico. [... $]^{95}$

[...] Eu sou mesquinho, insignificante, ocioso. Mas admiro o esforço humano. Se eu tivesse capacidade de furar, furar o mesmo ponto sem me perder em coisas desprezíveis. Morder o próprio pescoço e permanecer com os dentes presos ao próprio pescoço até o dia em que eu... ${ }^{96}$

\footnotetext{
${ }^{91}$ PAULA, José Agrippino de. Lugar público. Civilização Brasileira, Rio de Janeiro, 1965, p. 111.

92 Idem, ibidem, p. 26 e 43.

${ }^{93}$ Idem, ibidem, p. 111.

${ }^{94}$ Idem, ibidem, p. 48, 53 e 54.

${ }^{95}$ Idem, ibidem, p. 180.

${ }^{96}$ Idem, ibidem, p. 180-181.
} 
Características como a indolência apontada pelo pai parecem afetar a própria relação pai e filho, além das memórias que o filho tem do progenitor. E, mesmo diante da lembrança familiar que poderíamos supor a mais forte, a morte do pai, o narrador permanece apático. Ele parece incapaz de emoção ou de envolvimento.

Uma concepção um pouco estranha a respeito dos dois determinantes fundamentais: suponhamos que o fato de ter morrido o pai aos dezenove anos nada signifique. Ele considera um fato banal. Cumpre através do ato que não tem nenhuma relação com o sofrimento real pelo crime cometido... um gesto que apaga as formas fúnebres. Destruo o aspecto da indiferença num sopro. Um desenho feito a giz num quadro negro. Apago com a mão. E no instante em que o caixão descia para a cova, a boca procurava esconder o sorriso. ${ }^{97}$

Além da não significação ou da insignificância que representa a morte do pai, há um último ato de crueldade do protagonista. Esse ato, o sorriso disfarçado, parece desproporcional diante das memórias, mesmo as mais severas, que ele tem do pai. O gesto é quase insuportável. Se o leitor tem alguma simpatia ou condolência com o narrador, o sorriso deste diante do pai enterrado contribui para desfazer essa sensação.

\section{A presença da escrita}

Um dos elementos centrais da narrativa de Lugar público é a presença da escrita. A escrita revelada no romance reforça o deslocamento da realidade e afasta o livro do modelo realista, aproximando-o de uma "literatura de criação". Segundo Claudia Amigo Pino, essa literatura

[...] Se refere ao seu próprio processo de criação. De certa maneira, toda obra integra parcialmente as características de sua produção, ou em forma de

\footnotetext{
${ }^{97}$ Idem, ibidem, p. 20.
} 
metáfora, ou como visão do mundo, do trabalho. Porém, há um determinado tipo de narrativa que escapa ao efeito mimético da literatura e revela que aquilo que estamos lendo não constitui um universo paralelo; trata-se de uma construção de um autor, que por sua vez só se completa na presença do leitor. ${ }^{98}$

Alguns dos procedimentos, como por exemplo o mise em abyme, são comuns nesse tipo de narrativa, também chamada “"metaficção', ou seja, uma ficção sobre a ficção".

O crítico norte-americano Robert Stam definiu a metaficção como narrativa autorreflexiva ou anti-ilusionista, já que, através da reflexão sobre si mesma, destruiria a ilusão artística na qual o leitor de um romance ou o espectador de um filme são imersos. 'Enquanto a arte ilusionista procura causar a impressão de uma coerência espácio-temporal, a arte anti-ilusionista procura ressaltar as brechas, os furos e as ligaduras do tecido narrativo'.

Para o autor, a grande estratégia dessa narrativa é a descontinuidade, que pode apresentar-se de distintas maneiras como a simples interrupção, a história dentro de uma história, a referência a outro texto etc. Essa descontinuidade obrigaria o leitor a se ver como cúmplice da ilusão artística e, nesse mesmo momento, esta ilusão estaria destruída e a reflexão sobre a narrativa, instaurada. ${ }^{99}$

Nas unidades mínimas de significação de Lugar público, nos parágrafos ou blocos que constituem os relatos, haverá inúmeras reflexões ou exposições do ato da escrita, como vimos quando comentamos a presença da chuva na narrativa. São trechos em que o narrador trabalha, ou seja, escreve uma narrativa que, ainda que isso não seja explicitado em momento algum, pode bem ser o livro que o leitor tem nas mãos. Esses blocos, sem continuidade como todos os demais relatos, também são descontínuos no sentido da exposição de Claudia Amigo Pino, e colaboram para a destruição da ilusão de real da narrativa.

\footnotetext{
${ }^{98}$ PINO, Claudia Amigo. A ficção da escrita. Cotia, SP: Ateliê Editorial, 2004, p. 34-35.

${ }^{99}$ Idem, ibidem, p. 35-36.
} 
Dissemos como muitos dos relatos memorialísticos de Lugar público são autobiográficos e ressaltamos que, ainda que não existam marcadores temporais no texto, muitos desses relatos se assemelham ao diário. ${ }^{100}$

Em uma entrevista nos anos 2000, o próprio autor disse que:

Lugar público se aproxima mais do romance, embora eu tenha que reconhecer que se aproxima também do gênero do diário porque partes do diário entraram no livro. Então, sobre problemas do gênero em literatura eu fiquei um pouco misturado. ${ }^{101}$

A rigor, todo o romance pode ser lido como um diário em que, além de episódios cotidianos e corriqueiros, o narrador rememora acontecimentos, descreve cenas urbanas e compõe cenas fantásticas. Na edição do livro, na "montagem" dos blocos, o autor se apropriou do material que mantinha. Vejamos um caso.

Deixei de lado a prova. Não sei quando vou iniciar. Vencer a última etapa do curso. Formado arquiteto. Formado arquiteto. Qual a razão de tudo isto? É uma afirmação que eu fiz para a minha mãe no leito de morte de meu pai. Meu pai agonizante, minha mãe insiste chorando para que eu seja arquiteto. Estou no fim do caminho. Mais alguns passos; somente alguns passos. Mesmo dois ou três passos trôpegos servirão para transpor a linha de chegada. Espero não cair ao solo... somente estes três ou quatro passos... tenho que aguentar o corpo... somente estes três ou quatro passos... depois... poderei cair sem força, corpo inerte e extenuado, respiração ofegante, lábios trêmulos. ${ }^{102}$

\footnotetext{
${ }^{100}$ Sabemos que José Agrippino manteve um diário pelo menos entre o final da década de 1950 e o início dos anos 1960. Realizações artísticas podem corresponder à experiência, ainda que, no território complicado que envolve vida e obra, nada possa ser demonstrado com exatidão. A esse respeito, Nádia Batella Gotlib (2015) disse: "não se pode negar que há... coincidências".

${ }^{101}$ Programa Lugar Reservado, Sesc TV, 2005.

${ }^{102}$ PAULA, José Agrippino de. Lugar público. Civilização Brasileira, Rio de Janeiro, 1965, p. 98.
} 
É essa personagem, supomos, que narra os demais acontecimentos do livro. Mesmo o que é mais íntimo no romance, as memórias do narrador, presta-se não à expiação, mas à observação pura.

Maurice Blanchot tratou da relação dos escritores com o diário. Seus comentários nos serão úteis para tratarmos da relação do narrador de Lugar público com o gênero. "O Diário não é essencialmente confissão, relato na primeira pessoa. É um Memorial", ${ }^{103}$ diz o crítico francês. Ainda que exista a função confessional no diário de Lugar público, é o memorial que vai prevalecer nesses relatos. Segundo Blanchot,

O diário assinala que aquele que escreve já deixou de ser capaz de pertencer ao tempo pela firmeza ordinária da ação, pela comunidade do trabalho, do ofício, pela simplicidade da fala íntima, a força da irreflexão. Já deixou de ser realmente histórico mas tampouco quer perder tempo e, como não sabe mais o que escrever, escreve pelo menos a pedido de sua história cotidiana e de acordo com a preocupação dos dias. [...] ${ }^{104}$

Nesse memorial, o narrador trabalha suas memórias e confissões aos olhos do leitor. Entre tantas descrições, ele apresenta também o próprio ato de escrever, o "estar-ali da linguagem literária, uma espécie de brancura (mas não uma inocência)”, como queria Roland Barthes. ${ }^{105}$ Ou então os momentos que envolvem o ato da escrita. O sair de si para ver-se de fora é realizado ao longo de todo o livro.

Se isolarmos o material do romance, em uma distribuição equilibrada de todos os relatos, agrupando-os sob temáticas familiares, veremos que são justamente os relatos pessoais do narrador que dão mais força ao livro. Isso acontece porque são esses os relatos que mais apresentam conflitos internos. De fato, o livro se realiza, acontece exatamente nesses relatos íntimos e confessionais do narrador.

\footnotetext{
${ }^{103}$ BLANCHOT, Maurice. O espaço literário. Tradução de Álvaro Cabral. Rio de Janeiro: Rocco, 2011, p. 20.

${ }^{104}$ Idem, ibidem, p. 21.

105 BARTHES, Roland. "Literatura e metalinguagem”. In: Crítica e verdade. Tradução de Leyla PerroneMoisés. São Paulo, Perspectiva, 2013a, p. 28.
} 
Mesmo não havendo hierarquia entre as centenas de histórias, podemos apontar os relatos autobiográficos e memorialísticos como uma narrativa que se sobrepõe às demais não pela maneira como são apresentados, já que, como dissemos, também eles são igualados em valor ao resto, mas pela tentativa de aprofundamento do indivíduo - ainda que também esse aprofundamento mal se realize.

Além das descrições que faz em primeira pessoa, há o narrador que se refere a si mesmo como "Ele", ou seja, que se vê de fora. Ainda que nessas histórias se note um grande grau de realismo, em diversos momentos o diário presta-se a descrições que lembram transcrições de sonhos.

$\mathrm{Na}$ apatia do narrador, a escrita parece ser a única possibilidade de escape. $\mathrm{O}$ ato de escrever, no livro, surge como necessidade imperiosa ao narrador, quase uma saída. A revelação do processo da escrita na história é uma das características do Novo Romance. Sandra Nitrini recorre a Jean Ricardou ao afirmar que

[...] Dois componentes entram em situação conflitiva em todos os romances, para dizer que: a ilusão referencial e a ilusão de literariedade, uma predomina nos romances tradicionais, e outra, nos novos romances, mas nunca monopolizando um só domínio.

O predomínio da ilusão de literariedade nos novos romances lança uma nova dimensão temporal na narrativa: o tempo da escritura introduz-se no tempo da ficção e acaba por suplantá-lo, em outros termos, o tempo da enunciação prevalece sobre o tempo do enunciado. ${ }^{106}$

De acordo com Nitrini, no Novo Romance vai haver um confronto entre os dois eixos, com predomínio do eixo temporal do discursivo. Essa sobreposição "traz à luz o próprio processo da escritura que, ao se desvendar, minimiza, de certo modo, a instância da história". ${ }^{107}$ Em Lugar público, a escrita se sobrepõe à história.

\footnotetext{
${ }^{106}$ NITRINI, Sandra Margarida. Poéticas em confronto: Nove, novena e o novo romance. São Paulo: Hucitec; Brasília: INL, Fundação Nacional Pró-Memória, 1987, p 54 (grifos da autora).

${ }^{107}$ Idem, ibidem.
} 
É o diário do narrador que vai contar tudo o que está acontecendo, redimensionando o tempo da narrativa. O tempo da escrita, do discurso, é maior do que o da narrativa. As análises que o narrador faz de seu processo tendem a ser sempre mais duradouras do que as cenas que ele nos mostra. É importante observarmos, porém, que nem sempre essa escrita precisará ser revelada. $\mathrm{O}$ que queremos frisar é que às vezes uma cena que ocorre sem a presença do narrador pode estar sendo escrita aos nossos olhos no diário. A escrita em Lugar público nem sempre é explícita, mas, pela presença do diário, podemos supor que todo o romance está sendo escrito nele, mesmo quando a forma apresentada pelo discurso não seja exatamente a de um diário.

Há uma cena que revela a presença da escrita e dá a dimensão de sua importância na narrativa.

Eu estou preso ao imediato. Este instante. Este instante. Os ruídos isolados da máquina de escrever. O presente faz com que eu ... a voz da bibliotecária. Escrevendo com uma caneta esferográfica de tinta azul, presa entre os dedos, os dedos ligados à mão, a mão ligada ao antebraço, o antebraço ligado ao braço, o braço ligado ao ombro, o ombro ligado ao tórax, o tórax ligado ao tronco, o tronco ligado ao corpo, o corpo ligado à cadeira, a cadeira ligada ao solo, o solo ligado à terra, a terra ligada ... Um desprendimento do passado e uma inexistência do futuro. A bibliotecária sorri. O importante é preencher a folha em branco. As palavras cobrem a folha em branco. Movimentar a mão para que a mão escreva. ${ }^{108}$

A passagem é quase uma metáfora da situação do narrador no mundo. Ainda que prisioneiro do imediato, somente escrevendo ele se sente ligado e pode se ligar ao mundo. É por meio da escrita que ele se prende a algo, é a escrita, objetiva na maioria dos casos, como nas descrições, mas produto de uma subjetividade, que apreende e acaba por configurar a realidade do mundo e da narrativa.

Daí as passagens em que o narrador é levado a refletir sobre o próprio ato da escrita. E também esse ato será questionado, por parecer insuficiente.

${ }^{108}$ PAULA, José Agrippino de. Lugar público. Civilização Brasileira, Rio de Janeiro, 1965, p. 175. 
Folheio o que eu escrevo à procura de um número infinito de palavras, quase que desejo contá-las para que o resultado de meu trabalho apareça sob a forma de número. ${ }^{109}$

As frases que escrevo são de três tipos: uma que pretende dizer algo, outra que não pretende dizer e uma terceira que encobre o que deve ser dito. $[\ldots]^{110}$

Além disso, haverá pelo menos um momento em que, durante o ato, ele deixará de escrever para se ver de fora e somente então voltar a escrever.

Ele estava sentado escrevendo. Levantou-se e largou a caneta de lado. Escuro. Fechou os olhos. Sentiu o escuro. Sentiu ser envolvido pelo escuro. Desapareceram a mesa, os papéis, a caneta. Ele deu dois passos e tocou com o dedo no muro frio. Granitos retangulares. A umidade penetrava pelas frestas. Seguiu com a ponta dos dedos as arestas dos blocos. Abriu os olhos. O escuro o envolvia como uma substância. Fechou novamente os olhos e seguiu tateando com o corpo colado à parede e as mãos acariciando a superfície fria de pedra. Elevou a mão esquerda e sentiu com os dedos a oposição do outro muro de pedra. Passou a mão pela intersecção formada pelos dois muros. Definiu com um gesto a vertical formada pela intersecção dos dois muros. Afastou-se e permaneceu alguns instantes ouvindo um ruído longínquo. Algumas gotas batiam insistentes na pedra. Abriu os olhos. O escuro o envolvia como uma substância. Fechou novamente os olhos e seguiu tateando com o corpo colado à parede e as mãos acariciando a superfície fria da pedra. Elevou a mão esquerda e sentiu a oposição do terceiro muro de pedra... e do quarto muro de pedra. Ele deu dois passos para trás afastandose do muro. Um vento frio soprava de cima. Sentou e continuou a escrever. ${ }^{111}$

\footnotetext{
${ }^{109}$ Idem, ibidem, p. 47, 151.

${ }^{110}$ Idem ibidem, p. 182.

${ }^{111}$ Idem, ibidem, p. 34.
} 
A exposição nos faz pensar que todo o livro está sendo escrito no diário em que o autor recolhe, aqui e ali, suas lembranças, recriando, reconstruindo os acontecimentos. É isso que o sustém, por isso ele senta-se e continua. A escrita, como todo o resto, é vista às vezes como impossibilidade, mas é nela - e somente nela - que o narrador vislumbra a possibilidade de se realizar. Por isso, podemos supor que é através dela que ele finalmente penetra o mundo entregando-nos o livro que estamos lendo.

Mas nem mesmo escrever, a concentração exigida pelo ato, é capaz de aplacar a angústia e a impossibilidade. A própria escrita por vezes fracassa.

Sem o que escrever. O esquecimento das obras inúteis. Fim de um domingo nulo. Zero e zero. Anulação dos seres, dos desejos humanos, das construções humanas. Falta de ligação aos livros. ${ }^{12}$

A minha pobreza literária é o medo de enfrentar a minha pobreza absoluta. Contemplar de frente o orifício circular e vazio da própria incapacidade. Incapacidade para qualquer ação humana. Inércia total. Continuo achando a ... continuo adiando inúmeras coisas. ${ }^{113}$

A diversidade de relatos do livro dá a dimensão desse indivíduo fragmentado, de uma consciência partida que está prestes a explodir diante da impossibilidade.

Existem dias em que eu estou a ponto de explodir como uma bolha de sabão. Uma explosão sem ruído. ${ }^{114}$

A possibilidade da explosão é, também, nula, muda e sem efeito. A realização, em Lugar público, parece ser impossível. A ação é impossível no sentido de transformação. Do mundo, do indivíduo, do narrador e da própria narrativa. A atitude do narrador revela uma incompreensão do mundo ao redor, uma incapacidade de apreendê-lo. Esse é o herói possível

\footnotetext{
112 Idem, ibidem, p. 150.

${ }^{113}$ Idem, ibidem, p. 193.

${ }^{114}$ Idem, ibidem, p. 134.
} 
do romance. Por isso, toda ação do narrador-protagonista e de seus amigos parece fadada ao fracasso.

Entretanto, o ato de escrever faz o livro existir. A escrita torna tudo possível, até mesmo a possibilidade de tudo questionar, inclusive a si mesma. Ela é testada de diversas maneiras na narrativa até o ponto de se revelar. Escrever é a saída encontrada pelo narrador. Há um trecho de um ensaio de Maurice Blanchot que trata da escrita como solidão essencial, que parece ter sido escrito sobre o narrador de Lugar público. As palavras do crítico e escritor sobre a anulação do tempo e a solidão da escrita, ou seja, sobre o ato da escrita como deslocamento, se adéquam à escrita revelada do romance de Agrippino.

Escrever é entregar-se ao fascínio da ausência de tempo. Neste ponto, estamos abordando, sem dúvida, a essência da solidão. A ausência de tempo não é um modo puramente negativo. É o tempo em que nada começa, em que na iniciativa não é possível, em que, antes da afirmação, já existe o retorno da afirmação. Longe de ser um modo puramente negativo é, pelo contrário, um tempo sem negação, sem decisão, quando aqui é igualmente lugar nenhum, cada coisa retirada em sua imagem e o "Eu" que somos reconhecese ao soçobrar na neutralidade de um "Ele" sem rosto. O tempo da ausência de tempo é sempre presente, sem presença. Esse "sem presente" não devolve, porém, a um passado. Teve outrora a dignidade, a força atuante do agora; dessa força atuante ainda é testemunha a lembrança, a lembrança que me liberta do que de outro modo me convocaria, me liberta proporcionando-me o modo de invocá-la livremente, de dispor dela segundo a minha intenção presente. [...] $]^{115}$

Em todo o romance, seja na consciência bipartida do narrador, nas descrições das cenas que ele observa a distância ou naquelas em que se envolve ao lado de seus companheiros, temos uma alegoria da impenetrabilidade ou daquele aqui que é igualmente lugar nenhum de que fala Blanchot.

${ }^{115}$ BLANCHOT, Maurice. O espaço literário. Tradução de Álvaro Cabral. Rio de Janeiro: Rocco, 2011, p. 21. 
O “Eu”, então, suplica por algo que não tem. "Não resta nenhum canto de parede onde eu possa me esconder. Para continuar eu dependo de um fragmento de fé e esperança. Um insignificante fragmento de fé e esperança". ${ }^{116}$ Ele parece saber que, sem isso, corre o risco de dispersar, se dissolver ou de explodir como uma bolha de sabão. Nesses momentos, a escrita é interrompida, e o "Eu" se aproxima e se identifica com os loucos.

Quando os loucos passam por uma crise violenta, os alienistas fazem com que aqueles se integrem numa tarefa qualquer; pintar um quadro com os dedos; construir uma cesta, um desenho... o objetivo é tranquilizar. Eles, os loucos, misturam as tintas com os dedos e lançam aos quadros as figuras... Não grito. Nestes dias o meu desejo seria o de lançar gritos lancinantes de dor e angústia. Não grito. Impossibilitado de escrever nestes dias, minhas mãos tremem; impossibilitado de escrever. ${ }^{117}$

Em seu isolamento, seja no alojamento estudantil, em bibliotecas ou no apartamento em que escreve, o narrador-protagonista compõe histórias sobre ou passadas ao lado de seus amigos, dá voz à memória e convive com fantasmas o medo do fracasso e da dispersão que, no extremo, ele percebe, pode se transformar em loucura. Então, ele luta para se concentrar em si mesmo, com o prejuízo de não se sociabilizar. Daí o seu isolamento.

O esforço que eu realizo para me concentrar em mim mesmo me coloca fora do mundo dos vivos. Não percebo o que me envolve e raramente ouço o que os outros dizem. Eu devo me concentrar em mim mesmo. Mas eu sinto a sufocação que este esforço realiza em mim. Enquanto os outros tratam de obter as coisas... mas eu devo escapar. Eu finalizo o meu trabalho e peço umas férias de mim mesmo. Eu penso que se eu permanecer neste estado de tensão mais

\footnotetext{
${ }^{116}$ PAULA, José Agrippino de. Lugar público. Civilização Brasileira, Rio de Janeiro, 1965, p. 178

${ }^{117}$ Idem, ibidem, p. 186.
} 
alguns dias vou explodir a minha loucura pelas ruas. Mas eu devo continuar mordendo obsessivamente. Não devo esquecer que o que me amedronta é a dispersão. ${ }^{118}$

O colocar-se fora do mundo dos vivos não inclui o narrador entre os mortos, mas ele sabe que o resultado de seu esforço de concentração pode levá-lo a perder-se. Parece que é exatamente o resultado desse esforço, um esforço permanente, que era visto erroneamente pelo pai do narrador como egoísmo. Graças ao diário, sabemos que não se tratava apenas disso. O esforço do narrador para concentrar-se em si, o medo que ele tem e que o faz isolarse é o medo da dispersão e da loucura.

Vimos na introdução deste estudo como havia na geração de Agrippino uma associação com a loucura. Em estudo sobre o tema, Peter Pál Pelbart observou que, "por trás da distinção [...] entre o saber clínico e a valorização estética [...] paira uma disjunção maior, histórica, já quase inconcebível para nós - a diferença entre Loucura e Desrazão". ${ }^{119}$ O filósofo nomeou a desrazão como “o Fora”. Essas duas noções de loucura, a clínica e a “desrazão", estarão presentes na obra do autor.

Um bom exemplo da desrazão em Lugar público é um relato formatado como um diálogo de teatro que lembra muito as peças de Samuel Beckett. Nele, o narrador coloca em cena um "Ele" e um "Ele mesmo" como se, no fundo, estivesse produzindo um diálogo entre os dois narradores do livro, em que o "Eu" se reconhece no "Ele".

Ele: Eu estou aqui esperando.

Ele mesmo: E quase sempre nós nos encontramos.

Ele: Quase sempre.

Ele mesmo: E estes mortos?

Ele: É a minha bagagem. São os meus companheiros.

Ele mesmo: Estou um pouco fatigado.

Ele: Sono?

\footnotetext{
${ }^{118}$ Idem, ibidem, p. 88.

${ }^{119}$ PELBART, Peter Pál. Da clausura do fora ao fora da clausura, loucura e desrazão. São Paulo: Brasiliense, 1989, p. 14 e 15.
} 
Ele mesmo: Não. Não é sono.

Ele: Pode ser que...

Ele mesmo: É verdade; pode ser.

Ele: Eu sei.

Ele mesmo: Por que você não enterra os seus mortos?

Ele: Não é preciso. Eles não apodrecem. ${ }^{120}$

O diálogo absurdo torna patente a apatia do narrador e a sua incapacidade de avançar. O vagar sem rumo, sem motivo e sem esperança das personagens configura uma existência com significado vazio, em que apenas a memória persiste, sempre de modo fragmentário e por vezes delirante. Parece que, depois de muito cavar, as personagens não chegam a lugar nenhum. Esse parece ser o lugar indefinido de Lugar público. Por acúmulo, o método de agrupamento das histórias que tantas vezes soa apático, em determinadas situações atinge momentos dramáticos.

Em ensaio sobre o romance moderno, ${ }^{121}$ Anatol Rosenfeld comenta, a partir do campo das artes, o fenômeno da "desrealização", que "se refere ao fato de que a pintura deixou de ser mimética, recusando a função de reproduzir ou copiar a realidade empírica, sensível”. O pensamento do crítico demonstra como, nas diversas expressões da pintura moderna, o ser humano

é dissociado ou 'reduzido' (no cubismo), deformado (no expressionismo) ou eliminado (no não-figurativismo). $O$ retrato desapareceu. Ademais, a perspectiva foi abolida ou sofreu, no surrealismo, distorções e 'falsificações'. ${ }^{122}$

\footnotetext{
${ }^{120}$ PAULA, José Agrippino de. Lugar público. Civilização Brasileira, Rio de Janeiro, 1965, p. 40.

${ }^{121}$ ROSENFELD, Anatol. "Reflexões sobre o romance moderno". In: Texto/Contexto I. $5^{\text {a }}$ edição. São Paulo: Perspectiva, 1996.

${ }^{122}$ Idem, ibidem, p. 77 (grifos do autor).
} 
Para Rosenfeld, a perspectiva seria um "recurso para a conquista artística do mundo terreno, isto é, da realidade sensível". Ela seria uma "característica típica de épocas em que se acentua a emancipação do indivíduo", como, por exemplo, durante o Renascimento. Com ela, o mundo seria relativizado e constituído a partir de uma consciência. "Um mundo relativo é apresentado como se fosse absoluto".

A pintura moderna, que deforma o ser humano, assim, nega a perspectiva “ilusionista” e “põe em dúvida a 'visão' do mundo que se desenvolveu a partir do Renascimento". O indivíduo moderno, por sua vez, já não tem a "fé renascentista na posição privilegiada da consciência humana em face do mundo e não acredita mais na possibilidade de, a partir dela, poder constituir uma realidade que não seja falsa”, diz o crítico.

Desse modo, as mudanças provocadas nessa consciência e sentidas na pintura manifestam-se, também, no romance moderno no momento em que autores como "Proust, Joyce, Gide, Faulkner começaram a desfazer a ordem cronológica, fundindo passado, presente, e futuro".

Inicialmente introduzida na arte para "dominar o mundo terreno", a perspectiva tornase "símbolo do abismo entre o homem e o mundo, símbolo dessa cisão e distância que o poeta G. Benn, chamou de 'catástrofe esquizoide"”. Nas palavras de Rosenfeld, essa catástrofe corresponderia à "fragmentação da unidade original" e suscitaria "uma verdadeira angústia". E precisamente esse processo justificaria o estado experimental do romance.

[...] Gerações inteiras de artistas e intelectuais procuram reencontrar uma posição estável e essa procura, resultado e causa de uma instabilidade cada vez maior, exprime-se no estado de pesquisa e experimentação do romance, cujos autores tentam retificar as enfocações tradicionais; e manifesta-se, principalmente, no desejo de fugir para um mundo ou uma época em que o homem, fundido com a vida universal, ainda não conquistara os contornos definitivos do eu, em que não se dera ainda o pecado original da "individuação" e da projeção perspectívica. ${ }^{123}$

\footnotetext{
123 Idem, ibidem, p. 88.
} 
Essa tentativa de fuga para uma época remota estaria na base da utilização da mito no romance contemporâneo, aspecto que desenvolveremos no capítulo em que tratamos de PanAmérica. Por hora, podemos ver como a perspectiva, de acordo com Rosenfeld, estaria na origem de uma crise da representação que obriga o artista contemporâneo a regredir em busca do elementar. Tal regressão, segundo o crítico, fundamentaria as vanguardas.

Esse culto do arcaico, esta glorificação do início e do elementar são típicos justamente para as vanguardas mais requintadas. O intelectual, o "esquizóide" neurótico, dissociado entre os valores em transição, enquanto revela essa fragmentação nas suas personagens desfeitas e amorfas, exprime nesta mesma decomposição do indivíduo a sua esperança de, chegado à substância anônima do ente humano, poder vislumbrar a integração no mundo elementar do mito. ${ }^{124}$

A agudez do crítico o leva a identificar precisamente nesse movimento de regressão a origem comum de algumas experimentações estéticas daquele período.

Daí a glorificação dos deuses passados e o misticismo orientalizante de tantas "Beat Generations" e adeptos do Zen, arautos fervorosos de uma unidade aperspectívica em que não há 'pontos de fuga' e em que os seres se confundem e apagam na "união mística" plana, que é apenas o reverso "dialético" dos imensos espaços vazios, feitos de pesadelo e angústia, dos surrealistas: perspectiva deformada que encontramos também nos romances de Kafka. ${ }^{125}$

Salvo na liberdade que pressupõe a escrita, que lhe permite relatar acontecimentos fantásticos, o narrador de Lugar público está preso ao real, ele não tem possibilidade de escapar ou de projetar um novo mundo onde será superior à natureza. É precisamente esse o movimento que ocorre em PanAmérica, um romance mitológico.

\footnotetext{
${ }^{124}$ Idem, ibidem.

125 Idem, ibidem, p. 89.
} 
Ainda que Lugar público não se enquadre nessa categoria, há, como vimos, momentos que o livro dela se aproxima justamente por fazer a regressão. Esses momentos são principalmente os associados à loucura estética, à desrazão. Esta é fantástica. A outra, a loucura clínica, está na origem de toda a angústia do narrador. Na configuração do romance, será essa a loucura responsável pela irrupção da desrazão nos relatos. O movimento antecipa o método que será explorado em PanAmérica. Nesse romance, Agrippino superará o realismo e situará toda a narrativa numa esfera mitológica e fantástica.

Quanto a Lugar público, os blocos diversos permanecerão presos ao universo real, o único possível, que faculta ao narrador a possibilidade de fuga unicamente pela imaginação. Ao final do livro, as centenas de relatos nivelados na superfície parecem camadas de cebola que, retiradas, deixam no lugar que uma vez ocuparam apenas o vazio. 


\section{CAPÍtULO 2}

\section{PANAMÉRICA EPOPEIA POP}

$\mathrm{O}$ anjo de lança-chamas queimava com uma nuvem de fogo as gigantescas arraias que voavam em pânico cobertas de chamas.

PanAmérica

\section{Poética do romance}

Em maio de 1966, a Revista Civilização Brasileira publicou um inquérito sobre o romance urbano feito pelo escritor João Antônio com jovens autores do período. Os participantes foram Carlos Heitor Cony, Sylvan Paezzo, João Marthins, Esdras do Nascimento, Thereza Christina e José Agrippino de Paula. ${ }^{126}$

As perguntas giravam em torno de influências, técnicas e pontos de vista sobre a literatura por eles produzida. Em contraste com os demais autores, as respostas de Agrippino surpreendem pela concisão. Ainda que tivesse estreado no ano anterior, sua fala revela um autor consciente de seus recursos e quase indiferente diante da necessidade de se situar entre seus pares. Ele responde direta e brevemente, evitando formulações muito longas.

Logo na primeira questão, "por que” escreviam romance, diz: "É difícil dizer. Eu não escrevo um livro ou romance, simplesmente escrevo uma ou duas páginas". Mais adiante, questionado sobre o que é o romance, Agrippino dá uma explicação adequada à evolução do gênero ao longo do século XX: "um livro de mais de 100 páginas em que se escreve na capa: romance". 127

126 ANTÔNIO, João. "Inquérito: o romance urbano". In: Revista Civilização Brasileira n 7, Rio de Janeiro, Civilização Brasileira, maio de 1966.

${ }^{127}$ Idem, ibidem, p. 197. As palavras de Agrippino ecoam as de Edward M. Forster, que recorreu à definição de M. Abel Chevalley para o gênero: “"uma ficção em prosa com uma certa extensão' (une fiction em prose d'une certaine étendue). Isso é o suficiente para nós, mas talvez possamos ir além e acrescentar que a extensão não deveria ter menos de 50.000 palavras. (FORSTER, Edward Morgan. Aspectos do romance. Tradução de Maria Helena Martins. $2^{a}$ edição. São Paulo: Globo, 1998, p. 9-10.) 
Juntas, as declarações podem ser consideradas a "poética" do escritor José Agrippino de Paula. A fragmentação, a ruptura com o padrão e a subversão da forma estão no cerne de sua literatura. Por isso, a imagem dos estilhaços, sugerida por Evelina Hoisel, parece muito adequada para caracterizar sua produção.

Já a definição de romance dada pelo autor, ainda que condizente com a evolução do gênero, sobretudo a partir das experimentações originadas no Modernismo, nos obriga a um maior aprofundamento.

Reconhecendo o gênero "como herdeiro das grandes formas épicas do passado", Marthe Robert diz que "o romance, no sentido em que o entendemos hoje, é um gênero relativamente recente, mantendo laços apenas muito frouxos com a tradição de que se originou". ${ }^{128}$ A partir de estudos de Dom Quixote e de Robinson Crusoe e diante das diferentes formas que a prosa de ficção longa adquiriu, a crítica francesa propôs a ideia de "gênero colonizador".

O extraordinário destino percorrido em tão pouco tempo pelo romance resulta na verdade de seu caráter arrivista, pois, ao examinarmos de perto, ele o deve sobretudo a conquistas nos territórios de seus vizinhos, os quais ele pacientemente absorveu até reduzir quase todo o domínio literário à condição de colônia. [...] $]^{129}$

A estudiosa recorre ao famoso questionamento em que Maupassant arrola diversos livros e autores de épocas distintas e em quase tudo diferentes para confrontar o crítico que “ainda ousa escrever "isto é um romance, aquilo não é"” (p. 15). A partir dessa provocação de Maupassant, Marthe Robert continua.

Aqui, é evidente, o romancista tem absoluta razão contra seus críticos - a multiplicidade de títulos, por mais cosmopolitas e díspares, que pudéssemos acrescentar à sua lista só faria fortalecer sua refutação. Pois atualmente poderíamos perguntar ao crítico o que vê em comum entre $O$

\footnotetext{
${ }^{128}$ ROBERT, Marthe. "Por que romance?” In: Romance das origens, origens do romance. Tradução de André Telles. São Paulo: Cosac Naify, 2007, p. 11.

${ }^{129}$ Idem, ibidem, p. 12.
} 
processo e ... E o vento levou, entre Lolita e Anna Kariênina, entre Não mandem orquídeas para Miss Blandish e $O$ caminho de Swann ou $O$ ciúme, de Robbe-Grillet, fazendo-lhe contudo observar que essas aproximações, tomadas ao acaso no catálogo mais corriqueiro da enorme biblioteca universal, não são de forma alguma as mais grotescas, nada disso. [...] ${ }^{130}$

Em seguida, ela conclui que, "para o romancista, portanto, o romance tira sua força precisamente de sua absoluta liberdade". ${ }^{131}$

Foi justamente a partir dessa liberdade que Agrippino produziu sua literatura. As proposições de Marthe Robert nos ajudam a pensar na concepção que o escritor tinha do gênero e a entender a classificação que ele propôs para seu segundo livro.

O método de composição e a proximidade da publicação aproximam Lugar público e PanAmérica. Essas obras, a despeito do que guardam de original e característico, utilizam procedimentos comuns como, por exemplo, a narração de trechos que funcionam como blocos autônomos (os parágrafos em Lugar público e os capítulos em PanAmérica), a descrição como principal recurso narrativo e a deformação da realidade.

Mas é em PanAmérica que Agrippino vai experimentar alguns desses procedimentos de modo mais intenso. Por isso, o livro ocupa um lugar de destaque na produção do escritor. Desde a classificação do romance até a absoluta ruptura com praticamente todas as convenções do romance, esse será um livro de excesso, de delírio e de radicalidade.

A primeira edição de PanAmérica, de 1967, estampava na capa um desenho do artista plástico Antonio Dias. Acima do título havia a classificação: "epopeia” e a folha de rosto

${ }^{130}$ ROBERT, Marthe. "Por que romance?” In: Romance das origens, origens do romance. Tradução de André Telles. São Paulo: Cosac Naify, 2007, p. 16. Nesse mesma linha de raciocínio, Edward M. Forster já tinha dito: "Qualquer ficção em prosa com mais de 50.000 palavras será um romance para os fins destas conferências. E se isso lhes parecer pouco filosófico, procurem uma definição que inclua The Pilgrim's Progress, Marius the Epicurean, The Adventures ofa Younger Son, The Magic Flute, The Journal of the Plague, Zuleika Dobson, Rasselas, Ulysses e Green Mansions ou, em contrário, apresentem razões para a exclusão dessas obras. (FORSTER, Edward Morgan. Aspectos do romance. Tradução de Maria Helena Martins. 2a edição. São Paulo: Globo, 1998, p. 10.)

${ }^{131}$ Robert, op. cit., p. 15.

${ }^{131}$ Idem, ibidem, p. 16. 
anunciava, em três linhas: "PanAmérica / epopeia de / José Agrippino de Paula". ${ }^{132}$ De modo paradoxal, não havia em todo o livro qualquer elemento paratextual que fizesse referência ao gênero romanesco - o que, se houvesse, de alguma forma condiria com a definição dada ao gênero pelo autor.

O título publicado, no entanto, não foi o primeiro escolhido. O contrato firmado entre autor e editora trazia o nome provisório de "Divindades eróticas, uma epopeia". ${ }^{133}$ Essa denominação que acabaria relegada continha alguns dos principais elementos constitutivos do livro: os mitos representados pelas "divindades" e o erotismo.

Mas o nome "PanAmérica" era mais adequado ao conteúdo de uma obra que abordava, entre outros temas, as diferentes realidades do continente americano e as relações culturais entre sociedades tidas como desenvolvidas e subdesenvolvidas. Ou, para usarmos a classificação da época, entre o Primeiro e o Terceiro Mundo. O romance problematiza uma realidade complexa e conflitante. Nisso, o livro tinha muitas semelhanças com a peça As Nações Unidas, escrita por Agrippino provavelmente entre a publicação de seus dois romances e ainda inédita em português no Brasil. ${ }^{134}$

A epopeia de Agrippino é composta por vinte capítulos não numerados em que um narrador-protagonista vive aventuras fantásticas ao lado de seres mitológicos contemporâneos. Nessa categoria, inserem-se atores, produtores, diretores de cinema, astros da música pop, personagens de desenhos animados e personalidades políticas de um período situado aproximadamente entre o fim da Segunda Guerra Mundial, quando o cinema se estabeleceu como a maior expressão da faceta cultural do imperialismo norte-americano em escala planetária, e os anos 1960, quando o livro foi escrito. A localização temporal, vamos ver, é importante porque tem relação direta com a existência desses seres na História, mas não na narrativa que, a rigor, não é situada no tempo.

A ação, quando localizada, oscila por lugares contrastantes que mostram a modernidade dos estúdios em Los Angeles e a super civilização de Nova Iorque em oposição

\footnotetext{
132 PAULA, José Agrippino de. PanAmérica. Rio de Janeiro: Tridente, 1967, p. 5.

133 Tivemos acesso ao contrato por meio de Guilherme Henrique de Paula e Silva, que conserva alguns documentos do irmão.

${ }^{134}$ Uma tradução desse texto para o inglês foi publicada no Brasil em uma edição de autor (ver Referências).
} 
à precariedade de uma luta de guerrilha em um lugar indefinido da América Latina. As funções do protagonista reforçam a multiplicidade e os contrastes do continente americano.

O desenho multifacetado de Antônio Dias para a capa da primeira edição expõe a propensão da obra. Nele, se vê fragmentos de símbolos como o brasão de armas dos Estados Unidos, bombas, fumaça, uma arraia voadora, as botas de um guerrilheiro etc. A ilustração revela uma impressionante afinidade entre os desenhos que Dias vinha desenvolvendo no período e o conteúdo do livro de Agrippino.
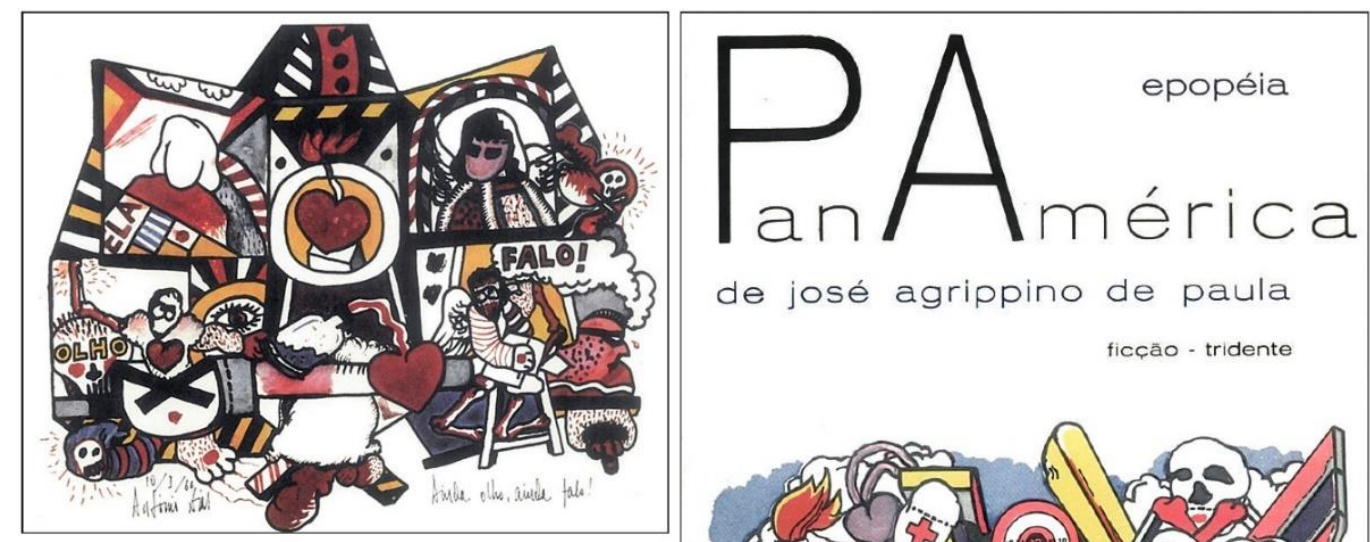

de josé agrippino de paula
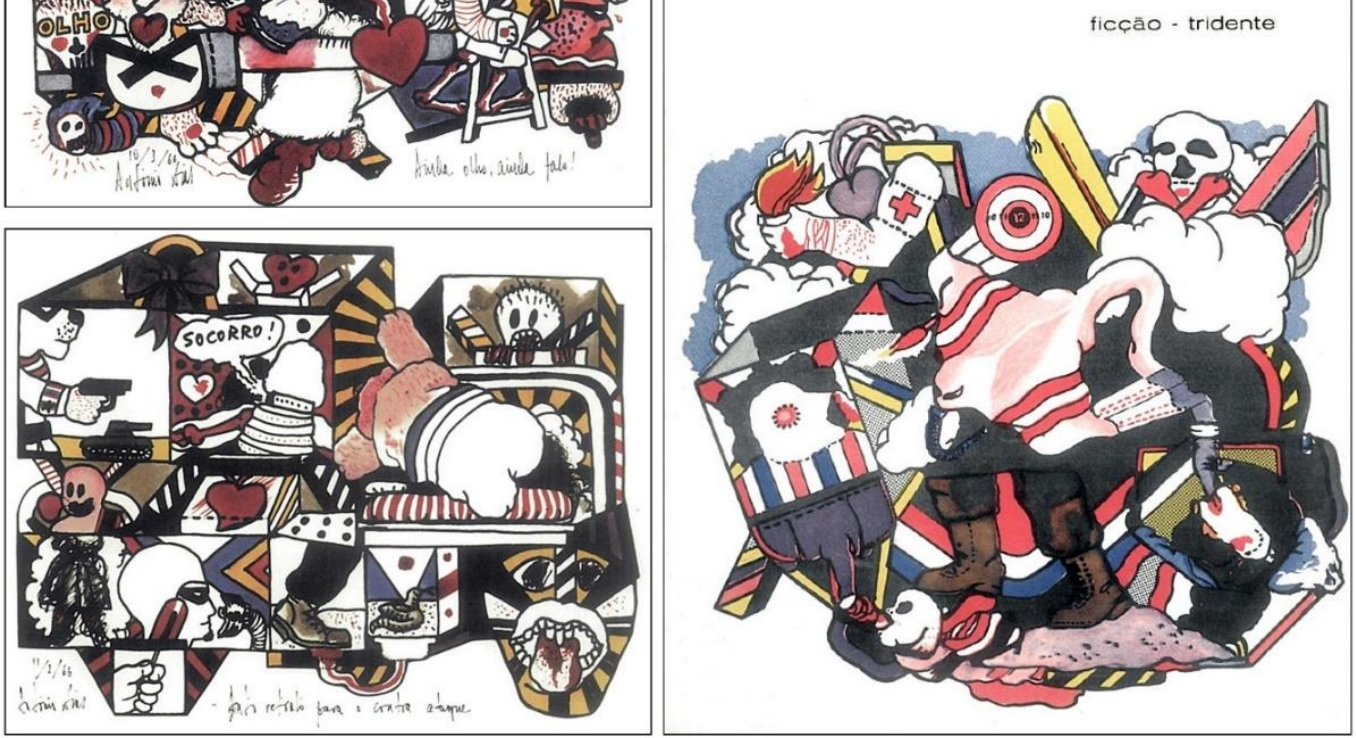

No sentido anti-horário as obras de Antonio Dias Ainda olho, ainda falo e Autorretrato para o contra-ataque, ambas de 1966, e a capa da primeira edição de PanAmérica, de 1967.

Há, nesses capítulos, como que um desfile de personagens históricas divulgadas pela indústria cultural. Elas vêm à cena sem qualquer apresentação ou preparação para logo desaparecerem e ressurgirem de forma inesperada. A velocidade das ações na narrativa configura um universo vertiginoso em que tudo parece escancarado e envolto em uma aura 
de sonho e delírio. Na realidade ficcional, os seres com correspondência histórica interessam como mitos, ou seja, são mais importantes as imagens criadas a partir de suas existências reais do que suas existências propriamente. ${ }^{135}$ Os capítulos se intercalam sem uma relação direta. Podem, a rigor, ser considerados autônomos, ainda que as personagens e suas funções se repitam ao longo da obra. Entretanto, do mesmo modo que os blocos de Lugar público, os capítulos de PanAmérica não têm autonomia, já que é a interligação entre eles o que dá sentido ao romance. O que queremos reforçar é que o material narrado em cada um dos capítulos é autossuficiente. As seções bastam em si e não apresentam uma progressão narrativa que precise ser interrompida em um ponto determinado para ser retomada em outro momento do livro. Não há suspensão das ações.

Essa breve apresentação da estrutura da obra é necessária para que possamos colidilo com a epopeia antiga. Sabemos que nesse gênero clássico eram narrados feitos heroicos e memoráveis de homens lendários que podiam ter em sua origem uma existência histórica. Os acontecimentos passados nessas narrativas contadas em versos representavam a sociedade ou o grupo social a que aqueles homens pertenciam. Ou seja, através de um herói, de um indivíduo, eram narradas e exaltadas as glórias de uma comunidade.

Essas narrativas de origem grega tinham muito de fabular e de extraordinário. Descreviam eventos incomuns que demonstravam a superioridade de heróis tomados como semideuses, seres quase divinos, mitológicos.

A partir da teoria dos gêneros de Hegel, Ligia Chiappini Moraes Leite diz:

Assim, a poesia épica seria aquela em que, do conjunto dos homens e dos deuses, brotaria a dinâmica dos acontecimentos que o poeta deixaria evoluir livremente, sem interferir. Trata-se de uma realidade exterior a ele, com a qual não se identifica a ponto de se envolver com os sentimentos, pensamentos e ações dos caracteres em jogo. ${ }^{136}$

\footnotetext{
${ }^{135}$ Atentos a isso, os editores da primeira edição (ou talvez o próprio autor) recorreram a uma nota que parece de precaução, mas que serve de explicação para o livro: "Qualquer semelhança existente entre personagens da presente epopeia e pessoas da vida real, vivas ou já falecidas, não é pura coincidência. Todavia, essas personagens aparecem no texto do autor como símbolos motivadores do mito, sem relação existencial com o seu verdadeiro valor humano ou com sua vivência espiritual e carnal." (PAULA, 1967, p. 7)

${ }^{136}$ LEITE, Lígia Chiappini Moraes. O foco narrativo. 10ª edição. São Paulo: Ática, 2004, p. 9.
} 
O romance, então, teria como base a epopeia, uma das "grandes formas épicas do passado", ${ }^{137}$ como disse Marthe Robert. Mas, no caso de PanAmérica, ainda que uma coisa esteja ligada à outra, parece que a escolha da classificação pelo autor foi determinada menos pela associação histórica da forma atual do romance com a epopeia antiga do que para evidenciar os aspectos épicos da narrativa. Já na orelha da primeira edição, Mário Schenberg dizia que, em PanAmérica, "José Agrippino nos deu uma epopeia contemporânea do império americano". 138

Escrevendo na metade da década de 1960 em uma sociedade periférica econômica e socialmente e inserida em um contexto de importação de bens de consumo produzidos nos países desenvolvidos industrializados, Agrippino buscou identificar elementos do imaginário daquele momento histórico para criar, em meio a um avanço tecnológico constante e, em si mesmo, feérico e maravilhoso, uma epopeia à altura do homem contemporâneo.

O narrador do romance representa precisamente a sociedade de massa do período, uma sociedade crescente e anônima. Daí ela ser personificada por um ser inominado. Assim como em Lugar público, ele será apenas um “Eu”, agora presente de modo obsessivo em quase todas as cenas do livro e narrando aventuras fantásticas que vão configurar um estranho romance.

O narrador, o modo como a narrativa é conduzida e o conteúdo do material narrado serão elementos fundamentais para conferir ao livro o grau de estranhamento. Em meio à fantasia e ao extraordinário dos acontecimentos, a opção por um narrador-protagonista e a sua presença quase obsessiva na narrativa vão garantir a regularidade do relato.

Evelina Hoisel utilizou a noção de hybris, do teatro grego, definida como "suprema arrogância do homem querer tornar-se igual a um deus", para se referir às características do herói individual do romance.

${ }^{137}$ ROBERT, Marthe. “Por que romance?” In: Romance das origens, origens do romance. Tradução de André Telles. São Paulo: Cosac Naify, 2007, p. 11.

${ }^{138}$ SCHENBERG, Mario. “Apresentação”. In: PanAmérica. Rio de Janeiro, Tridente, julho de 1967. Essa apresentação foi reproduzida nas outras duas edições do livro publicadas até agora, em 1988 e 2001. 
Ao conferir aos seus textos uma conotação trágica, apropriando-se para isso do sentido trágico presente no mundo grego, Agrippino de Paula transfere a noção de hybris do individual para o coletivo. Desse ponto de vista, é a própria sociedade tecnológica a portadora de hybris. Os poderes que o homem adquiriu a partir de suas invenções tecnológicas e a possibilidade de produzir em abundância cada vez mais faz com que ele - e a sociedade como um todo - assuma a feição de um deus. Aqui também a abundância conduz à hybris, a esta à ruína. ${ }^{139}$

Vimos como, em Lugar público, Agrippino recorreu a uma alternância de narradores, modulando os blocos entre a primeira pessoa, com narrador-protagonista, e a terceira pessoa, por meio da utilização de narrador-observador. Naquele caso, a alternância poderia contribuir para a desindividualização do "Eu" que narra. PanAmérica, ao contrário das digressões e das mudanças do foco narrativo de Lugar público, tem mais unidade, é mais coeso.

$\mathrm{O}$ "Eu” que narra terá, na obra, função diversa do "Eu” de Lugar público. Aqui, ele não terá uma consciência remissiva de que falou Anatol Rosenfeld. ${ }^{140}$ Há muito pouco nesse romance daquela crise de consciência que aflige o narrador de Lugar público. O romance quase não apresenta questões psicológicas, nem mesmo em superfície. Ele é pura ação e acontecimento. O "Eu" de PanAmérica terá como que uma superconsciência das coisas. Aquela consciência que ameaçava explodir em Lugar público agora parece explodir de fato, não como bolha de sabão, mas com consequências para o avanço da narrativa rumo ao caos. $\mathrm{O}$ distanciamento do narrador-observador quase não terá lugar nesse livro. O "Eu” será responsável pela maioria das ações e, mesmo quando não é agente, ele acaba envolvido pelos movimentos que descreve.

A introspecção, portanto, desaparece. Ele quase não apresenta traços psicológicos em sua convivência com ídolos de Hollywood como Marilyn Monroe, Marlon Brando e de figuras contemporâneas como o presidente francês Charles De Gaulle, o guerrilheiro Che

${ }^{139}$ HOISEL, Evelina. Supercaos: os estilhaços da cultura em PanAmérica e Nações Unidas. Rio de Janeiro: Civilização Brasileira; Salvador: Fundação Cultural do Estado da Bahia, 1980, p. 115.

${ }^{140}$ Cf. ROSENFELD, Anatol. "À procura do mito perdido: notas sobre a crise do romance psicológico. In: Letras e leituras. São Paulo: Perspectiva, 1994. 
Guevara, o ídolo do beisebol americano Joe DiMaggio, e o grupo de rock Os Beatles, entre outros mitos contemporâneos.

O narrador, ainda que seja extremamente personalizado, não pode ser apreendido como indivíduo. Um pouco como as personagens secundárias de Lugar público, ele não tem características ou traços distintivos. As escassas informações que temos sobre ele não bastam para que possamos traçar-lhe um perfil. Tudo o que sabemos dele é que é cineasta e que trabalha em Holllywood, onde mantém relações com os astros do cinema. Isso acontece pelo menos nos capítulos iniciais e finais do livro. Também é apresentado como soldado e vive aventuras numa guerrilha num país da América Latina. E nada mais.

A opção por um narrador-protagonista reforça o efeito de estranhamento diante de aventuras fantásticas. Se imaginássemos a composição narrada com distanciamento, em terceira pessoa, dificilmente ela teria o mesmo efeito e força expressiva. Sobre a utilização da primeira pessoa nos romances clássicos, Michel Butor, autor associado ao Novo Romance e também teórico, disse:

Um fato característico, a esse respeito, é o de que em todas as mistificações romanescas, cada vez que se tentou fazer passar uma ficção por um documento, como por exemplo Robinson Crusoé ou o Diário do ano de peste de Daniel Defoe, utilizou-se naturalmente a primeira pessoa. Com efeito, se se tivesse utilizado a terceira, ter-se-ia automaticamente provocado a pergunta: "Como é que mais ninguém sabe disso?" O narrador que nos expõe suas vicissitudes responde de antemão a esse inquérito, e remete ao futuro toda verificação: ele nos explica como é que só "um" conhecia aquilo que não "se" conhecia. ${ }^{141}$

Butor se refere à tentativa, por esses autores, de obterem o efeito do real. Em PanAmérica, mais do que obter esse efeito, já que tudo no livro é fantástico, o "Eu", justamente por narrar em primeira pessoa, reforça o estranhamento da narrativa. Ao mesmo tempo, ele aproxima e insere o leitor em suas aventuras, lançando-o na história e não permitindo o distanciamento que seria obtido com a utilização de um narrador-observador.

${ }^{141}$ BUTOR, Michel. Repertório. Tradução de Leyla Perrone-Moisés. São Paulo: Perspectiva, 1974, p. 49. 
Uma vez dentro, o leitor é empurrado por uma sequência vertiginosa de acontecimentos delirantes. Prossegue Butor:

O narrador, no romance, não é uma primeira pessoa pura. Nunca é o autor ele mesmo, literalmente. Não se deve confundir Robinson e Defoe, Marcel e Proust. Ele próprio é uma ficção, mas nessa multidão de personagens fictícias, todas naturalmente na terceira pessoa, ele é o representante do autor, sua persona. Não nos esqueçamos de que ele é igualmente o representante do leitor, exatamente o ponto de vista no qual o autor o convida a colocar-se para apreciar, para saborear determinada sequência de acontecimentos e tirar dela todo proveito. ${ }^{142}$

Assim, o convite em PanAmérica é estranho. Paradoxalmente, há no narrador do romance uma constante exteriorização. Dissemos que, em Lugar público, a narrativa é perpassada por uma impenetrabilidade, uma inapreensão, que as tentativas das personagens, principalmente do narrador, de penetrar o mundo mostram-se falhas. Naquele primeiro livro de Agrippino, isso pode não ser um problema, mas não deixa de criar um incômodo pela maneira como a narrativa é organizada.

Em PanAmérica, o narrador parece tudo querer exteriorizar, dar a ver, mas não em um mundo inapreensível, e sim em um mundo delirante em que tudo ou quase tudo é possível, uma vez que as convenções temporais e espaciais não seguem as regras do mundo fenomenológico normal.

Como em seu primeiro livro, o autor permanece fiel a algumas das técnicas aprendidas do Novo Romance Francês. As descrições de cenas e de acontecimentos de Lugar público dão espaço a descrições objetivas com a função mais definida de situar a ação do narrador. Agrippino leva ao limite a técnica do Novo Romance de evitar a caracterização psicológica das personagens. Praticamente não há psicologia em PanAmérica.

No romance, com exceção do narrador e das personagens animalescas, monstruosas ou gigantes, todas as figuras humanas do livro têm no nome e na função correspondência

\footnotetext{
${ }^{142}$ Idem, ibidem.
} 
com os indivíduos que os inspiraram na realidade. Eles correspondem aos seres reais, mas, na realidade ficcional, não podem ser considerados apenas em sua substância humana, uma vez que sofrerão deformações e metamorfoses.

Enquanto em Lugar público os nomes das personagens secundárias apenas se refiram às personalidades históricas, não tendo com elas qualquer correspondência além da equiparação nominal, em PanAmérica são as personagens históricas (com vivência histórica e não apenas celebrizadas pela História) que irão figurar na narrativa. Além de ostentarem os nomes das personalidades, as personagens serão os próprios seres materiais que entraram para a História. Por isso, nesse romance, o mito terá um papel fundamental.

As personagens de PanAmérica são importantes como seres mitológicos. A imagem de uma atriz como Marilyn Monroe, por exemplo, será mais importante do que o ser carnal que teve uma vivência histórica. $\mathrm{O}$ autor parte do princípio de que suas imagens, propagadas e repisadas pelos veículos de comunicação de massa, extrapolam seus seres. Nessa esfera ampla, sobrepõem-se ao que são de fato. O que interessa no livro não é a "realidade" existencial, mas sim a representação, a realidade simbólica, como advertia a nota de apresentação do livro. ${ }^{143}$

Em grande parte responsável pelo estranhamento proporcionado pela narrativa, a linguagem de PanAmérica é, por princípio, imagética. Com a tendência à exteriorização, o narrador, do mesmo modo que em Lugar público, vai recorrer principalmente à descrição para "mostrar" ações que se sucedem de modo feérico em um estilo sempre direto, vertiginoso e quase agressivo. Cada capítulo do livro é constituído por apenas um parágrafo. Ao contrário de Lugar público, aqui praticamente não haverá variação de registro tanto na forma como na maneira como as ações serão apresentadas.

Há nesse processo um contraste entre o discurso e a história narrada. Ainda que a composição apresente, em cada linha, acontecimentos espetaculares e inverossímeis, a linguagem permanece plana, em momento algum se contamina pelo teor do que é narrado. O livro é monocórdico, ou seja, a estrutura das frases obedece a ordenações que se repetem. É importante ressaltarmos que, ao contrário de Lugar público, não são frases ou parágrafos que se repetem, mas a estrutura dos períodos.

\footnotetext{
${ }^{143}$ Ver nota $n^{\circ} 135$ à página 75.
} 
Eu sobrevoava com o meu helicóptero os caminhões despejando areia no limite do imenso mar de gelatina verde. ${ }^{144}$

Eu disse que deveria ser um gesto mais enérgico e dramático, correspondente ao de patriarca do povo judeu. ${ }^{145}$

O jaguar veloz saltou com um estrondo para fora da murada e eu vi o mar sob as rodas. ${ }^{146}$

Eu desci de elevador e saí do gigantesco Cristo de concreto, atravessei a rua, e resolvi me esconder em casa. ${ }^{147}$

Eu suava muito e a força da gravidade tinha aumentado e me puxava para baixo e eu era obrigado a dar passos lentos para não cair. ${ }^{148}$

O alto-falante girava na escotilha do tanque bojudo e escuro e anunciava que nós deveríamos nos entregar. ${ }^{149}$

Eu mergulhei veloz no espaço perseguindo o piloto que caía de paraquedas aberto, furei o paraquedas e subi novamente e vi o piloto despencar no espaço. $\mathrm{O}$ jato desintegrou-se de encontro às águas do mar. ${ }^{150}$

Os bilhões de espermatozoides formaram um redemoinho negro sobre o lago artificial da feira, e giravam zumbindo a uma velocidade supersônica. ${ }^{151}$

${ }^{144}$ PAULA, José Agrippino de. PanAmérica. Rio de Janeiro: Tridente, 1967, p. 9.

${ }^{145}$ Idem, ibidem, p. 11.

${ }^{146}$ Idem, ibidem, p. 35.

${ }^{147}$ Idem, ibidem, p. 123.

${ }^{148}$ Idem, ibidem.

${ }^{149}$ Idem, ibidem, p. 147.

${ }^{150}$ Idem, ibidem, p. 176.

${ }^{151}$ Idem, ibidem, p. 186. 
A Estátua da Liberdade soltou um grito e lançou a tocha de concreto na multidão que corria em pânico. ${ }^{152}$

Eu retirei as vísceras e limpei o rosto na manga do paletó e as vísceras permaneceram flutuando ao meu lado. ${ }^{153}$

Apesar da similaridade não há, como podemos ver, monotonia. Ela é impossível diante do conteúdo, do material extraordinário que está sendo narrado. O "Eu" narrará suas ações em um fluxo hiperbólico de acontecimentos que se assemelham à lógica dos sonhos. Evelina Hoisel justificou a linguagem de Agrippino no romance:

Em PanAmérica, a constante repetição de palavras e conexões procura evocar o ritmo de uma máquina em funcionamento construindo assim a máquina da escrita ou a escrita como máquina. $\mathrm{O}$ alto grau de redundância introduzido no texto é, contudo, gerador de ambiguidade, porque esta repetição no plano linguístico é compensada por uma imprevisão no que se refere à lógica discursiva, a qual não obedece a um desenvolvimento linear dos fatos narrados. A lógica do discurso literário passa a ser a lógica do sonho. A linguagem confunde o leitor porque superpõe constantemente imagens oníricas e imagens reais, desconcentrando-o de qualquer referencialidade. Nesse sentido, atestamos também em PanAmérica um esvaziamento da representabilidade, porque as imagens muitas vezes não evocam nenhuma outra realidade, além delas mesmas. ${ }^{154}$

O afastamento da centralidade através da linguagem é precisamente o que garante ao relato sua característica mítica delirante, hiperbólica. Foi esse o "supercaos” apontado por Hoisel:

\footnotetext{
152 Idem, ibidem, p. 246.

${ }^{153}$ Idem, ibidem, p. 251.

${ }^{154}$ HOISEL, Evelina. Supercaos: os estilhaços da cultura em PanAmérica e Nações Unidas. Rio de Janeiro: Civilização Brasileira; Salvador: Fundação Cultural do Estado da Bahia, 1980, p. 127.
} 
Em PanAmérica e em As Nações Unidas, o supercaos está estritamente associado ao procedimento hiperbólico através do qual os textos de Agrippino de Paula se constroem. Através do supercaos se dramatiza o caos dos acontecimentos históricos e ele se torna a lente capaz de dimensionar a natureza confusa, desordenada e acidental da civilização tecnológica. ${ }^{155}$

O procedimento, efetuado no discurso, é garantido pelo trabalho com a linguagem. A estratégia de ordenação direta e a repetição das estruturas e de termos e procedimentos similares se assemelha a um processo industrial de composição, que ajuda a estabelecer e reforça o universo mítico moderno e a presença dos objetos da sociedade de massa no romance. $\mathrm{O}$ tom da narrativa, portanto, é adequado às façanhas do narrador. A rapidez do registro das ações busca representar a velocidade do mundo em que a narrativa está inserida. O método repetitivo confere unidade e força expressiva à obra, para a qual colaboram as descrições de cenas inusitadas com uma linguagem sem surpresas, o que nos faz pensar em Franz Kafka.

Em PanAmérica, chama a atenção o fato de o autor adotar uma linguagem objetiva para descrever o fantástico. Vimos, em Lugar público, como a relação do narradorprotagonista com o pai remete à figura do Pai em Kafka, sobretudo no conto "O veredito". Essa aproximação também é possível em relação àquelas passagens em que a realidade é deformada. Em PanAmérica, o procedimento de deformação da realidade é homogêneo. Diríamos que o livro propõe, na verdade a formação de uma realidade deformada.

Especialista no universo kafkiano, o crítico alemão Günter Anders, exemplificou o método de Kafka observando, a partir do conto "Na colônia penal", que o autor apresenta um objeto absurdo, o "Odvadek", de uma maneira pouco absurda.

[...] O objeto lembra-nos todos os tipos de objetos e máquinas com os quais o homem moderno tem que lidar diariamente, embora o trabalho delas não pareça ter nada a ver diretamente com as necessidades humanas. Milhares de

155 Idem, ibidem, p. 113. 
vezes o homem de nossos dias esbarra em aparelhos cuja condição lhe é desconhecida e com os quais só pode manter relações "alienantes", uma vez que a vinculação deles ao sistema de necessidades dos homens é infinitamente mediada: pois “estranhamento" não é um truque do filósofo ou do escritor Kafka, mas um fenômeno do mundo moderno - só que o estranhamento, na vida cotidiana, é encoberto pelo hábito oco. Kafka revela, através da sua técnica de estranhamento, o estranhamento encoberto da vida cotidiana - e dessa maneira é outra vez realista. Sua "deslocação" fixa. ${ }^{156}$

Resguardadas as particularidades, não é muito diferente o estranhamento causado em PanAmérica. O que muda é que, em Agrippino, essa infinita mediação será proporcionada pela presença quase massacrante daqueles seres mitológicos da sociedade de massa. Em Kafka, e esta é a diferença fundamental, a vida cotidiana é encoberta pelo hábito oco, mas ela ainda se realiza de um modo realista em um mundo que mantém referencialidades quebradas por um ou por alguns elementos da narrativa. Pensemos em "A metamorfose" ou em "Um relato para uma academia", por exemplo. São obras que causam estranhamento justamente porque, a despeito do fantástico, se situam precisamente num universo verossímil e trivial.

Já em PanAmérica o cotidiano está completamente fora do mundo realista talvez justamente pela alienação proporcionada pela presença massacrante e alienante dos aparatos e dos discursos da sociedade tecnológica. As referencialidades, como disse Evelina Hoisel, se perderam e o estranhamento será moeda corrente na narrativa. Ao mesmo tempo em que tudo é espantoso, nada parece espantar justamente pelo trabalho da linguagem e pela onipresença dos acontecimentos fantásticos.

Se em Kafka essa falta de espanto se dá pela cobertura do hábito oco, em PanAmérica a superconsciência do narrador em relação ao universo em que está inserido não causa espanto. Ele não está totalmente alienado como o homem kafkiano. Através de suas ações, o "Eu" de PanAmérica, ao mesmo tempo em que aceita a realidade do mundo mítico em que está inserido, procura a todo momento tomar parte, ser agente. $\mathrm{O}$ "Eu" do romance parece

\footnotetext{
${ }^{156}$ ANDERS, Günter. Kafka: pró e contra. Tradução de Modesto Carone. São Paulo: Perspectiva, 1993, p. 17
} e 18 . 
estar além daquilo que Anatol Rosenfed chamou de "poder metafísico insondável" que esmaga o homem kafkiano. ${ }^{157}$

\section{Romance mitológico}

Vimos em Lugar público como alguns dos relatos apresentam a realidade deformada. Em diversos momentos nesse romance o autor inicia as histórias com um aparente realismo que, aos poucos, vai rachando, contaminado por descrições e elementos fantásticos. Em PanAmérica, esse método será consolidado. A cena de abertura do livro será determinante para que isso aconteça, já que situa o narrador em meio a um universo extraordinário que logo descobrimos se tratar de um estúdio de cinema, ou seja, um espaço onde o fantástico é possível e verossímil.

Dissemos no capítulo anterior como a transmutação mítica da realidade, apenas uma tentativa para o narrador de Lugar público, estaria no centro de PanAmérica. Nesse romance, Agrippino explora de modo muito particular o caminho aberto na literatura moderna pela vanguarda do início do século XX.

Em Ulysses, obra fundamental para a literatura moderna, James Joyce recria o mito do Ulisses originário da Odisseia, de Homero, para falar da epopeia de um homem contemporâneo comum, vivendo em Dublin no início do século passado.

Leyla Perrone-Moisés conta como o poeta e crítico T. S. Eliot, um dos primeiros a reconhecer o valor literário da obra, observou que Ulysses fora escrito em um contexto de esgotamento do modelo romanesco realista praticado até meados do século XIX.

[...] Eliot considera que o romance, como gênero, está liquidado desde Flaubert e James; que Joyce sentiu a obsolescência do gênero e partiu para um método rico de possibilidades futuras: o uso do mito antigo, em paralelo

${ }^{157}$ ROSENFELD, Anatol. "Reflexões sobre o romance moderno". In: Texto/Contexto I. $5^{\text {a }}$ edição. São Paulo: Perspectiva, 1996, p. 94-95. 
com a experiência presente, com recurso à psicologia e à etnologia modernas.

Joyce parece estar na origem do uso do mito como método para o romance contemporâneo. É dentro dessa riqueza de possibilidades inaugurada por James Joyce que PanAmérica será escrito. No livro de Agrippino, como no de Joyce, "em vez do método narrativo, podemos usar agora o método mítico", de acordo com as palavras de Eliot. ${ }^{159}$

$\mathrm{Na}$ sequência de acontecimentos que se sucedem na narrativa, a recorrência ao mito vai prevalecer sobre os fatos narrados. Ao contrário, porém, do livro de Joyce, Agrippino vai utilizar esse método não em recorrência a mitos antigos, mas sim para se apropriar e criar um universo próprio com os mitos contemporâneos. Essa apropriação, acreditamos, equivale ao “método mítico" apontado por Eliot.

A recorrência a mitos e estruturas arquetípicas antigas é, portanto, um procedimento comum na ficção do século XX. José Luiz Passos, que estudou as relações entre Macunaíma, a rapsódia de Mário de Andrade, e o Ulysses, na tentativa de apontar o que era comum e o que era particular aos dois romances, recorre à noção de deslocamento em Northop Frye:

Para o crítico canadense a ideia de deslocamento está associada à de mito. Esta última pode ser tomada como sinônimo de um procedimento narrativo que não sujeita a organização de seus elementos a critérios miméticos estritamente verossimilhantes. Mas que, ao invés disso, afirma-se como a estilização de elaborações ficcionais abstratas ao sabor das vontades do narrador. ${ }^{160}$

PanAmérica não está sujeito a esses critérios. A subversão da noção de verossimilhança e a submissão do material narrativo unicamente à vontade do narrador estão no centro do romance de Agrippino. De acordo com Passos,

\footnotetext{
${ }^{158}$ PERRONE-MOISÉS, Leyla. Altas literaturas: escolha e valor na obra crítica de escritores modernos. São Paulo, Companhia das Letras, 2009, p. 132-133.

${ }^{159} \mathrm{Idem}$, ibidem, p. 133.

${ }^{160}$ PASSOS, José Luiz. "Prefiguração musical em Ulisses e Macunaíma". In: Ruínas de linhas puras: quatro ensaios em torno a Macunaíma. São Paulo: Annablume, 1998, p. 74.
} 
Mito "é a imitação de ações próximas, ou sujeitas aos limites concebíveis do desejo" (FRYE, 1990: 136); ele cria um mundo sobrenatural que suspende as leis do mundo real e submete este mundo aos poderes dos personagens. [...] O desenvolvimento da literatura, em Frye, se dá através das diferentes soluções para a tensão estabelecida entre as duas tendências fundamentais que orientam o fazer literário: a tendência mimética, que enfatiza a verossimilitude da representação; e a mitológica, que contrariamente à primeira, não deriva diretamente de analogias exteriores ao próprio mundo da literatura. ${ }^{161}$

A tendência mitológica equivale ao "método mítico" apontado por T. S. Eliot. Se pensarmos em Ulysses e Macunaíma, veremos que PanAmérica recorre à apropriação de um material de origem. Ambos os modernistas, Joyce na Europa e Mário de Andrade no Brasil, têm na origem de seus romances materiais da tradição, a escrita, no caso de Joyce, e a oral, no caso de Mário de Andrade ao retrabalhar os mitos dos índios da Amazônia.

Macunaíma (1929) e Ulisses (1922), em medidas amplas, apresentam-se como analogias de um mesmo procedimento: ambos encenam uma operação de deslocamento. Existe um primeiro texto, o texto-origem, que é chamado a testemunhar sempre que o autor precisa justificar o desenvolvimento de seu enredo. E existe um segundo texto, os dois romances modernistas, resultantes do itinerário de deslocamento das matrizes míticas: as lendas indígenas do Amazonas e a Odisseia de Homero. Assim, para os dois textos em questão, deslocamento é sinônimo de um processo filológico análogo de derivação e organização de certas estruturas e materiais narrativos preexistentes em direção ao contexto de uma segunda escritura. ${ }^{162}$

\footnotetext{
${ }^{161}$ Idem, ibidem, p. 74-75.

162 PASSOS, José Luiz. "Prefiguração musical em Ulisses e Macunaíma". In: Ruínas de linhas puras: quatro ensaios em torno a Macunaíma. São Paulo: Annablume, 1998, p. 72.
} 
Ao contrário desses modernistas, que partiram da tradição literária, Agrippino tomará como material de origem os conteúdos e algumas técnicas cinematográficas. PanAmérica vai, assim, se apropriar de um material de origem extraliterário: os já mencionados cinema e as personalidades históricas divulgadas pela indústria cultural. $\mathrm{O}$ autor identificou nessa expressão industrial e artística a mitologia necessária para falar de seu tempo de modo alegórico.

A presença do cinema será constante na obra de Agrippino, não apenas a literária. Em 1969, o Rito do amor selvagem, peça que estava em cartaz naquele ano e que montava algumas cenas de As Nações Unidas, foi objeto de uma crítica de Anatol Rosenfeld.

José Agrippino de Paula obteve repercussão com duas obras narrativas, Lugar público e Panamérica, ambas de teor vanguardeiro. Nestes livros se nota a tendência à colagem de pequenos quadros ou planos, frequentemente de acento onírico e sempre de grande insistência nos aspectos visuais. O princípio da montagem e a preponderância da dimensão visual pareceriam predestiná-lo para o cinema, como ocorre no caso de RobbeGrillet com quem mostra certas afinidades. O cinema e seus "mitos" tornouse de fato temático tanto em Rito do Amor Selvagem como em Panamérica, obra em que as técnicas de panoramizar o travelling foram aplicadas à literatura. ${ }^{163}$

Se em Lugar público o cinema aparece tematicamente como espaço frequentado pelo narrador e seus amigos, em PanAmérica ele aparecerá como técnica, como uma forma de entretenimento industrial, ou seja, como fábrica de mitos. O livro tratará da imposição dos mitos produzidos em Hollywood sobre uma sociedade subdesenvolvida. Partindo do universo mitológico, o autor cria uma narrativa em que o narrador-protagonista vive aventuras perpassadas por temas contemporâneos como o imperialismo, a guerrilha e a precariedade da condição subdesenvolvida.

${ }^{163}$ ROSENFELD, Anatol. “O rito do amor selvagem”. In: Prismas de teatro. São Paulo: Perspectiva: Editora da Universidade de São Paulo; Campinas: Editora da Universidade Estadual de Campinas, 1993, p. 231 (grifos do autor). 
Mais do que isso, em PanAmérica, o cinema terá espaço central, não apenas como tema ou fornecedor de mitos e de elementos para a composição da obra, mas como princípio de composição e organização da própria escrita. As descrições das ações que dominam a narrativa, o sucedâneo de acontecimentos que se justapõem uns aos outros assemelham-se a uma montagem cinematográfica. $\mathrm{O}$ fato de essas ações serem predominantemente visuais também demonstra a presença da técnica cinematográfica.

A partir da obra de Alain Robbe-Grillet, Roland Barthes disse que o cinema operou uma revolução nos "reflexos da visão". ${ }^{164}$ A presença do cinema na sociedade contemporânea, sobretudo naquele século, vai transformar os modos de ver. Na arte da narrativa literária, a expressão terá impacto muito grande no Novo Romance Francês. Reflexo disso é que o próprio Robbe-Grillet, como faria Agrippino, se aventurou como diretor de cinema.

Não é coincidência que inúmeros artistas surgidos entre as décadas de 1950 e 1960 tenham experimentado ao menos uma vez a direção de filmes. Além de Agrippino e RobbeGrillet, podemos citar, por exemplo, Jorge Mautner e Caetano Veloso no Brasil e Bob Dylan nos Estados Unidos. Há nisso uma importante diferença em relação àqueles escritores que, como William Faulkner e Gore Vidal, principalmente em Hollywood, exerceram a função de roteiristas. Isso ocorre até hoje, mas, nesses casos, os escritores prestam-se a fornecer ao cinema um argumento ou um roteiro semelhante a uma peça com marcações de cenas, diálogos e intenções dos atores. Trata-se, nesses casos, de uma peça literária no mais das vezes bastante convencional feita para ser filmada. Não são poucos os estudiosos que associam principalmente o cinema norte-americano à literatura clássica em um processo que remete ao teatro inglês que, por sua vez, tem na origem o teatro clássico grego cujas características foram apontadas ainda por Aristóteles na Poética. Para exemplificar o que estamos dizendo basta pensarmos na obra literária inovadora de Faulkner e nos roteiros que ele escreveu sob encomenda para Hollywood adaptando autores como Ernest Hemingway e Raymond Chandler como forma de ganha-pão.

No caso de Agrippino o cinema exerceu outro tipo de atração. A expressão não interessava ao autor como veículo para transpor ou adaptar histórias "escritas". O que ele fez

${ }^{164}$ BARTHES, Roland. "Literatura objetiva". In: Crítica e verdade. Tradução de Leyla Perrone-Moisés. São Paulo, Perspectiva, 2013a, p. 87. 
em seus filmes foi contar histórias com a câmera, a encenação e a montagem. Em Hitler, por exemplo, sobressai a técnica cinematográfica, não o "enredo". A técnica sobressai sobre o enredo. Voltando a Holywood, é fácil, a partir de um filme acabado, contar suas histórias de forma escrita para que sejam publicadas em livro. Nos países desenvolvidos isso não é de todo incomum. Já em relação aos demais artistas citados, a tarefa seria mais difícil ou pelo menos o livro resultante do filme não seria uma obra tão "palatável”.

A utilização do cinema por artistas de outras áreas foi possível porque, também na França, no fim dos anos 1950, surgiu um grupo de novos realizadores dispostos a subverter a narrativa cinematográfica. Muitos desses cineastas como François Truffaut e Jean-Luc Godard, entre outros, são contemporâneos de autores do Novo Romance. Os diretores desse movimento, chamado Nouvelle Vague, procuravam valorizar o trabalho de diretores até então desprezados como, por exemplo, Orson Welles e Alfred Hitchcock. Além disso, concebiam um cinema chamado "de autor" e realizavam experiências com o posicionamento da câmera e com a montagem do som e da imagem visando justamente romper com a narrativa linear baseada no teatro clássico, que tentava ocultar dos espectadores justamente a técnica que permitia que o cinema existisse. Frederic Raphael lembrou que, em relação aos filmes, "Jean-Luc Godard satirizaria o velho princípio aristotélico quando disse que com certeza deveria haver começo, meio e fim, mas não necessariamente nessa ordem". ${ }^{165}$ Os modelos desses cineastas vinham da época do Modernismo, das experimentações de vanguarda realizadas por nomes como René Clair e Luís Buñuel, por exemplo. Muito mais do que o Novo Romance, as técnicas propostas pelos diretores franceses tiveram grande penetração no Brasil, influenciando, juntamente com o Neo Realismo cinematográfico italiano, o movimento do Cinema Novo.

Assim, Alain Robbe-Grillet foi enfático ao dizer que o cinema interessava aos novos romancistas como técnica de pesquisa mais do que como meio de expressão:

O atractivo evidente que a criação cinematográfica exerce sobre muitos dos novos romancistas tem de ser procurado em qualquer outra parte. Não é a objetividade da câmera que os apaixona, mas as suas possibilidades

\footnotetext{
${ }^{165}$ RAPHAEL, Frederic. Kubrick de olhos bem abertos. São Paulo: Geração Editorial, 1999, p. 113.
} 
no domínio do subjectivo, do imaginário. Não concebem o cinema como um meio de expressão, mas de pesquisa, e o que retém mais a sua atenção é muito naturalmente o que mais escapava aos poderes da literatura: isto é, não tanto a imagem como a banda sonora - o som das vozes, os ruídos, as ambiências, as músicas -, e sobretudo a possibilidade de actuar sobre dois sentidos ao mesmo tempo, a vista e o ouvido; em suma, na imagem como no som, a possibilidade de apresentar com toda a aparência da objectividade menos contextável, o que não é, afinal, senão sonho ou recordação, numa palavra o que é só imaginação. ${ }^{166}$

As descrições de PanAmérica são apresentadas de modo objetivo, mas, paradoxalmente, como que captadas por uma câmera que adotasse a visão subjetiva do "Eu" que narra. Estamos nos referindo à técnica da câmera subjetiva que, em um filme, representa o ponto de vista de determinada personagem, e não à subjetividade do narrador.

A imaginação de Agrippino vai se apropriar do cinema, a arte de massa por excelência no período, que tornava o mito mais apropriado já que a narrativa cinematográfica era capaz de penetrar e impregnar o imaginário do homem moderno de modo mais firme e permanente. A televisão, na década de 1960, apenas começava a ascensão que a tornaria o veículo predominante a partir da década seguinte.

A escolha dos personagens principais de PanAmérica, sobretudo Marilyn Monroe, visa ao estabelecimento de uma identificação imediata por parte do leitor. Isso ocorre porque, na sociedade massificada, o mito cinematográfico dispensa apresentações, ele é demasiado propalado e conhecido. Em algumas cenas do livro, as personagens "reais" mantêm traços, características ou imagens correspondentes às personagens ficcionais que interpretaram e as consagraram no cinema como, por exemplo, o papel de loira fatal que coube a Monroe em Hollywood ou o papel de cowboy machão desempenhado por John Wayne. Do mesmo modo, a filmagem que será mostrada na cena inicial da narrativa é a abertura do Mar Vermelho, cuja filmagem por Cecil B. DeMille em Os dez mandamentos ficou marcada nas gerações que cresceram no pós-guerra. ${ }^{167}$

\footnotetext{
${ }^{166}$ ROBBE-GRILLET, Alain. “Tempo e descrição na narrativa de hoje”. In: Por um novo romance. Tradução de Cristóvão Santos. Lisboa, Publicações Europa América, 1965, p. 161-162.

${ }^{167}$ Os dez mandamentos foi filmado e refilmado por Cecil B. DeMille em Hollywood em 1923 e 1956.
} 
Nogueira Moutinho observa que, nessa na cena, o narrador-protagonista filma "uma superprodução bíblica hollywoodiana, na qual os milagres da técnica cinematográfica substituem os fatos miraculosos relatados na Bíblia". ${ }^{168}$ Agrippino busca, portanto, a exposição da técnica, os meios tecnológicos que tornam possível a realização das imagens fantásticas.

O autor parte de uma cena "real" para situar o leitor e convidá-lo a entrar na história. Essa opção por iniciar o livro com uma cena aparentemente realista ditará a própria realidade ficcional da obra. Daí o estúdio de cinema, ainda que, mesmo em se tratando de um estúdio, as proporções sejam muito maiores do que em sua correspondência com a realidade, ou seja, elas também são deformadas. A partir daí os mitos ganham autonomia.

$\mathrm{Na}$ cena de abertura do romance, o narrador-protagonista é o diretor de cinema da superprodução hollywoodiana "A Bíblia". Ele descreve os aspectos de uma filmagem cujo aparato técnico é, em si, fantástico, e suas relações com atores como Cary Grant e Marilyn Monroe durante a feitura da cena da fuga dos judeus do Egito. Hollywood, a maior indústria de mitos contemporâneos, é apresentada em todas as suas dimensões industriais fantásticas. Esse lugar em que tudo é aparentemente possível vai ditar as características maravilhosas do livro. É como se, a partir da fábrica de mitos cinematográfica, criadora de realidades fantásticas, o autor situasse sua criação nessa esfera suprarreal e o leitor naquele universo estranho e até incômodo.

A escolha da filmagem da Bíblia não é à toa, uma vez que, ao lado da mitologia grega, o livro sagrado de judeus e cristãos é a maior fonte de mitos do imaginário ocidental. O autor demonstra como o cinema (e mais ainda Hollywood) é capaz não só de criar mitologias contemporâneas, mas também de reinventar a própria mitologia clássica.

Esse material de origem do livro, a realidade histórica, sobretudo da indústria cultural, principalmente por meio do cinema, extrapola as fronteiras do mundo físico para adentrar na esfera mítica, que vai constituir o universo próprio da narrativa.

Sendo um romance de tendência mitológica, em PanAmérica o tempo é anulado. Os acontecimentos narrados se situam numa esfera mítica que permite ao narrador-protagonista

${ }^{168}$ MOUTINHO, José Geraldo Nogueira. “Panamérica”. In: A fonte e a forma. Rio de Janeiro, Imago, 1977, p. 53. 
saltar de um evento para outro sem qualquer marcador temporal em uma espécie de presente eterno. O livro, desse modo, estaria completamente fora da História, mas isso não quer dizer que não mantenha, como toda obra, relação com a História. Essa relação existe e é fundamental para a compreensão da obra.

Roland Barthes comentou o processo de transição entre a História e o mito e apontou o que acontece nessa passagem:

[..] Passando da história à natureza, o mito faz uma economia: abole a complexidade dos atos humanos, confere-lhes a simplicidade das essências, suprime toda e qualquer dialética, qualquer elevação para lá do visível imediato, organiza um mundo sem contradições, porque sem profundeza, um mundo plano que se ostenta em sua evidência, e cria uma afortunada clareza: as coisas, sozinhas, parecem significar por elas próprias. ${ }^{169}$

A abolição da complexidade na narrativa nos ajuda a entender a aparente superficialidade e a superexposição de PanAmérica, seja nas descrições, seja na caracterização das personagens, seja na falta sequência de acontecimentos sem sustentação no mundo físico. O material mitológico apropriado pelo romance parece natural e claro, ainda que tenha por trás de si uma complexidade de referências.

É nesse sentido de supressão da dialética e do mundo organizado sem contradições que o livro pode ser entendido como uma obra de imaginação pura, como uma obra literária autônoma e experimental que constitui um universo fechado e autônomo.

Essa, no entanto, não é a única leitura possível do romance. A presença da História na narrativa nos obriga a pensar o livro como um produto de seu tempo. Com tudo o que tem de delirante e fantástico, PanAmérica pode ser lido como um romance alegórico das convulsões da década de 1960 no Brasil e na América Latina.

Ismail Xavier, que estudou as alegorias do subdesenvolvimento no cinema brasileiro daquela década, diz que "é na relação com o mito, enquanto forma particular de interpretá-

${ }^{169}$ BARTHES, Roland. Mitologias. Tradução de Rita Buongermino, Pedro de Souza e Rejane Janowitzer. $7^{\text {a }}$ edição. Rio de Janeiro, Difel, 2013b, p. 235. 
lo, que a alegoria encontra, historicamente, sua origem". ${ }^{170}$ De acordo com o crítico, a alegoria é justamente o recurso que permite ao mito reaproximar-se, mesmo que em outra leitura, da relação original que o estabeleceu.

[...] A referência que o mito traz a fatos acontecidos no espaço e no tempo, sua narração, fica transformada em dispositivo imaginativo que, de modo deslocado, expõe conceitos. A leitura alegórica é a expressão da crise da transparência do mito que perde sua vigência integral. Ao mesmo tempo é, também, dentro da própria crise, um elemento de resgate, de recuperação do sentido, uma vez assumida a não verdade da letra. A alegoria é uma solução de compromisso que ficcionaliza (desqualifica) o texto do mito, mas faz emergir sua verdade escondida (que está em outro lugar). Em todo o percurso, a mesma lógica: trata-se de desocultar o que foi supostamente ocultado (estratégia privilegiada de afirmação de novas verdades a partir das mesmas aparências). ${ }^{171}$

É por meio da alegoria que PanAmérica vai fazer referência ao contexto histórico, com todos os seus símbolos culturais e políticos, em que está inserido. Há, nesse processo, a perda da visão integral do mito como elemento autossuficiente. A recorrência ao cinema, aos líderes políticos, à guerrilha, todas trabalhadas dentro da elaboração mitológica, são, portanto, alegorias da condição subdesenvolvida que permite a produção da própria narrativa.

Mesmo que o tempo histórico não seja mencionado na narrativa, que ele não seja contextualizado, já que os acontecimentos inseridos na esfera mítica não têm qualquer referência temporal, não é difícil entendermos o romance como um produto de um mundo polarizado e altamente tecnológico. Mais especificamente ainda como produto de uma realidade subdesenvolvida. Assim, não seria irônico, portanto, chamarmos PanAmérica de um romance subdesenvolvido.

\footnotetext{
${ }^{170}$ XAVIER, Ismail. “A alegoria segundo a tradição: retrospecto. In: Alegorias do subdesenvolvimento, cinema novo, tropicalismo, cinema marginal. São Paulo: Cosac Naify, 2012, p. 462-463.

${ }^{171}$ Idem, ibidem.
} 
A apropriação dos elementos da cultura de massa e da temática da guerrilha situam o livro entre alguns dos principais acontecimentos daqueles anos. Mas não é apenas o Brasil ou a realidade brasileira que serão representados, e sim uma realidade latino-americana na qual o Brasil está inserido, a porção do continente que lutava, através da guerrilha, contra o poderio industrial, militar e cultural da maior nação desenvolvida do continente, os Estados Unidos.

A luta é travada pelo narrador-protagonista, que se embate contra os símbolos da cultura de massa norte-americana. Nesse contexto, a apropriação dos mitos efetuada por Agrippino também não deixa de ser irônica. A própria linha central da narrativa, a do cineasta subdesenvolvido e seus relacionamentos com estrelas de cinema, tem muito de ironia. Longe de elevar a realidade precária, a parte latina do continente, à altura do desenvolvimento industrial da porção norte da América, o autor expõe os mitos, elevados, em suas contradições, rebaixando-os a uma condição também precária.

Seguindo a argumentação de Ismail Xavier, podemos concluir que a verdade escondida de PanAmérica é a realidade do continente, tão bem retratada no próprio título da obra.

No capítulo de seu estudo que trata das relações entre a História e ficção, Evelina Hoisel diz que Agrippino parte de uma "concepção da História como ficção", observando que, na representação do acontecimento histórico efetuada pelos donos do poder, "há sempre uma ocultação, uma deformação", já eles constroem, ideologicamente, uma representação de si mesmos.

A apropriação de heróis políticos, além dos astros de cinema já mencionados, confere maior verossimilhança aos textos de Agrippino de Paula. Desde que essas personagens penetram no espaço do livro, temos um discurso ficcional contaminado por um discurso historiográfico. Como aí estão em jogo duas figurações - as personagens reais e as da ficção -, o texto literário perde, inicialmente, sua carga de ficcionalidade, tornando-se historiográfico. Nesse sentido a $P A$ e a $N U$ não aplicamos apenas a terminologia de Walter Benjamin usou em relação à literatura: uma "historiografia inconsciente". Agrippino pretende constituir uma ficção historiográfica, porque já toma a própria história como ficção. Nesse sentido, 
em vez de declararmos que ele procede a uma desficcionalização do texto literário, melhor definimos seu procedimento nomeando-o re-ficcionalização da história. ${ }^{172}$

É justamente essa leitura da História como ficção que vai permitir a apropriação indiscriminada de seus elementos. Nesse sentido, os capítulos iniciais, aqueles da filmagem "A Bíblia", são simbólicos já que a própria Bíblia, com sua carga de mitos, pode ser interpretada também como uma "re-ficcionalização da História". ${ }^{173} \mathrm{O}$ mesmo se aplica ao cinema que, além do elemento mitológico, apropria-se do fato histórico. E aqui voltamos a Roland Barthes. O crítico observa que o mito tem, na origem, um fato histórico indispensável que, uma vez apropriado, abandona justamente os elementos temporais que lhe serviram como fonte de inspiração:

O que o mundo fornece ao mito é um real histórico, definido, por mais longe que se recue no tempo, pela maneira como os homens o produziram ou utilizaram; e o que o mito restitui é uma imagem natural desse real. E, do mesmo modo que a ideologia burguesa se define pela deserção do nome do burguês, o mito é constituído pela eliminação da qualidade histórica das coisas; nele, as coisas perdem a lembrança de sua produção. O mundo penetra na linguagem como uma relação dialética de atividades e atos humanos; sai do mito como um quadro harmonioso de essências. Essa prestidigitação inverteu o real, esvaziou-o de história e encheu-o de natureza, retirou às coisas o seu sentido humano, de modo a fazê-la significar uma insignificância humana. A função do mito é evacuar o real: literalmente, o mito é um escoamento incessante, uma hemorragia ou, caso se prefira, uma evaporação; em suma, uma ausência perceptível. ${ }^{174}$

\footnotetext{
${ }^{172}$ HOISEL, Evelina. Supercaos: os estilhaços da cultura em PanAmérica e Nações Unidas. Rio de Janeiro: Civilização Brasileira; Salvador: Fundação Cultural do Estado da Bahia, 1980, p. 51-53.

${ }^{173}$ Idem, ibidem.

${ }^{174}$ BARTHES, Roland. Mitologias. Tradução de Rita Buongermino, Pedro de Souza e Rejane Janowitzer. $7^{\text {a }}$ edição. Rio de Janeiro, Difel, 2013b, p. 234.
} 
Por esse escoamento incessante o livro restitui do "real" a imagem de uma natureza em convulsão. PanAmérica, portanto, não deixa de ser uma alegoria dos anos 1960 na América Latina ao expor os mecanismos de infiltração e de imposição, sobretudo culturais, do imperialismo dos Estados Unidos, país desenvolvido e principal potência do chamado "primeiro mundo" no período da Guerra Fria, sobre países em desenvolvimento, os subdesenvolvidos do "terceiro mundo".

Em linhas gerais, PanAmérica pode ser filiado à cultura pop ou à arte pop. O movimento, que eclodiu nas artes plásticas a partir do final da década de 1950, como observa Arthur C. Danto, não chegou a se firmar como uma escola na literatura ou mesmo em outros meios de expressão artísticos.

A expressão "arte pop” foi usada pela primeira vez em 1958 pelo crítico britânico Lawrence Alloway para designar a cultura de massa dos Estados Unidos, especialmente os filmes de Hollywood. O argumento de Alloway era que esses filmes, assim como os romances de ficção científica, eram obras sérias e mereciam ser estudadas como os filmes de arte, a grande literatura e os produtos da cultura de elite em geral. Mas por algum deslize, o termo passou a designar exclusivamente pinturas - esculturas - de objetos e imagens ligados à cultura comercial, ou a objetos fácil e amplamente reconhecíveis, cujo uso ou significado não precisavam ser explicados. [...] $]^{175}$

O livro de Agrippino explora incessantemente os elementos que compõem a cultura de massa do período a partir do principal centro irradiador dessa cultura, os Estados Unidos, e de sua mais bem acabada forma de expressão: o cinema. Evelina Hoisel afirma que o livro anunciava,

[...] no contexto cultural brasileiro, de maneira precursora e contundente, o processo de democratização do literário, rompendo com as dicotomias

${ }^{175}$ DANTO, Arthur C. Andy Warhol: Arthur C. Danto. Tradução de Vera Pereira. São Paulo: Cosac Naify, 2012, p. 49-50. 
estabelecidas entre alta/baixa literatura, literatura erudita/literatura popular, literatura/paraliteratura, estético/não estético. ${ }^{176}$

O raciocínio é desenvolvido de modo a mostrar que, ao apropriar-se de elementos da indústria cultural, da cultura de massa ou cultura pop, o autor transforma o próprio livro em produto dessa cultura, mas com viés crítico. A apropriação desses elementos é configurada pela criação de um universo inverossímil e fantástico. Até mesmo o suposto realismo da filmagem em Hollywood ou o acampamento guerrilheiro na selva no livro é submetido a uma visão suprarreal ou onírica.

Absorver os estímulos da cultura de massa e responder a eles de um modo original e local foi uma das principais marcas do tropicalismo, programa estético que foi muito além de sua expressão mais conhecida, o território da composição popular. Basta pensarmos em artistas como Hélio Oiticica e no próprio Antonio Dias nas artes plásticas, além de Glauber Rocha no cinema. O movimento, que resgatou a antropofagia de Oswald de Andrade, tem muitas características em comum com o trabalho de Agrippino, principalmente na alegoria de PanAmérica. Além da apropriação dos elementos da cultura de massa, podemos pensar no texto fortemente imagético e na crítica à imposição da cultura estrangeira. De acordo com Celso Favaretto,

A mistura tropicalista notabilizou-se como uma forma sui generis de inserção histórica no processo de revisão cultural, que se desenvolvia desde o início dos anos 60. Os temas básicos dessa revisão consistiam na redescoberta do Brasil, volta às origens nacionais, internacionalização da cultura, dependência econômica, consumo e conscientização. Tais preocupações foram responsáveis pelo engajamento de grande parte dos intelectuais e artistas brasileiros na causa da construção de um Brasil novo, através de diversas formas de militância política [...]. ${ }^{177}$

\footnotetext{
${ }^{176}$ HOISEL, Evelina. "PanAmérica: uma cartografia dos processos de globalização nos anos de 1960". In: Recôncavos (Revista do Centro de Artes, Humanidades e Letras vol. 2 (I), 2008, p. 2.

${ }^{177}$ FAVARETTO, Celso Fernando. Tropicália, alegoria, alegria. $4^{\mathrm{a}}$ edição. Cotia, SP: Ateliê Editorial, 2007, p. 28.
} 
Sem mencionarmos sua forma peculiar de militância política, alguns dos elementos citados, como a internacionalização da cultura, a dependência econômica e o consumo são próprios de PanAmérica. Evelina Hoisel foi a primeira a comentar as características que aproximavam a obra de Agrippino da estética tropicalista. Seguindo a linha de pensamento de Roberto Schwarz, que, como vimos, definiu o movimento tropicalista como "uma variante brasileira e complexa do pop", ${ }^{178}$ ela apontou as escolhas estéticas e propôs uma interpretação crítica para a obra de Agrippino, associando-a uma estética pop.

O primeiro elemento de ligação entre pop e os discursos de Agrippino de Paula se encontra na escolha temática. Todas as características catalogadas por Simon Marchan sobre a temática pop podem ser encontradas nos textos de PA e NU. Ambos constroem-se a partir do repertório iconográfico manipulado pela indústria cultural. Nesse sentido, Agrippino de Paula já efetua a primeira dessacralização do texto literário, uma vez que se apropria de temas considerados pouco "nobres" pela arte "culta" e de elite. Mas o leitor atento pode perceber, já numa primeira leitura, que esses textos se organizam através de uma visão crítica desse material que utiliza. Se as estórias de sexo e violência se alternam no espaço textual, sem nenhuma postura crítica aparente, ou se sucedem no mesmo nível da arte de consumo, incitando a fantasia através dos elementos fantásticos que manipula, ele o faz a partir de uma atitude altamente irônica e gozativa. Talvez essas formas levem o leitor menos atento a considerá-las não críticas. Mas este tipo de confusão parece já ser intencional, faz parte da estética do caos proposta por Agrippino. Por trás do que é fornecido manifestamente, subjaz uma atitude crítica que se utiliza do mesmo material que pretende denunciar. ${ }^{179}$

Em PanAmérica, através da apropriação dos elementos da cultura de massa, Agrippino revela, em um contexto global e, talvez por isso mesmo, caótico, o choque causado

${ }^{178}$ SCHWARZ, Roberto. “Cultura e política, 1964-69”. In: O pai de família e outros ensaios. São Paulo, Companhia das letras, 2008, p. 84.

${ }^{179}$ HOISEL, Evelina. Supercaos: os estilhaços da cultura em PanAmérica e Nações Unidas. Rio de Janeiro: Civilização Brasileira; Salvador: Fundação Cultural do Estado da Bahia, 1980, p. 138-139. 
pela violenta imposição do poderio econômico e do consequente domínio cultural com a penetração de bens simbólicos dos países ricos sobre realidades periféricas, num sistema industrial de produção de cultura.

Por isso, o livro pode ser lido à luz da crítica ao processo de modernização que o Brasil atravessava desde o final da década de 1950. Ao mesmo tempo em que se entusiasma com as tecnologias e com as linguagens da cultura de massa, o romance critica a corrida pelo desenvolvimento, denunciando a condição subdesenvolvida, mas nunca, que fique claro, de um modo organizado ou racional.

\section{Obra de excesso}

Ainda que o erotismo proposto inicialmente tenha sido abandonado no título final, ele é um aspecto importante de PanAmérica menos em si do que por representar uma espécie de quebra na uniformidade do romance. Isso porque a "obsessão erótica"180 que marca o livro dá uma dimensão mais íntima e individual ao narrador e às personagens.

Aspectos do erotismo ficarão evidentes sobretudo nas relações do protagonista com a atriz Marilyn Monroe. Além da atriz, ele também viverá aventuras homoeróticas com soldados do Exército e manterá relações pedófilas com uma menina. É com a estrela norteamericana, chamada de "afrodite ianque" por Mário Schenberg, ${ }^{181}$ que o erotismo será explorado de modo mais direto. Como ícone de Hollywood, Marilyn é uma figura central do romance.

Antes mesmo de sua morte precoce em 1962, a atriz tinha se tornado um dos maiores mitos de Hollywood. Ela era, sem dúvida, o principal símbolo do erotismo fabricado pelo cinema norte-americano. Seu papel já tinha extrapolado as dimensões da indústria cinematográfica e a figura de Marilyn Monroe se tornado célebre também a partir de uma pintura seriada em 50 retratos feita pelo artista plástico norte-americano Andy Warhol, cujo nome se confunde com a própria arte pop.

180 SCHENBERG, Mario. “Apresentação”. In: PanAmérica. Rio de Janeiro, Tridente, 1967.

${ }^{181}$ Idem, ibidem. 
Em PanAmérica, como no cinema ou nas artes plásticas, a atriz será representada de diversas formas. Vejamos alguns casos:

[...] Depois eu parei diante do espelho e permaneci alguns instantes observado Marilyn Monroe, a atriz adolescente, se movimentando à frente do amplo espelho. Marilyn Monroe olhou para mim pelo espelho, sorriu e fez com os braços como se fosse halterofilista mostrando sua força. [...] ${ }^{182}$

[...] Nós dois voltamos para o pátio do estúdio, onde um grupo de extras jogava vôlei, e quando nós entramos no pátio eu vi Marilyn Monroe de biquíni, mas sem soutien, com os seios à mostra. Marilyn talvez pretendia ser irreverente com os produtores de Hollywood jogando vôlei com os seios de fora. $[\ldots]^{183}$

[...] O garoto se movimentava rapidamente sobre ela, se introduzia debaixo da pia, procurava as ferramentas que estavam sob o corpo de Marilyn Monroe e ela levantava um pouco as nádegas e o garoto introduzia a mão, olhava para mim rápido como se estivesse se justificando, ela olhava para mim ternamente como se dissesse que eu estava imaginando coisas e que o garoto estava somente consertando a pia. Marilyn Monroe levantou-se nua e mostrou no seu vestido vermelho as várias espécies de esperma. Eu olhei as marcas no vestido vermelho e cintilante e ela explicou para mim que de acordo com a consistência do líquido poderia se calcular a idade do homem que tinha produzido o esperma. Os velhos possuíam um esperma mais amarelo. [... $]^{184}$

Símbolo da sedução e da erotização do império americano, a atriz será desvirginada e conquistada pelo narrador em páginas que vão de um relacionamento mais terno e suave até o sexo visto de modo ritualístico.

\footnotetext{
${ }^{182}$ PAULA, José Agrippino de. PanAmérica. Rio de Janeiro: Tridente, 1967, p. 30.

${ }^{183}$ Idem, ibidem, p. 32-33.

${ }^{184}$ Idem, ibidem, p. 71.
} 
Eu e ela estávamos ali encostados na parede. Ela estava em silêncio e eu estava em silêncio. Eu sentia o corpo dela junto ao meu, os dois seios, o ventre, as pernas, e os seus braços me envolviam. Eu pensei que ela deveria sentir o calor que eu estava sentindo. Nós dois estávamos imóveis encostados à parede, eu não me recordo quanto tempo, mas nós estávamos abraçados e encostados ali há muito tempo. E não me recordava se eram horas, dias ou meses. Nós dois esquecemos naquele momento que nós dois pretendíamos a paz dentro da violência do mundo, e sem perceber a chegada da paz nós dois estávamos alojados dentro dela. Nós não saímos da parede e a paz nos encontrou subitamente, não enviou nenhum sinal, e nós não procuramos a paz. ${ }^{185}$ Ela tirou o vestido e eu disse que ela deveria ter... Eu e ela nus. Quando terminar o fim do mundo nós iremos para qualquer lugar. Nós estávamos bem um ao lado do outro. Quando Marilyn Monroe levantou-se eu vi o seu corpo nu de baixo para cima $[\ldots]^{186}$

[...] Neste instante Marilyn Monroe permaneceu imóvel, mas colocou o pé sobre a minha barriga e apertou o pé na minha barriga. Depois ela se ajoelhou ao meu lado e sentou sobre os calcanhares com as coxas unidas. Eu segurei o meu membro rijo entre os dedos diante de Marilyn Monroe e ela abriu as suas pernas mostrando os pelos e o sexo. Eu me ajoelhei segurando o meu membro latejante e aproximei a cabeça vermelha do meu membro do sexo de Marilyn, e ela encolheu mais as pernas junto do corpo e abriu com os dedos as peles que formavam os lábios do seu sexo. Eu rasguei com a unha a tampa de papel que era a virgindade de Marilyn Monroe, tampa de papel estava pregada nos bordos do sexo de Marilyn onde não existiam pelos. [...] ${ }^{187}$

Ainda que em todo o livro a psicologia praticamente inexista, nesse capítulo específico, o quinto da narrativa, que tem como protagonistas apenas essas duas personagens, o "Eu” e Marilyn, a relação erótica abre espaço para o traço psicológico.

\footnotetext{
${ }^{185}$ Foi esse o trecho foi musicado por Gilberto Gil e Caetano em "Eu e ela estávamos ali encostados na parede".

${ }^{186}$ Idem, ibidem, p. 57.

${ }^{187}$ Idem, ibidem, p. $57-58$
} 
[...] Eu subi sobre ela e depois que eu estava dentro dela eu perguntei se ela me amava. Ela respondeu que estava tentando, mas às vezes era difícil e ela sentia que era difícil. Quando ela falava essa frase eu pensei que ela iria chorar novamente, mas ela não chorou. Depois eu e ela estávamos cansados e ela olhava para mim tranquila e infantil. [...] ${ }^{188}$

É na aproximação sexual com Marilyn Monroe que se revelam as características mais humanas e individuais do narrador. Georges Bataille notou que o erotismo é um dos traços da vida interior do homem. "O erotismo do homem difere da sexualidade animal justamente por colocar em questão a vida interior". ${ }^{189}$ Esse capítulo servirá como uma nota quase realista em relação aos demais. Ele funciona como uma espécie de idílio, o momento de suspensão da "ação dramática". Podemos, com ele, fazer a leitura de que todos aqueles elementos de que o autor lança mão para produzir os demais capítulos, elementos da sociedade ultra tecnológica, animalizam o homem, barbarizam-no, anulando justamente a cultura, o que ele tem de civilizado. Talvez seja na realização erótica que o homem se afirma.

Ser múltiplo como os demais do romance, Marylin Monroe também é representada como esposa do jogador de basebol norte-americano Joe DiMaggio, com quem ela de fato foi casada. Na narrativa, essa relação provoca o ciúme do narrador, que tem DiMaggio como antagonista. Em mais de uma ocasião, o "Eu" se vê obrigado a guerrear com o jogador de beisebol. Como Marylin, DiMaggio assume diversas formas ao longo do livro. Ainda assim, mesmo na realidade fantástica de PanAmérica, há cenas em que o casal Marilyn e DiMaggio não provoca qualquer reação no narrador.

O acúmulo é um dos elementos que chamam a atenção em PanAmérica. Há o acúmulo de ações que se sucedem de modo frenético, sem pausas ou digressões, o acúmulo de imagens sugeridas pelo narrador a cada instante, o acúmulo de seres que com ele contracenam e dos lugares por onde ele passa. Romance do excesso, em que tudo é hiperbólico, PanAmérica vai frequentemente multifacetar e deslocar as representações. Marilyn Monroe, por exemplo, em

\footnotetext{
${ }^{188}$ Idem, ibidem, p. 60.

${ }^{189}$ BATAILLE, Georges. O erotismo. Tradução de Fernando Scheibe. Belo Horizonte: Autêntica, 2014, p. 53.
} 
diversas passagens vista como "tranquila e infantil”, a exemplo do herói DiMaggio, assumirá formas por vezes deformadas ou monstruosas.

Marilyn Monroe agachou sobre os joelhos, abriu as pernas e lançou um horrível lamento, e de sua vagina vermelha escapou em grandes hordas o exército de fetos. A multidão minúscula de fetos abandonou o útero de Marilyn Monroe armada de lanças e espadas. Os fetos rosados de dez centímetros de altura corriam uns sobre os outros nos cantos das lojas e entravam nos bueiros da avenida. Marilyn Monroe jorrava multidões de fetos rosados e vermelhos, que deslizavam encolhidos pelas ruas e subiam uns sobre os outros e cobriam homens e mulheres, destruindo-os com seus afiados dentes. ${ }^{190}$

O excesso percorre o livro do começo ao fim em um avançar quase onívoro que culmina no caos. Praticamente não há elemento em PanAmérica que não seja fantástico. Pensemos naquela cena inicial do diretor de cinema, que parte de um pressuposto realista, ou ainda na relação do protagonista com Marilyn Monroe, que confere, principalmente nas cenas de relacionamento íntimo, um efeito de realidade ou uma suspensão da ação delirante do romance, e veremos que, mesmo quando o livro resvala o realismo, esse realismo não basta, extrapola, deforma-se.

O uso recorrente de imagens que se alternam rapidamente, de ações que se sucedem e de elementos que se inserem na narrativa de modo surpreendente, mais do que deformar a realidade, desloca a noção de representação das coisas e dos seres a que o autor recorre. E esse deslocamento ameaça as próprias categorias ficcionais. É assim que, de saída, a realidade regride (ou avança) até atingir a condição mitológica. Nesse lugar, nessa esfera, será configurada uma nova realidade, onde tudo ou praticamente tudo será possível. É justamente aí, no lugar onde se dão as ações extraordinárias, que o romance tem força.

Alegoricamente, a rapidez das cenas fantásticas busca representar a velocidade do mundo contemporâneo. E não podemos deixar de observar que há, por trás da realização do

${ }^{190}$ PAULA, José Agrippino de. PanAmérica. Rio de Janeiro: Tridente, 1967, p. 217. 
livro, um deslumbramento e, ao mesmo tempo, uma ironia diante desse mundo. Talvez até mesmo um medo de enfrentá-lo, a exemplo do que ocorre com o narrador de Lugar público. PanAmérica revela uma propensão caótica que quase ameaça a própria ficção, com seu deslocamento incessante e radical das categorias ficcionais. Isso, evidentemente, não desloca a obra do universo da ficção, colocando-a em outra esfera. Tampouco faz com que extrapole o gênero do romance que, como vimos, opera com uma liberdade absoluta. Mas, diante da recusa de Agrippino à organização racional, PanAmérica torna-se um romance de difícil classificação - daí a aguda percepção do autor ao associá-lo ao modelo clássico grego.

Se ao final de Lugar público o protagonista "entra na sala de projeção escura e fixa os olhos nas imagens brilhantes", ${ }^{191}$ no final de PanAmérica o narrador vai projetar-se para fora do universo e o fluxo de acontecimentos desse desfecho, um fluxo de superconsciência, faz o "Eu”, juntamente com seres reais e imaginários, históricos e mitológicos, extrapolar os limites do mundo físico do próprio universo fantástico que compõe a narrativa para vislumbrar um possível retorno. E a visão restitui a ordenação de um mundo experimentado ao extremo.

${ }^{191}$ PAULA, José Agrippino de. Lugar público. Civilização Brasileira, Rio de Janeiro, 1965, p. 218. 


\section{CAPÍTULO 3}

\section{ROTEIROS DE VIAGEM}

Escrevo sem conceber, sem tempo real.

José Agrippino de Paula

\section{Narrativas curtas}

Quando PanAmérica foi publicado, em 1967, Nogueira Moutinho escreveu uma crítica hesitante, que revelava certo constrangimento diante da obra, bem ao contrário do entusiasmo com que falara sobre Lugar público dois anos antes. O olhar do crítico não deixou de perceber que o livro colocava questões ao próprio autor.

[...] O caminho tomado por José Agrippino de Paula nesta sua obra é assim um dos mais modernos e dos que mais a crítica hesita em reconhecer. Por esse motivo considero PanAmérica um momento de transição em sua obra, livro que certamente irá condicionar a opção futura do escritor. [...] $]^{192}$

A opção futura de Agrippino não envolveria somente o campo literário. Como vimos, no período imediatamente posterior ao lançamento do livro ele dirigiu peças e produziu filmes.

Depois da publicação da epopeia, como que confirmando a vocação pop do romance, o escritor trabalhou em uma adaptação do livro para os quadrinhos. Esse trabalho, intitulado talvez provisoriamente de "O cego", seria ilustrado por Antonio Dias. De acordo com o artista plástico, Agrippino lhe entregou um roteiro sobre o qual ele começou a fazer os desenhos, mas o trabalho não foi concluído. Hoje, Dias guarda os originais de "O cego" em seu ateliê de Milão, na Itália, e parte dos desenhos feitos a partir do roteiro integra a coleção de inacabados do crítico e historiador de arte suíço Harald Szeemann. ${ }^{193}$

\footnotetext{
192 MOUTINHO, José Geraldo Nogueira. “Panamérica”. In: A fonte e a forma. Rio de Janeiro, Imago, 1977, p. 54.

${ }^{193}$ Entrevista de Antonio Dias ao autor.
} 


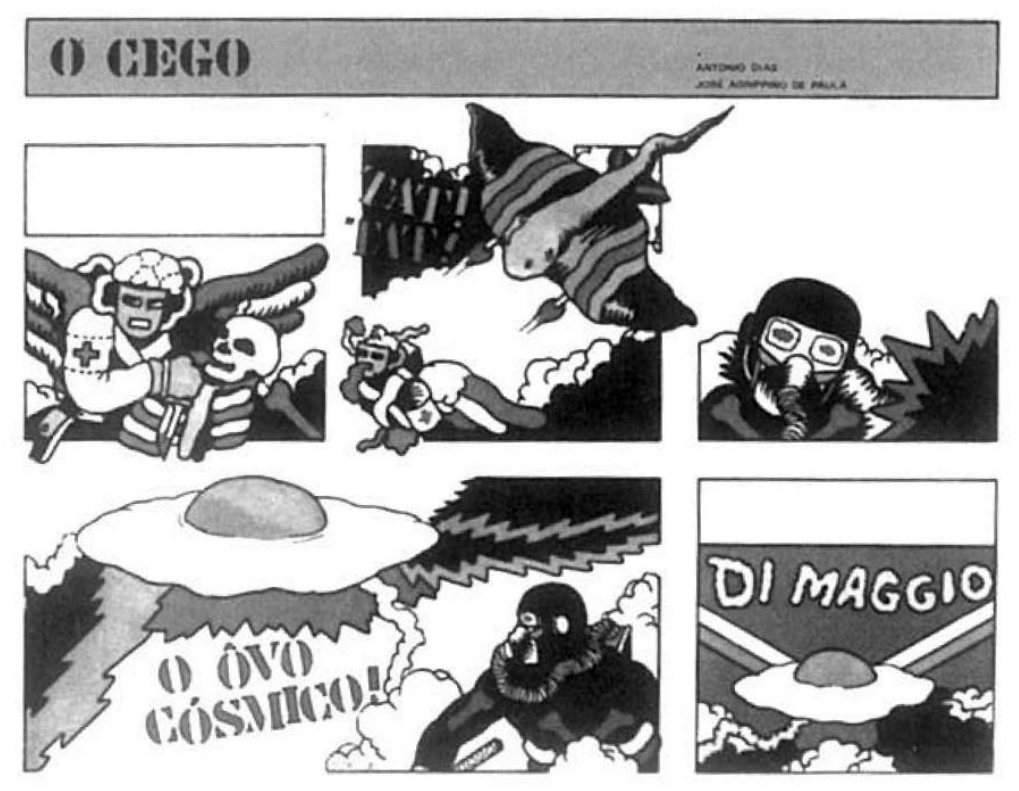

Nos anos 1970, Agrippino publicou quatro breves narrativas. Optamos por chamá-las de narrativas por terem sido produzidas dentro da liberdade com que o autor concebia a escrita. Esses textos, com exceção de um deles, são relatos de experiências pessoais transfigurados por um narrador ficcional em primeira pessoa, um pouco como ocorre com a apropriação dos diários em Lugar público.

Como em seu primeiro romance, as narrativas recontavam algumas das vivências do escritor naquela década, quando viveu no exílio na África e no litoral da Bahia.

A primeira delas foi escrita em 1972, em Tanger, no Marrocos. Chamava-se "Roteiro de viagem do diário oficial das drogas do Ocidente" e flagrava uma situação cotidiana do narrador ao lado de sua mulher na África. O texto foi publicado em 1976. "Na alameda dos baobás", que trazia outra situação africana, e "A cigana prateada da lua", sobre uma personagem hippie que vem do Chile para o litoral baiano, foram, ambos, publicados em 1977. Localizamos ainda um texto inédito e sem data, intitulado "Som do divino maravilhoso", produzido provavelmente no mesmo período. Além deles, Agrippino ainda publicou "Tribo do mar e do ar sagrado", classificados como "fragmentos de um livro" e que abordaremos mais adiante. 
O "Roteiro de viagem do diário oficial das drogas do Ocidente" é um texto confessional que traz um dia na vida do narrador estrangeiro em meio a crianças de uma comunidade árabe no mês do Ramadã. As privações que o jejum religioso provoca nas personagens culminam na privação afetiva do próprio narrador, que se depara com sua mulher doente chamada Maria. Vejamos um trecho:

[...] Eu comecei a andar na areia pesada com passos largos e lentos e comecei a chorar e repetir na cabeça "C'est pour ma femme, elle avais faim", e chorava uivando de dor e as lágrimas corriam pelo rosto molhando a barba. Ela tinha uma fome insaciável e eu gritava chorando e sabia atravessando a mata com o prato de sopa na mão direita que ela seria sempre insaciável, e andava lentamente no escuro uivando de dor e chorando e lentamente pisava nas folhas secas e chorava. A luz da lua muito forte e branca abria na floresta sombras das árvores, e eu atravessava uivando de dor o mais alto que podia, o vento era muito forte e fazia muito barulho e segurava com os cinco dedos a boca da tigela de sopa. [... ${ }^{194}$

"Na alameda dos baobás", a exemplo do "Roteiro", é uma narrativa africana em primeira pessoa. Como no "Roteiro", os interlocutores do narrador têm o mesmo nome de alguns dos companheiros de viagem de Agrippino pela África: Maria Esther e José Ramalho. $\mathrm{O}$ conto trata da morte de um dos meninos que costumavam brincar com o narrador.

Um dia eu voltei de Dakar pelo barco e quando entrei na venda onde eu não pagava os pastéis de peixe a velha negra que dizia que era minha mãe me disse que tinha morrido um menino na barca. A velha Aminatá disse que o barco veio e a maré estava jogando e o menino foi prensado entre a barca e o porto. Maria Esther e Ramalho já tinham voltado para o Brasil e eu estava lá dormindo com sleeping-bag ao lado dos compridos canhões de segunda

${ }^{194}$ PAULA, José Agrippino de. "Roteiro de viagem do diário oficial das drogas do Ocidente". In: Revista Azougue $\mathrm{n}^{\circ}$ 8. Rio de Janeiro, abril de 2003, p. 87. 
guerra no topo da ilha. Eu estava muito sensível a tudo e quando a velha Aminatá me falou da morte do garoto eu procurei me lembrar quem era. Alguns dos meninos eu tinha relação de que quando eu chegava na praia fazíamos uns gestos de Kung Fu e dávamos uns gritos. Lá em Dakar passavam muitos filmes de Kung Fu. Não consegui me lembrar do menino e fui andando nas ruas da ilha batidas por um sol muito brilhante e forte. No fundo de uma rua embaixo de uma árvore estavam umas mulheres africanas sentadas nas esteiras, e em frente a casa umas cadeiras vazias em fila encostadas a parede e um senhor negro sentado de óculos escuros. ${ }^{195}$

“A cigana prateada da lua”, também narrado em primeira pessoa, tem uma temática um pouco diferente das anteriores. Aqui, é relatada uma cena em uma comunidade hippie da Bahia. Da atmosfera, é possível perceber algumas das características daquela geração. A Cigana, uma estrangeira que opta pela vida comunitária no litoral brasileiro, tem sua vida relatada pelo narrador, também membro daquele grupo.

Era um som que não ofendia a natureza. Saia como que das folhas e do vento. E a Cigana Prateada da Lua ficava parada muito tempo como uma árvore. Depois do candomblé de noite um ogã pagou vinho de jurubeba pra mim e charuto para ela e foi abraçando e rindo pra todo mundo. Era um dia sem interesse para todos, mas tudo acontecia no mar. Foi ela que me levou pela mão pra ver o mar. E tinha muitos carros de noite com faróis iluminando a gente no mato e depois aquela longa estrada de asfalto ao longo da praia. E foi indo muito longe aquela estrada cheia de carros e eletricidade. Era uma cidade eletrônica lutando contra o mar. O mar era uma água viva como a água viva transparente do mar. Uma só água viva o mar envolvia o planeta e respirava e fervia espuma branca nos poros e depois era muito o final de uma época, mas o mar ia vencer porque era a natureza e ninguém vence a natureza que é muito infinito sem fim. Aí foi chegando um tempo em que o mar escuro era um só ser vivo contra a terra dos continentes. Aí foi chegando um tempo em que o mar escuro era um só ser vivo contra a terra do continentes. Aí foi

${ }^{195}$ PAULA, José Agrippino de. "Na alameda dos baobás". In: Revista Caspa no 1, revista de Letras da USP, Cael, 1977a. 
chegando um tempo em que muito mal ver esfinge parada em silêncio no escuro. Aí eu fui comer arroz. Estava um pouco duro o arroz. Era muito arroz. Ela ficou dormindo lá fora envolta no casaco velho de pele. Quando ele chamava muitas vezes era para despertar o outro espírito. Depois no Chile existiam os terremotos e ninguém podia andar e todo mundo caía. Quando andava a terra tremia muito. Foi depois o mar recuou muito e depois veio uma onda gigantesca escura. Era o deslizamento de grandes extensões de areia do fundo do mar. Depois vinham os longos abraços que vinham do fundo do mar. Era muito forte aquele fim de mundo. ${ }^{196}$

Fora trechos dos diários dos anos 1960 que seriam publicados nos anos 1980, “A cigana prateada da lua" seria o último trabalho publicado em vida por Agrippino. O "Som do divino maravilhoso", que trazemos como anexo a este trabalho, trata do Hare Krishna ${ }^{197 .}$ Nesse texto, o narrador também comenta a vida de personagens de uma comunidade litorânea, revelando conhecimentos de religiões orientais e permeando-os com fatos vividos em seu próprio cotidiano.

Sendo o Criador era completo e partiu no seu planeta em busca da luz. A luz é a iluminação e foi Brahma deus supremo viajando no espaço escuro em busca de luz. O espaço escuro e vazio de matéria era imenso e Brahma sobre o seu planeta, o Planeta de Brahma, Planeta Bramânico. Não sei quantas eternidades ou quantos anos Bramânicos, que são milhões de anos, viajou Brahma no espaço escuro e não encontrou a luz. ${ }^{198}$

${ }^{196}$ PAULA, José Agrippino de. “A cigana prateada da lua”. In: Revista Ficção no 19, julho de 1977b, p. 18 e 19.

${ }^{197}$ O texto, conservado por Guilherme Henrique de Paula e Silva, foi escrito em uma lauda do jornal Tribuna da Bahia. Suspeitamos que date da segunda metade dos anos 1970, período em que Agrippino morou em Salvador.

198 "Som do divino maravilhoso". Inédito. S. d. 
Comparados aos romances, esses textos têm menos força. São obras de um artista em que vida e obra passaram a se integrar de um modo que torna impossível - e inútil identificarmos, a partir do material narrado, onde há a descrição da vida e onde há a invenção.

Se em PanAmérica os experimentos temáticos foram levados ao extremo, as narrativas curtas reposicionam o narrador no cotidiano. Nelas, do mesmo modo que em boa parte de Lugar público, predomina o aspecto autobiográfico. Agora, a exemplo de seu livro de estreia e ao contrário de PanAmérica, a psicologia agora volta a ganhar importância.

$\mathrm{O}$ "Roteiro de viagem do diário oficial das drogas do Ocidente" e "Na alameda dos baobás" trazem personagens com nomes reais. Apesar de o narrador não ter nome - outro traço comum aos narradores de Agrippino -, as figuras com as quais ele interage repetem os nomes próprios de companheiros de jornada do escritor.

Outro elemento comum a essas narrativas é que elas prescindem da temática urbana que sobressai nos livros. São peças realistas, mas de uma realidade alternativa em relação à vida burguesa. A voz do narrador situa os relatos em realidades distintas, seja a africana ou aquela vivida em comunidades do litoral brasileiro. Com elas, em certo sentido, Agrippino parece seguir um movimento de abandono da ficção, ainda que esse abandono seja apenas aparente.

\section{Terracéu}

“A cigana prateada da lua" foi publicado pela Revista Ficção em julho de 1977. Acompanhando o texto, uma nota dizia que o autor era um "paulista radicado na Bahia" que “viajou para o Oriente". Mas o que chama atenção é a informação de que Agrippino "tem dois romances inéditos". 199

Talvez depois de ter terminado PanAmérica, principalmente durante o período em que viajou pelo estrangeiro e no tempo em que viveu na Bahia, Agrippino dedicou-se a uma obra que se chamaria Terracéu.

\footnotetext{
${ }^{199}$ Paula, José Agrippino de. “A cigana prateada da lua”. In: Revista Ficção no 19, julho de 1977b, p. 16.
} 
Tudo o que nos chegou do livro foram fragmentos. Ainda que seja extremamente difícil comentarmos o projeto, uma vez que grande parte do material se perdeu, ele é importante porque, nos parece, seria mais uma obra experimental que iria se apropriar de mitologias, desta vez mais primitivas do que aquelas exploradas em PanAmérica.

O método de composição teria sido o mesmo empregado nos anteriores. Agrippino escrevia algumas passagens soltas para, no futuro, organizá-las. Se em PanAmérica ele recorria a mitos da sociedade contemporânea, agora a narrativa se apropriava de elementos míticos pós-apocalípticos com características de ficção científica.

Enquanto seu último trabalho no gênero fora por ele classificado como "epopeia", Terracéu seria o "livro sagrado" de um povo quase imemorial. Nele, o autor procurava descrever os elementos fundadores da mitologia de um povo não localizado na História, provavelmente vivendo numa era posterior à das "nações unidas".

De acordo com Evelina Hoisel, que conheceu Agrippino por volta de 1975, quando o procurou para estudar PanAmérica, o autor dizia que esse livro era "inspirado nos hexagramas do i-ching". A revelação não surpreende, se tivermos em mente que, também segundo Evelina, ele dizia que PanAmérica tinha por trás de sua composição a noção de Demócrito sobre o átomo. O escritor chegou inclusive a ceder-lhe uma cópia do manuscrito do livro, material que ela ainda guarda. ${ }^{200}$

Em Naquele tempo em Arembepe, o arquiteto e escritor Beto Hoisel, marido de Evelina, recria situações vividas naquela época na Bahia, onde o casal conviveu com Agrippino. Em uma das passagens, o narrador conversa com um certo Zé Agostinho, autor de um livro chamado na narrativa de "Panamericana" e que no presente da narrativa trabalha num novo projeto:

- E agora, Zé? O que é que você está escrevendo?

- Ah! É coisa bem diferente...

- Romance?

\footnotetext{
${ }^{200}$ Entrevista de Evelina Hoisel ao autor.
} 
- Acho que não... É uma coisa diferente... Pode ser até que o pessoal da literatura chame de romance, mas o gênero, mesmo, é o de um livro sagrado.

- Como é? Livro sagrado?

- É... O livro sagrado de um povo... de um lugar... não sei onde é. É isso: a história do menino da cabeça grande. O livro sagrado de um povo de um lugar. ${ }^{201}$

Depois de Agostinho emprestar à personagem Princesa, esposa do narrador, algumas páginas do livro, ela comenta com o marido:

- Não me parece que ele esteja querendo recriar uma cultura primitiva do passado. O que o texto do novo livro me sugere é o mito de uma cultura aparentemente primitiva, mas herdeira de uma visão científica das origens do cosmos, do planeta Terra e da vida, como se fosse a cultura de um povo pósapocalíptico. De algum povo futuro que retém caoticamente na memória inconsciente algo como uma visão científica terrivelmente deformada, como num recomeçar do mundo pós-nuclear. ${ }^{202}$

Caetano Veloso, que conviveu com Agrippino no período baiano e que costumava hospedar o escritor quando Agrippino ia ao Rio de Janeiro, falou sobre esse livro em seu prefácio para a terceira edição de PanAmérica:

Depois de PanAmérica ele começou a escrever um novo texto longo que, nas antípodas da superpoluição urbana, se voltava para uma mitologia e uma simbologia da natureza como perene utopia realizada: Terracéu. Ele nunca concluiu esse romance (não seria um romance, mas como chamá-lo?). 203

\footnotetext{
${ }^{201}$ HOISEL, Beto. Naquele tempo em Arembepe. $2^{a}$ edição. Salvador: Século 22, 2003, p.110.

202 Idem, ibidem, p. 157.

${ }^{203}$ VELOSO, Caetano. "Prefácio". In: PanAmérica. $3^{a}$ edição. São Paulo, Papagaio, 2001, p. 8.
} 
Em entrevista para este trabalho, Caetano diz:

Ele me deu algumas (nem tão poucas) páginas para ler. Tinha aquele misto de primitivismo com ficção científica que marcava a personalidade dele. Só que dessa vez era o aspecto primitivo, natural, que predominava - e com alegria. Era o oposto de PanAmérica quanto a isso. ${ }^{204}$

Como se vê, havia nesse texto o problema do gênero e da forma. Não se sabe o que teria levado Agrippino a abandonar o projeto. Em uma de suas últimas entrevistas, ele disse que remeteu para São Paulo, a partir da capital inglesa, um "romance que escrevia em Londres, chamado Terracéu", mas a bagagem foi extraviada e o livro se perdeu. ${ }^{205} \mathrm{Se}$ isso aconteceu, podemos concluir que Agrippino tinha mesmo começado a trabalhar no livro no exílio e, depois do extravio, retomou o projeto na Bahia.

Em agosto de 1974, o que parecem trechos dessa obra foram publicados pela Revista Planeta sob o título "Tribo do mar e do ar sagrado" seguido pela indicação "quatro fragmentos de um livro". Ainda que o nome do livro não seja mencionado pelo periódico, tudo nos leva a crer que se tratasse de fragmentos de Terracéu. Em 9 de junho de 1976, Agrippino escreveu ao então presidente da Fundação Nacional do Índio (FUNAI), o general Ismarth de Araújo Oliveira, solicitando "contato com uma tribo durante os rituais específicos dos ancestrais". Depois de se apresentar, ele diz: "estou escrevendo um livro e já publiquei alguns fragmentos nas revistas Planeta e Ânima".

A inclusão da Ânima no texto parece exagerada, já que, até aquele momento, a publicação tinha apenas um número, justamente o que trazia a narrativa "Roteiro de viagem do diário oficial das drogas do Ocidente”, que não parece ter qualquer relação com a temática explorada pelo autor em Terracéu.

\footnotetext{
${ }^{204}$ Entrevista de Caetano Veloso ao autor.

${ }^{205}$ BRESSANE, Ronaldo e TERRON, Joca Reiners. "O Desfavorecido de Madame Estereofônica”. In: Revista Trip, São Paulo, junho de 2007a.
} 
Já o material publicado na Revista Planeta traz um conteúdo mítico que emula textos sagrados. Evelina Hoisel nos disse que esses fragmentos estão relacionados ao livro. ${ }^{206}$ Vejamos um deles:

Foi num continente que não encontraram os ancestrais. Estavam faltando os ancestrais e depois o que fazer. Não tinham mais flechas e era muito tempo sem fazer nada. Que poderia ser aquela de virar o tempo? E depois era muito verdadeiro e quem poderia? Era muita gente falando no parque e discursando contra ou a favor, e quem poderia sentir um calor e depois ir e ver se realmente era verdadeiro voltar, mas quem poderia encontrar o verdadeiro ancestral? Eram muitos ossos humanos debaixo da terra e aqueles espíritos vagando soltos na terra. E quem seria o ancestral? Poderia ser aquele muito distante. Que machado ele poderia usar e depois eram muitos aparelhos eletrônicos buscando os ancestrais. Era uma pesquisa que não poderia agradar aos velhos, e os velhos ficavam ali sentados debaixo da sombra do baobá, e o chefe velho estava encostado no tronco grosso da árvore. Todos os velhos de cajado e espantando as moscas com o rabo de cabrito. Eles levavam presas na orelha umas folhas: era para indicar que eles tinham vindo das folhas. Porque os ancestrais do cisne eram os dinossauros de pescoço longo que viviam nos lagos. $\mathrm{O}$ ancestral depois varou as nuvens e veio descendo. Atravessava um faixo de luz e descia imóvel. Era muito grande e não se via a cabeça; só a luz forte na nuca atravessando os cabelos. E brilhava muito e atravessava as nuvens. ${ }^{207}$

Podemos observar pelo texto, um dos quatro fragmentos, que sobressai, mais uma vez, o elemento mítico, agora em função de um primitivismo que convive com a presença de aparelhos eletrônicos.

\footnotetext{
${ }^{206}$ Entrevista de Evelina Hoisel por telefone ao autor em 28 de julho de 2014.

207 PAULA, José Agrippino de. "Tribo do mar e do ar sagrado: quatro fragmentos de um livro". In: Revista Planeta $\mathrm{n}^{\circ} 24$, São Paulo: Editora Três, agosto de 1974, p. 94.
} 
Em 1977, o segundo e derradeiro número da Revista Ânima publicou um texto chamado "Reportagem astral na praia do Cheganêgo". ${ }^{208}$ Trata-se de um depoimento sobre um espetáculo referido como "O espírito menino do planeta Terra", encenado com crianças de comunidades de candomblé de Salvador. A montagem, ao que tudo indica, foi precária e cercada de improviso. "Era muita desordem. As crianças foram incrivelmente sem respeito e sem concentração", disse Agrippino. ${ }^{209}$

Caetano Veloso, que viu o espetáculo, nos disse que foi "uma experiência teatral única e muito à frente do seu tempo (como o Tarzan tinha sido), mas ficou esquecida". ${ }^{210} \mathrm{O}$ comentário do compositor é importante porque a peça, ao que parece, utilizava elementos explorados em Terracéu, o que poderia justificar a inclusão da Revista Ânima por Agrippino naquela carta endereçada à Funai. É possível que os textos depois publicados nesse segundo número fossem parte do material que o autor pretendia utilizar na narrativa que já estivessem em poder dos editores quando Agrippino escreveu a carta, antes, portanto, do lançamento da segunda edição da revista.

Assim como o Rito do amor selvagem montava cenas de As Nações Unidas, "O espírito menino do planeta Terra" mantinha relações diretas com a temática explorada no romance inacabado. Vejamos como Agrippino se referiu à montagem:

era uma alma, a alma do Planeta. O corpo do homem é cheio de pelos e tem unhas. E os pelos e as unhas são o corpo mineral do homem que poderá ser cortado sem ferir. O Planeta Terra também tem o seu corpo mineral como o cabelo, e o seu corpo vivo que é o mar. O mar como a pele no corpo humano é uma parte viva, cheia de células, de micro-organismos e algas. O planeta comum. Os outros, Marte, Vênus, Júpter, já são mortos ou talvez bactérias em algum canto. Mas nunca seria assim como na Terra cheio de vida, abundante de vida em todos os lados. ${ }^{211}$

\footnotetext{
${ }^{208}$ Publicação criada pelos letristas Abel Neto e Antônio Carlos Capinan que teve apenas dois números. Ambos contaram com a colaboração de Agrippino.

209 "Reportagem astral na praia do Cheganêgo". In: Revista Ânima n 2. Rio de Janeiro, abril de 1977c, p. 16.

${ }^{210}$ Entrevista de Caetano Veloso por e-mail ao autor em 19 de junho de 2012. Caetano refere-se ao espetáculo Tarzan III Mundo, o mustang hibernado.

211 "Reportagem astral na praia do Cheganêgo". In: Revista Ânima n ${ }^{\circ}$. Rio de Janeiro, abril de 1977c, p. 15. 
Quanto ao outro romance mencionado na nota de apresentação do autor na Revista Ficção, não temos nenhum conhecimento.

Juntamente com Lugar público e PanAmérica, "Tribo do mar e do ar sagrado", "Roteiro de viagem do diário oficial das drogas do Ocidente", "Na alameda dos Baobás" e "A cigana prateada da lua", além de "Som do divino maravilhoso", "encerram" a produção literária mais consciente e, podemos dizer, consistente do autor.

\section{Fortuna crítica}

A recepção crítica parece um sintoma do deslocamento dos livros de José Agrippino de Paula. Em 1967, o jornal Folha de S. Paulo publicou uma matéria não assinada que convocava para o lançamento de PanAmérica. O texto dizia que Agrippino "causou sério impacto na crítica, nos leitores e na jovem geração universitária paulistana e carioca" com Lugar público, e destacava esse livro como "experiência inédita no campo da ficção urbana, dada sua característica principal: é uma obra cíclica, na qual os personagens, anti-heróis, permaneciam na sua inatividade e distanciamento do mundo".

Além disso, o artigo aproximava Agrippino de "Dangling Man" e "Herzog", de Saul Bellow, ${ }^{212}$ já que as personagens dessas obras, como em Lugar público, "permanecem na mesma recusa de participação do mundo.” Apesar de enaltecer a conexão de Agrippino com as modernas técnicas de ficção, o texto apontava, já naquele ano, a dificuldade de leitura e de absorção da obra do autor.

Todavia, apesar de já haver superado esse livro, Agrippino permanece em situação praticamente inédita, pois a novelística atual brasileira não ultrapassou a narrativa linear e a preocupação psicológica,

${ }^{212}$ Em 1967, Dangling man foi publicado no Brasil com tradução de Ana Maria Machado intitulada Por um fio. 
totalmente ausentes de seu livro. Em resultado dessa dificuldade de leitura, "Lugar Público" não foi deglutido, provocando a perplexidade e mesmo a omissão de alguns críticos, que se confessaram incapazes de compreendê-lo por não estarem atualizados com as formas de ficção contemporânea, no exterior. $^{213}$

Assim, mesmo tendo saído por uma das principais editoras do período, a Civilização Brasileira, e com prefácio de Carlos Heitor Cony, jornalista conhecido no meio literário e um dos novos romancistas que despontavam naquela época, ${ }^{214}$ Lugar público não teve grande repercussão. Quando lançado, o romance recebeu uma resenha de Nogueira Moutinho. O livro ainda foi mencionado por Nelson Werneck Sodré em um artigo de balanço sobre a produção literária de $1965 .{ }^{215}$ Já PanAmérica, além da citada crítica também de Moutinho, não despertou a atenção dos comentadores. A obra, ainda mais radical que Lugar público, saiu por uma editora menor, o que certamente não contribuiu para sua divulgação.

Talvez o caráter inovador desses textos e a proposta radical da escrita, principalmente de PanAmérica, estivessem muito distantes do trabalho não só dos contemporâneos de Agrippino como também da tradição do romance brasileiro. Talvez os textos estivessem distantes até mesmo do período, antecipando questões ainda apenas vislumbradas. Exemplo disso é a internacionalização do território narrativo de PanAmérica, que configura um mundo globalizado em um tempo em que a globalização dava seus primeiros e tímidos passos.

Se no âmbito da cultura brasileira a década de 1960 não era muito propensa à prosa de ficção, aspecto abordado por Evelina Hoisel em Supercaos, dentro do segmento talvez o momento não fosse favorável às radicalizações propostas por Agrippino. Em trabalho mais recente, a estudiosa voltou a chamar atenção para a originalidade do segundo livro do autor.

[...] PanAmérica anunciava, no contexto cultural brasileiro, de maneira precursora e contundente, o processo de democratização do literário, rompendo com as dicotomias estabelecidas entre alta/baixa literatura,

\footnotetext{
213 "Panamérica", uma epopeia continental. Autoria não creditada. Folha de S. Paulo, São Paulo, 16 ago 1967.

${ }^{214}$ Dizemos novo romancista sem qualquer relação com o Novo Romance, mas sim porque o autor havia estreado na literatura em 1958.

${ }^{215}$ SODRÉ, Nelson Werneck. "O movimento literário". In: Revista Civilização Brasileira n 7, maio de 1966.
} 
literatura erudita/literatura popular, literatura/paraliteratura, estético/não estético.

Delineando um vasto painel da sociedade do espetáculo, expondo as diversas feições da civilização e da barbárie (ou da civilização como barbárie), a narrativa de PanAmérica movimenta-se através de variadas fronteiras multiculturais, cartografando os processos de globalização que caracterizam o capitalismo internacional. De maneira paradoxal, PanAmérica registra o processo de globalização emergente na sociedade contemporânea, articulando-se a partir do Brasil, um país da América Latina econômica e tecnologicamente subdesenvolvido, na fase de expansão do imperialismo dos Estados Unidos. ${ }^{216}$

A epopeia de Agrippino não deixou de abordar e problematizar o contexto histórico, político e social em que o livro foi produzido, só que o fez em uma esfera mais abrangente, com um herói em tudo oposto à individualidade que tradicionalmente caracteriza o gênero romanesco. Outras obras que dialogavam com o momento como Quarup, de Antonio Callado, e Pesach, a travessia, de Carlos Heitor Cony, igualmente publicadas em 1967, mostraram-se mais adequadas à tradição realista da literatura brasileira, fiel ao documental e ao retrato social e do momento histórico.

Foram justamente esses os livros citados por Roberto Schwarz em seu trabalho sobre a cultura e a política do momento em que os romances de Agrippino foram publicados. Diz o crítico: “o tema dos romances e filmes políticos do período é, justamente, a conversão do intelectual à militância". ${ }^{217}$ Em suas aventuras, o cineasta de PanAmérica também se converte e milita, mas em uma esfera distinta das referencialidades históricas daquele contexto brasileiro.

Mesmo em relação ao tropicalismo, importantes estudos sobre o movimento como o de Celso Favaretto, defendido em 1979 e publicado no mesmo ano, além do citado ensaio de Roberto Schwarz, não fazem sequer menção à obra de Agrippino.

${ }^{216}$ HOISEL, Evelina. "PanAmérica: uma cartografia dos processos de globalização nos anos de 1960". In: Recôncavos (Revista do Centro de Artes, Humanidades e Letras vol. 2 (I), 2008, p. 2.

${ }^{217}$ SCHWARZ, Roberto. "Cultura e política, 1964-69”. In: O pai de família e outros ensaios. São Paulo, Companhia das letras, 2008, p. 84. 
Daquela década de 1960, aliás, fora os casos excepcionais de Clarice Lispector e de João Guimarães Rosa, autores já então consagrados, poucas experiências divergentes da tradição da nossa narrativa literária ganharam a atenção da crítica, como ocorreu com Osman Lins e de Campos de Carvalho.

Nem mesmo os chamados poetas concretos, que desenvolveram um importante trabalho crítico de resgate, apresentação e valorização de escritores de vanguarda para estabelecer o seu paideuma, deram atenção ao trabalho de Agrippino. Ainda que seus esforços de centrassem na poesia, Haroldo de Campos, por exemplo, preferiria comentar o romance experimental Catatau, de Paulo Leminski, nos anos 1970.

Em estudo que trata da formação dos cânones literários e analisa as preferências de autores consagrados, Leyla Perrone-Moisés fala sobre a recepção da obra literária e a função da leitura para sua existência.

[...] Os teóricos da literatura do século XX têm insistido na correlação escrita e leitura. Desde que as verdades começaram a faltar, estabeleceu-se que a leitura não descobre o que a obra contém, em sua verdade essencial, mas literalmente recria a obra, atribuindo-lhe sentido(s). A leitura foi reconhecida como condição para a existência da obra. Ao mesmo tempo, considerou-se que toda obra nova implica, em sua fatura como em sua recepção, uma releitura do passado literário. Uma obra ainda está viva quando tem leitores. Os teóricos da 'estética da recepção' enfatizaram o papel do leitor na própria produção literária, sua influência sobre as direções subsequentes dessa produção. [... $]^{218}$

Apenas recentemente a obra de Agrippino começou a ganhar mais atenção de leitores especializados. Durante anos, o estudo de Evelina Hoisel permaneceu isolado. Sem crítica, a obra permaneceu em silêncio.

Depois da primeira edição, PanAmérica não voltaria ao prelo pelos próximos vinte anos, tendo permanecido obscuro para a crítica e desconhecido do público leitor. Do mesmo

${ }^{218}$ PERRONE-MOISÉS, Leyla. Altas literaturas: escolha e valor na obra crítica de escritores modernos. São Paulo, Companhia das Letras, 2009, p. 13. 
modo, Lugar público levaria trinta e nove anos para voltar ao mercado, o que aconteceu apenas em 2004.

Ao longo dos anos, autor e obras marginais acabaram eclipsados pelo contexto em que apareceram. Corpo estranho na literatura brasileira, PanAmérica, "uma das arestas da total tragédia do nosso século”, nas palavras de Nogueira Moutinho, acabou, contudo, beneficiado pelo meio em que seu autor circulava, entre artistas plásticos e músicos populares, campo em que o trabalho de Agrippino acabou se tornando reverenciado. E as palavras de Augusto de Campos para se referir a Ulysses servem para PanAmérica: "obra de leitura árdua, destinada mais a produtores que a consumidores". ${ }^{219}$

Apresentado como o mais jovem dos autores que participaram daquele inquérito sobre o romance urbano em 1966, Agrippino disse: "Não trabalho, sou arquiteto sem profissão, não tenho programa de sequências sobre a minha vida". ${ }^{220}$ Depois, ele continua: "Escrevo sem conceber, sem tempo real, não sei datilografia e tanto me faz começar pela última como pela primeira página".

Agrippino nunca teve a atitude de um escritor como, por exemplo, Osman Lins, autor também inovador e consciencioso. Em 1966, um ano antes de PanAmérica, portanto, Lins havia publicado Nove, novena, livro que chamou a atenção da crítica pelo experimentalismo formal de suas nove "narrativas". Professor universitário - o que certamente facilitou a penetração de sua obra na academia, onde continua sendo bastante estudado -, o pernambucano radicado em São Paulo fez sua obra sem alarde, no interior do estado, onde lecionava. Em 1969, ele publicou Guerra sem testemunha, livro que tratava das relações do escritor com sua obra e com o mercado editorial. No trabalho, entre outros aspectos fundamentais para a criação literária, Lins chama a atenção para a necessidade das "exigências" da obra, inclusive aquelas feitas por ela aos próprios autores, obrigados e comprometidos com o seu trabalho.

\footnotetext{
${ }^{219}$ CAMPOS, Augusto de. "De Ulysses a Ulisses". In: Panaroma do Finnegans Wake. $4^{\mathrm{a}}$ ed. rev. e ampl. São Paulo, Perspectiva, 2001, 173.

${ }^{220}$ ANTÔNIO, João. "Inquérito: o romance urbano". In: Revista Civilização Brasileira n 7, Rio de Janeiro, Civilização Brasileira, maio de 1966, p. 220.
} 
Nos anos que se seguiram à publicação de "A cigana prateada da lua", mesmo passando por problemas pessoais que o levaram àquele diagnóstico de esquizofrenia, Agrippino continuou escrevendo. Em completo isolamento. A escrita nunca foi, para ele, uma atividade episódica. Quando seus dois romances foram relançados, já nos anos 2000, o autor afirmou em diversas entrevistas que estava trabalhando em uma obra que, àquela altura, chamava de Os favorecidos de Madame Estereofônica. Segundo Agrippino, o livro retrataria os bastidores de uma novela produzida pela TV Cultura e as relações entre atores e produtores. "Atualmente eu procurei voltar para o realismo. Estou escrevendo mais diálogos, com maior quantidade de textos desse gênero do realismo", ele disse a um programa de televisão. ${ }^{221}$ Ainda que não fossem fantásticos como PanAmérica, mais uma vez o autor abordaria a cultura de massa

Fiel ao que chamamos de sua "Poética", nessa entrevista Agrippino se mostrou titubeante para definir o livro como novela.

Eu não sou capaz de escrever uma novela. Eu me considero incapaz porque, para escrever uma novela, você tem que escrever da infância à idade adulta e, em geral, o personagem central, que você denominou o protagonista, morre no fim da novela. Então eu não consegui ser esse narrador.

E ainda acrescentou sobre o método de composição.

Um livro de duzentas páginas exige mais ou menos duas mil páginas de manuscritos. Demora um tempo para escrever um romance, um ano ou dois. A quantidade de manuscritos é muito grande. Eu procuro sempre manter uma regularidade escrevendo trechos pelo menos 15 minutos ou 30 minutos por dia, então vou acumulando material de texto para um romance que eu irei publicar no futuro. Escrevo alguma coisa pretendendo depois ordenar esses manuscritos formando uma história. ${ }^{222}$

221 Programa Lugar Reservado, Sesc TV, 2005.

${ }^{222}$ Idem. 
Nesse ritmo, ele deixou mais de uma centena de cadernos manuscritos, mas morreu sem conseguir ordená-los.

A falta de programa de sequências sobre a vida, aliada talvez à enfermidade de que foi acometido, impediram que Agrippino concluísse um novo romance. Mais do que isso, ela parece ter provocado interferência na história das edições de seus livros, contribuindo para o seu obscurecimento.

A reabilitação começou em 1997, quando, por ocasião dos trinta anos do tropicalismo, Caetano Veloso publicou seu livro de memórias Verdade tropical, em que Agrippino é apontado como um importante interlocutor do compositor durante o ápice do movimento, entre as metades das décadas de 1960 e 1970. O livro de Caetano ajudou, e muito, a colocar o nome de José Agrippino de Paula de volta em circulação, revelando-o a novas gerações de leitores.

Ainda em 1997, dentro das comemorações pelo importante ano de 1967 para a cultura brasileira, Sérgio Sant'Anna, jovem autor revelado no final dos anos 1960 e que desenvolveria uma obra fortemente caracterizada pelo experimentalismo formal, também escreveria sobre Agrippino e PanAmérica.

[...] No escrito de JAP se presentificam exemplarmente, numa linguagem exasperadamente reiterativa e antipsicológica (como um "nouveau roman" que não fosse chato), as mitologias do grande espetáculo de uma época: político, revolucionário, artístico e, obviamente, o cinematográfico, que resume e devora tudo, criando uma suprarrealidade, que aliás é boa parte da realidade mesma de gerações criadas nas salas de cinema, antes do império da TV. Mas, com um ou com outra, de pão e ficção vive o humano. [...] Subliteratura? Não: superliteratura (a fronteira pode ser tênue, bicho). [...] ${ }^{223}$

Poucos anos depois, no ano 2000, Nelson de Oliveira, escritor alinhado com experimentações formais e empenhado em produzir uma obra crítica sobre autores “esquecidos" pela tradição, além de ser o responsável por antologias de autores brasileiros

${ }^{223}$ SANT’ANNA, Sérgio. “A utopia de José Agrippino”. In: Caderno Mais!, Folha de S. Paulo, 23/2/1997. 
surgidos dos anos 1990, também comentou o trabalho de Agrippino. ${ }^{224}$ Recentemente, outros nomes dessa geração como Joca Reiners Terron, Ronaldo Bressane e, principalmente, André Sant'Anna declararam em entrevistas e acusaram em seus próprios escritos as influências que receberam do autor.

Mas foi a partir de 2001, quando uma terceira edição de PanAmérica veio a público, suscitada em grande parte pelos comentários de Caetano Veloso em Verdade tropical, que a obra de Agrippino passou a receber mais atenção. Por ocasião do relançamento, Ricardo Lísias, outro autor surgido naquele período, ressaltou a complexidade e os desafios impostos pelo romance.

A dificuldade para resenhar o segundo livro de José Agrippino de Paula, PanAmérica, [...] não está exatamente na preocupação com o que deixar de fora do comentário, mas sim na consciência de que, quaisquer que sejam as opções tomadas pelo resenhista, o que faltar será tão importante quanto o que for discutido. O perigo é ainda maior quando se trata, como é indiscutivelmente o caso, de um autor que foi um dos ícones de uma geração e que agora é apresentado a outra. [...] Seria interessante tentar entender o que o livro Panamérica significou no final da década de 60, quando foi lançado. As pistas são inúmeras e claras: gigantes da cultura de massa envolvem-se em massacres, as estrelas de cinema hollywoodiano parecem tomar conta de tudo, funcionários do Dops perseguem o narrador e a guerrilha aparece em vários momentos. Mesmo consciente da sociedade contemporânea, agora que Hollywood não foi mesmo soterrada e todos sabemos que os adidos militares fizeram muito bem o seu trabalho. ${ }^{225}$

Passado tanto tempo da publicação inicial, o tom revisionista era apropriado. Foi nesse contexto que Agrippino passou a ser reconhecido de modo mais amplo como uma espécie de precursor do tropicalismo. Em um artigo publicado quando da segunda edição de

${ }^{224}$ OLIVEIRA, Nelson de. "Os cem melhores romances (esquecidos) do século". In: O século oculto e outros sonhos provocados. São Paulo: Escrituras Editora, 2002, p. 48-51.

${ }^{225}$ LÍSIAS, Ricardo. "Redescobrindo um ícone dos anos 60". In: Intervenções, álbum de crítica. Livro eletrônico. E-galáxia, 2014. 
Lugar público, Celso Favaretto apontou a "sintonia entre o modo de enunciação" de algumas obras surgidas naquele período agora distante:

Notável foi o ano de 1967: "Terra em Transe", "O Rei da Vela", Nova Objetividade Brasileira", o ambiente "tropicália", de Hélio Oiticica, a explosão das canções tropicalistas e este livro lendário, mas até agora pouco conhecido, de um artista também lendário. 226

Olhando para trás, é quase inegável, como observaria Favaretto, que a obra estava afinada com o que acontecia de mais inovador no teatro, no cinema e na música popular que se fazia no Brasil.

A partir dessa terceira edição do livro, a fortuna crítica do autor foi enriquecida. PanAmérica conta, hoje, com inúmeras abordagens e estudos diversos. Além dos trabalhos dedicados a esse livro, há outros que relacionam os romances de Agrippino com a produção de autores como André Sant'Anna, e também estudos comparativos com as produções do autor em outros suportes. ${ }^{227}$

${ }^{226}$ FAVARETTO, Celso Fernando. “A outra América”. In: Jornal de Resenhas, Folha de S. Paulo, 9/6/2001.

${ }^{227} \mathrm{Na}$ bibliografia deste trabalho, fizemos uma relação de estudos dedicados à obra de José Agrippino de Paula. 


\section{CONSIDERAÇÕES FINAIS}

Vimos neste estudo como uma compreensão particular da escrita resultou em um trabalho original nos romances de José Agrippino de Paula. As peculiaridades de sua obra geraram dificuldades para a crítica que, talvez encalacrada, viu-se diante de um impasse, para o qual a melhor saída foi o silêncio.

Entendemos esse fenômeno como uma consequência natural de uma obra operou por deslocamentos, raramente fazendo concessões e, mais do que isso, recusando postulados racionais. As composições de Agrippino buscam, o tempo todo, fugir da razão e do racional. Sua obra deslocada situa-se precisamente no terreno da desrazão. Por isso, entendemos e reconhecemos - porque também a sentimos - a dificuldade de estabelecer critérios ou buscar referências para uma obra que foge a qualquer referência dada ou critério estabelecido. No trabalho de Agrippino não há referencial racional. Mesmo quando são diretas, as referências são porosas, perdem-se, escapam, porque não estão lá para se prestar a uma leitura ou teoria dada de antemão.

Esses empecilhos são, naturalmente, fruto de uma produção radical. O esquecimento dos romances do autor não é um fenômeno que o atinge em particular, mas sim um traço característico de um tipo de produção que não segue os cânones e não faz concessões à forma. Assim como a dele, muitas outras obras de ruptura acabam relegadas a um lugar de menor destaque - ou de exceção.

Lugar público, e mais ainda PanAmérica, podem não ser obras inaugurais, sem precedentes, mas é interessante notar que poucos são os seus precedentes na literatura nacional. Quando eles podem ser apontados, isso ocorre por aproximação e não por filiação direta. Walnice Nogueira Galvão falou sobre a "alta tradição modernista" representada por obras como Macunaíma, de Mário de Andrade, e Serafim Ponte Grande e Memórias sentimentais de João Miramar, de Oswald de Andrade, para situar a obra de João Guimarães Rosa. ${ }^{228}$ E também Antonio Candido, ao comentar a ficção brasileira dos anos 1960 e 1970, disse:

${ }^{228}$ GALVÃO, Walnice Nogueira. "Sobre o regionalismo”. In: Mínima Mímica: ensaios sobre Guimarães Rosa. São Paulo: Companhia das Letras, 2008, p. 91. 
[...] ganha ímpeto o movimento ainda em curso de desliterarização, com a quebra dos tabus de vocabulário e sintaxe, o gosto pelos termos considerados baixos (segundo a convenção) e a desarticulação estrutural da narrativa, que Mário de Andrade e Oswald de Andrade haviam começado nos anos 20 em nível de alta estilização, e que de um quase idioleto restrito tendia agora a se tornar linguagem natural da ficção, aberta a todos. ${ }^{229}$

O crítico ainda reconheceu em Clarice Lispector a origem "das tendências desestruturantes, que dissolvem o enredo na descrição e praticam está com o gosto pelos contornos fugidios". ${ }^{230}$ Parece-nos que é precisamente nessa tendência que Agrippino se encaixa, anda que, ao nosso olhar, também aí ele pareça deslocado, "à margem de qualquer grupo", como a certa altura observa o narrador de Lugar público. ${ }^{231}$ Basta relembrarmos dos escritores brasileiros relacionados pelo autor no "inquérito": Jorge Mautner e Guimarães Rosa.

Ainda que hoje os romances do escritor sejam parte da tradição da literatura brasileira, devedor, inclusive, daquela "alta tradição modernista" de que falou Walnice Nogueira Galvão, suas referências são obras de vanguarda vindas no mais das vezes de fora, de outro lugar. ${ }^{232} \mathrm{E}$ esse fora pode ser tanto a produção literária estrangeira como as referências artísticas oriundas de outros meios de expressão, notadamente o cinema, mas também as artes plásticas.

Assim, os romances de Agrippino são um caso paradoxal na nossa produção. Ao mesmo tempo em que se afastam do contexto que os produziu, repelidos como ímãs de polos iguais, inserem-se naquela década de 1960 de modo profundo, como se um ímã os atraísse. Ao lançar mão de técnicas romanescas modernas e de uma imaginação prodigiosa para produzir uma literatura ímpar em um momento tão transformador, Agrippino fala, como disse

${ }^{229}$ CANDIDO, Antonio. “A nova narrativa”. In: A educação pela noite. São Paulo, Ática, 1999, p. 205.

${ }^{230}$ Idem, ibidem.

231 “(...) Uma relativa inabilidade social, ou uma inabilidade social absoluta, colocava os dois à margem de qualquer grupo. (...)" (PAULA, 1965, p. 17).

${ }^{232}$ No programa Lugar reservado, Agrippino volta a mencionar Jorge Mautner, William Faulkner e Franz Kafka, e cita também Nelson Rodrigues e Thomas Mann entre os autores que gostava. 
Paulo Leminski sobre Fiódor Dostoiévski, sobre o seu lugar, só que de uma posição diferente. Quando do relançamento de Lugar público, nos anos 2000, Carlos Heitor Cony disse:

Em geral esse tipo de literatura é altamente iconoclasta. Não, a literatura do Agrippino de Paula não foi uma literatura comportada, mas uma literatura que aceitava as regras do jogo. Apenas mostrava as regras do jogo de modo diferente. ${ }^{233}$

Talvez venha daí todo o incômodo e o estranhamento provocado por seus livros. Voltando àquela observação de Nogueira Moutinho sobre a opção futura do escritor depois de PanAmérica, podemos dizer que há, no experimentalismo de Agrippino, principalmente nesse escrito, uma radicalização da experiência do romance que coloca o autor diante do impasse sobre como continuar, o que fazer depois. Em literatura, tudo o que diz respeito a intenções pode não passar de especulação, mas o fato é que diversos autores, depois de escreverem romances seminais, não seguiram produzindo obras no gênero, talvez com medo de não conseguirem atingir o grau de inovação de suas obras, talvez por se darem por satisfeitos e terem julgado que seu trabalho estava feito, que o recado estava dado.

Há exceções. É fácil pensarmos em James Joyce radicalizando ainda mais as experimentações do Ulysses no Finnegans Wake. Mas, para confirmar a regra, podemos pensar em Guimarães Rosa, que escreveu apenas um romance, precisamente o Grande sertão: veredas, ou em J. D. Sallinger, que nada mais publicou depois de $O$ apanhador no campo de centeio. Ou ainda, para ficarmos no exemplo de um autor contemporâneo de Agrippino, em Raduan Nassar, que depois de Lavoura arcaica produziu um dos silêncios mais incômodos da nossa literatura. Todas essas são obras que ousaram romper limites formais e, assumimos a especulação, levaram seus realizadores a um limite que não pôde mais ser transposto.

Foi esse o destino de José Agrippino de Paula depois de PanAmérica. Com seus narradores obsessivos e blocos narrativos isolados; com sua imaginação delirante e, mais do que isso, desconcertante; com a utilização de nomes das personalidades históricas e a

${ }^{233}$ Programa Lugar Reservado (Sesc TV, 2005). 
apropriação de seres e de coisas pertencentes, além da própria História, também à indústria cultural e à cultura de massa, seus romances criaram um universo particular e original que, justamente por isso, destoou da produção do período.

Ambas as obras terminam com a sequência de acontecimentos que os caracterizou. Banais, mas captados em um tom singelo e poético em Lugar público, extraordinários, hiperbólicos e irrefreáveis em PanAmérica. Os narradores, que muito viram e descreveram o que foi visto, veem ao final um grande espetáculo, seja uma representação da realidade feita pelo homem e exibida "na sala de projeção escura", seja a própria realidade em sua totalidade, com os personagens penetrando a órbita do planeta. No limite, é a visão que se impõe. É a visão que pode estabelecer alguma ordem no caos imposto. E não podemos deixar escapar que, enquanto Lugar público termia com o narrador-protagonista entrando na sala de cinema, PanAmérica começa justamente com uma filmagem.

Depois dessa experiência, continuar com o romance talvez tenha sido impossível para o autor. Basta que nos lembremos de Terracéu e de Os favorecidos de madame Estereofônica, suas duas tentativas malogradas. Diante da radicalidade de sua obra no romance, podemos pensar que a experiência do autor trataria do fim da própria ficção e, no termo, do fim da própria literatura.

Levando os elementos composicionais do romance ao limite, expondo o processo de escrita, abrindo mão da individualidade e da psicologia das personagens, rompendo com as barreiras da representação e do realismo, colocando em cena as multidões de seres e de coisas, Agrippino parece, muitas vezes, estar fazendo uma outra coisa que, de vasta e delirante, é de difícil definição. O diário de um louco, a descrição de um filme, uma sequência de eventos protagonizados por seres, coisas e acontecimentos mitológicos e extraordinários ou apenas uma narrativa ficcional pura que, mesmo recorrendo a referências externas, dá a essas referências aquela autonomia que só a ficção permite. Se, como disse Marthe Robert, o romance tira sua força precisamente de sua absoluta liberdade, a obra de José Agrippino de Paula soube se situar precisamente nesse lugar libertário dentro da literatura. 


\section{REFERÊNCIAS}

\section{Obra literária de José Agrippino de Paula}

Crime e castigo. Teatro. 1961. Adaptação do romance de Fiódor Dostoiévski. Inédito. Consta no acervo da Sociedade Brasileira de Autores Teatrais (Sbat).

A letra escarlate. Roteiro para televisão adaptado do romance de Nathaniel Howthorne. 1962. Inédito. Acervo Sbat.

Lugar público. Romance. Civilização Brasileira, Rio de Janeiro, 1965. Editora Papagaio, 2004.

As Nações Unidas. Teatro. 1966. Inédito. Classificada pelo autor como "show", essa peça contém os textos de Os enfermeiros do rei e A guerra atômica, ambos escritos por José Agrippino de Paula. As três obras integram o acervo da Sbat.

The United Nations. Translated by John Procter. Rio de Janeiro: edição do autor, 1968.

PanAmérica. Romance. Rio de Janeiro: Tridente, 1967. São Paulo: Max Limonad, 1988. São Paulo, Papagaio, 2001.

"Roteiro de viagem do diário oficial das drogas do Ocidente". Narrativa. In: Revista Ânima, Rio de Janeiro: abril-março de 1976. In: Revista Azougue nº 8. Rio de Janeiro, abril de 2003.

"Tribo do mar e do ar sagrado: quatro fragmentos de um livro". In: Revista Planeta n ${ }^{\circ} 24$, São Paulo: Editora Três, agosto de 1974.

"Na alameda dos baobás". Conto. In: Revista Caspa n ${ }^{\circ}$ 1, revista de Letras da USP, Cael, 1977a.

“A cigana prateada da lua". Conto. In: Revista Ficção n 19, julho de 1977b.

"Som do divino maravilhoso". Conto. S. d. Inédito.

\section{Obras sobre José Agrippino de Paula}


ARAÚJO, André Corrêa da Silva de. "As vidas imaginadas de Marilyn Monroe: o uso de nomes próprios na literatura contemporânea brasileira como metalinguagem dos meios de comunicação". Trabalho apresentado no XXXVII Congresso Brasileiro de Ciências da Comunicação. Foz do Iguaçu, PR - 2 a 5/9/2014.

ARRUDA, Vinicius Galera de. O Homem Hibernado, a vida de José Agrippino de Paula. Trabalho de Conclusão de Curso. Escola de Comunicações e Artes da Universidade de São Paulo (ECA-USP), dezembro de 2010.

BENTO, Carlos Henrique. "Delirante Panamérica". In: Revista Literária do Corpo Discente da Universidade Federal de Minas Gerais. Ano XXXVI, n² 27. Belo Horizonte, 2001/2002. . Os anos sessenta em PanAmérica, de José Agrippino de Paula: pop, guerrilha, performance. Mestrado em Teoria da Literatura na Universidade Federal de Minas Gerais em 2002. - "Pan e Latina América: o delírio épico de José Agrippino de Paula”. In: Revista Ipotesi (UFJF), V. 12, p. 145-153. Juiz de Fora, MG, 2008.

CASTANHEIRA, Daniel Fernandes. O lugar público de Agrippino. Trânsito e espacialidade na cidade-qualquer. Mestrado em Letras na Pontifícia Universidade Católica do Rio de Janeiro em 2009.

CUNHA, Juliana Andrade. "Sujeito e cultura: o que pode nos ensinar o texto literário PanAmérica de José Agrippino de Paula?" In: Anais do II ENECULT - Encontro de Estudos Multidisciplinares em Cultura, 2006.

. Sujeito e cultura na virada dos anos 60: contribuições para o debate a partir de PanAmérica epopeia de José Agrippino de Paula. Mestrado em Cultura e Sociedade na Universidade Federal da Bahia em 2007.

FALCÃO, Marisa Aurea de Sá. "Viagens virtuais: jogos do devir no tempo móvel de Grande sertão: veredas, Panamérica e Corra Lola, corra”. In: Anais eletrônicos do XIV Abralic. Universidade Federal do Pará. Belém, 2014.

HOISEL, Evelina. Supercaos: os estilhaços da cultura em PanAmérica e Nações Unidas. Rio de Janeiro: Civilização Brasileira; Salvador: Fundação Cultural do Estado da Bahia, 1980. 
. "PanAmérica: uma cartografia dos processos de globalização nos anos de 1960". In: Recôncavos (Revista do Centro de Artes, Humanidades e Letras vol. 2 (I), 2008.

MADAZZIO, Irlainy Regina. $O$ voo da borboleta, a obra cênica de José Agrippino de Paula e Maria Esther Stockler. Mestrado em Artes na Escola de Comunicações e Artes da Universidade de São Paulo em 2005.

MELO, Izabel de Fátima Cruz. "O eu que só pode ser (n)o outro: Jean Rouch e José Agrippino nas Áfricas dos Anos 1970”. VII Simpósio Nacional de História Cultural. Universidade de São Paulo, 10 e 14 de novembro de 2014.

MONTENEGRO, Tatiana Martins. "O reflexo da pós-modernidade na cultura e na literatura: uma breve visão de PanAmérica”. In: Revista Hispeci \& Lema On-line - no IV - n. 4 - p. 33-38 - Bebedouro, SP, nov. 2013.

MORAES, Felipe Augusto de. A arte-soma de José Agrippino de Paula. Mestrado em Meios e processos audiovisuais na Escola de Comunicações e Artes da Universidade de São Paulo em 2011.

Contemporâneos $\mathrm{n}^{\circ}$ 10. Maio - outubro de 2012.

OLIVEIRA, Leandro Salgueirinho de. "A ficção de André Sant'Anna e o livro PanAmérica, de José Agrippino de Paula". In: Revista Icarahy, v. 1. Universidade Federal Fluminense, 2009.

OTTATI, Rafael. “O esfacelamento do sagrado em PanAmérica”. In: Revista Garrafa nº 29. Universidade Federal do Rio de Janeiro,janeiro-março de 2013. . "Desligitimação através do corpo feminino em PanAmérica de José Agrippino de Paula”. Revista Garrafa 31. Universidade Federal do Rio de Janeiro, julho-setembro de 2013.

PORTELLA, Romuldo de Almeida. Linguagem experimental: o discurso do consumo em Sexo, de André Sant'Anna, e o discurso da 'existencialidade' em Lugar Público, de José Agrippino de Paula. Mestrado em Letras na Universidade Estadual do Rio de Janeiro em 2006. 
UCHÔA, Fabio Raddi. "A colagem na obra de José Agrippino de Paula: migração de procedimentos entre literatura, teatro e cinema". In: Contemporânea-Revista de Comunicação e Cultura (UFBA, Online), v. 13, p. 225-241, 2015. - "Procedimentos da pop arte em Hitler III' Mundo (1969), de José Agrippino de Paula”. In: Cadernos de resumos. São Paulo: SOCINE, 2009.

VIANA, Marcelo Andrade. Estilhaçamentos espelhados: o narrador, os espaços da narrativa e a cidade em Lugar público, de José Agrippino de Paula. Mestrado em Estudos Literários na Universidade Federal de Minas Gerais em 2012.

- “José Agrippino de Paula: inovação e experimentação no contexto da produção cultural dos anos 1960”. In: Revista Estação literária. Volume 12, p. 437-451. Londrina, jan, 2014.

\section{Obras consultadas}

\subsection{Livros e publicações acadêmicas}

ADORNO, Theodor W. "Posição do narrador no romance contemporâneo". In: Notas de literatura I. Tradução de Jorge de Almeida. São Paulo, Editora 34, 2003.

ANDERS, Günter. Kafka: pró e contra. Tradução de Modesto Carone. São Paulo: Perspectiva, 1993.

ANDRADE, Mário. Macunaíma, o herói sem nenhum caráter. Rio de Janeiro: Agir, 2007.

BARTHES, Roland. Crítica e verdade. Tradução de Leyla Perrone-Moisés. São Paulo, Perspectiva, 2013a.

Mitologias. Tradução de Rita Buongermino, Pedro de Souza e Rejane Janowitzer. $7^{\text {a }}$ edição. Rio de Janeiro, Difel, 2013 b.

. O prazer do texto. Tradução de J. Guinsburg. 6a edição. São Paulo:

Perspectiva, 2013.

BATAILlE, Georges. O erotismo. Tradução de Fernando Scheibe. Belo Horizonte: Autêntica, 2014. 
BLANCHOT, Maurice. O espaço literário. Tradução de Álvaro Cabral. Rio de Janeiro: Rocco, 2011.

BOSI, Alfredo. História concisa da literatura brasileira. $43^{\text {a }}$ edição. São Paulo, Cultrix, 2006.

BUTOR, Michel. Repertório. Tradução de Leyla Perrone-Moisés. São Paulo: Perspectiva, 1974.

CALLADO, Antonio. Quarup. Rio de Janeiro: Nova Fronteira, 2006.

CALVINO, Italo. Por que ler os clássicos. Tradução de Nilson Moulin. São Paulo: Companhia das Letras, 2007.

. Seis propostas para o próximo milênio. $2^{\mathrm{a}}$ edição. Tradução de Ivo Barroso. São Paulo: Companhia das Letras, 1998.

CAMPOS, Augusto de. "De Ulysses a Ulisses". In: Panaroma do Finnegans Wake. 4 ed. rev. e ampl. São Paulo, Perspectiva, 2001.

CANDIDO, Antonio. “A nova narrativa”. In: A educação pela noite. São Paulo, Ática, 1999.

CARONE, Modesto. Essencial Franz Kafka / seleção, introdução e tradução de Modesto Carone. São Paulo: Penguin Classics Companhia das Letras, 2011. . Lição de Kafka. São Paulo: Companhia das Letras, 2009.

CARPEAUX, Otto Maria. História da literatura ocidental. Volume IV. Brasília, Edições do Senado Federal, 2010.

COELHO, Cláudio Novaes Pinto. "A contracultura: o outro lado da modernização autoritária”. In: Anos 70: trajetórias. São Paulo: Iluminuras, Itaú cultural, 2005.

CONY, Carlos Heitor. "Apresentação”. In: Lugar público. Rio de Janeiro, Civilização Brasileira, 1965.

. Pesach, a travessia. São Paulo: Companhia das Letras, 2002.

DANTO, Arthur C. Andy Warhol: Arthur C. Danto. Tradução de Vera Pereira. São Paulo: Cosac Naify, 2012.

DELEUZE, Gilles. Crítica e clínica. Tradução de Peter Pál Pelbart. $2^{a}$ edição. São Paulo: 34, 2013.

DIAS, Antonio. Anywhere is my land. Catálogo da mostra apresentada na Pinacoteca do Estado de São Paulo entre 11 de setembro e 7 de novembro de 2010. 
DOSE, Francis. O desafio biográfico. Tradução de Gilson César Cardoso de Souza. São Paulo: Edusp, 2009.

FAVARETTO, Celso Fernando. Tropicália, alegoria, alegria. $4^{\mathrm{a}}$ edição. Cotia, SP: Ateliê Editorial, 2007. . A invenção de Helio Oiticica. $2^{\text {a }}$ edição. São Paulo: Editora da Universidade de São Paulo, 2015.

FAULKNER, William. "Entrevista". In: Os escritores: as históricas entrevistas de Paris Review / [seleção Marcos Maffei]; tradução de Alberto Alexandre Martins, Beth Vieira. São Paulo: Companhia das Letras, 1988.

FORSTER, Edward Morgan. Aspectos do romance. Tradução de Maria Helena Martins. $2^{\mathrm{a}}$ edição. São Paulo: Globo, 1998.

GALVÃO, Walnice Nogueira. "Sobre o regionalismo”. In: Mínima Mímica: ensaios sobre Guimarães Rosa. São Paulo: Companhia das Letras, 2008.

GOLDMANN, Lucien. Sociologia do Romance. Tradução de Álvaro Cabral. $3^{\mathrm{a}}$ edição. Rio de Janeiro, Paz e Terra, 1976.

GOTLIB, Nádia Batella. Clarice: uma vida que se conta. $7^{\text {a }}$ Edição. São Paulo: Edusp, 2015.

HOISEL, Beto. Naquele tempo em Arembepe. $2^{\text {a }}$ edição. Salvador: Século 22, 2003.

JOYCE, James. Ulysses. Tradução de Caetano W. Galindo. São Paulo: Penguin Classics Companhia das Letras, 2012.

KLINGER, Diana Irene. Escritas de si, escritas do outro: autoficção e etnografia na narrativa latino-americana contemporânea. Doutorado em Literatura Comparada no Instituto de Letras da Universidade do Estado do Rio de Janeiro em 2006.

LEITE, Lígia Chiappini Moraes. O foco narrativo. 10a edição. São Paulo: Ática, 2004.

LEMINSKI, Paulo. “Trótski, a paixão segundo a revolução”. In: Vida: Cruz e Souza: Bashô: Jesus: Trótski. $2^{\mathrm{a}}$ edição. Porto Alegre: Sulina, 1998.

LINS, Osman, Guerra sem testemunha. São Paulo: Martins, 1969.

LÍSIAS, Ricardo. “Redescobrindo um ícone dos anos 60”. In: Intervenções, álbum de crítica. Livro eletrônico. E-galáxia, 2014

MAUTNER, Jorge. Deus da chuva e da morte. Goiânia, Editora Kelps, 1997.

MACHADO, Ana Maria. Recado do nome: leitura de Guimarães rosa à luz do Nome de seus personagens. São Paulo: Companhia das Letras, 2013. 
MORAES, Eliane Robert. O corpo impossível a decomposição da figura humana: de Lautréamont a Bataille. São Paulo: Iluminuras, 2002.

MOUTINHO, José Geraldo Nogueira. A fonte e a forma. Rio de Janeiro, Imago, 1977.

NITRINI, Sandra Margarida. Poéticas em confronto: Nove, novena e o novo romance. São Paulo: Hucitec; Brasília: INL, Fundação Nacional Pró-Memória, 1987.

NUNES, Benedito. O tempo na narrativa. São Paulo: Edições Loyolla, 2013.

OLIVEIRA, Nelson de. "Os cem melhores romances (esquecidos) do século". In: O século oculto e outros sonhos provocados. São Paulo: Escrituras Editora, 2002.

PASSOS, José Luiz. Ruínas de linhas puras: quatro ensaios em torno a Macunaíma. São Paulo: Annablume, 1998.

PELBART, Peter Pál. Da clausura do fora ao fora da clausura, loucura e desrazão. São Paulo: Brasiliense, 1989.

PERRONE-MOISÉS, Leyla. O novo romance francês. São Paulo: São Paulo Editora S. A. 1966.

Altas literaturas: escolha e valor na obra crítica de escritores modernos. São Paulo, Companhia das Letras, 2009.

PINO, Claudia Amigo. A ficção da escrita. Cotia, SP: Ateliê Editorial, 2004.

RAPHAEL, Frederic. Kubrick de olhos bem abertos. São Paulo: Geração Editorial, 1999.

REUTER, Yves. A análise da narrativa. Tradução de Angela Bergamini, Milton Arruda, Neide Sette e Clemence Jouêt-Pastré. $4^{\mathrm{a}}$ edição. Rio de Janeiro: Difel, 2014. . Introdução à análise do romance. Tradução de Mario Pontes. $2^{\mathrm{a}}$ edição. São Paulo: Martins Fontes, 2004.

RISÉRIO, Antonio. "Duas ou três coisas sobre a contracultura no Brasil". In: Anos 70: trajetórias. São Paulo: Iluminuras, Itaú cultural, 2005.

ROBERT, Marthe. "Por que romance?” In: Romance das origens, origens do romance. Tradução de André Telles. São Paulo: Cosac Naify, 2007.

ROBBE-GRILLET, Alain. Por um novo romance. Tradução de Cristóvão Santos. Lisboa, Publicações Europa América, 1965. . O ciúme. Tradução de Waltensir Dutra. São Paulo: Círculo do livro, 1992. 
ROSENFELD, Anatol. “À procura do mito perdido: notas sobre a crise do romance psicológico. In: Letras e leituras. São Paulo: Perspectiva, 1994.

• "O rito do amor selvagem". In: Prismas de teatro. São Paulo:

Perspectiva: Editora da Universidade de São Paulo; Campinas: Editora da Universidade Estadual de Campinas, 1993.

. "Reflexões sobre o romance moderno". In: Texto/Contexto I. $5^{\mathrm{a}}$ edição. São Paulo: Perspectiva, 1996.

ROSZAK, Theodore. A contracultura. Tradução de Bruno Palma. Petrópolis, RJ: Vozes, 1972.

SCHENBERG, Mario. “Apresentação”. In: PanAmérica. Rio de Janeiro, Tridente, julho de 1967.

SCHWARZ, Roberto. “Cultura e política, 1964-69”. In: O pai de família e outros ensaios. São Paulo, Companhia das letras, 2008.

. "Verdade tropical: um percurso de nosso tempo". In: Martinha versus Lucrécia: ensaios e entrevistas. São Paulo, Companhia das letras, 2012.

TODOROV, Tzvetan. “As categorias da narrativa literária”. In: Análise estrutural da narrativa. Tradução de Maria Zélia Barbosa Pinto. Vozes: Petrópolis, RJ, 1971. . Introdução à literatura fantástica. Tradução de Maria Clara Correa Castello. São Paulo: Perspectiva, 1975.

VELOSO, Caetano. “Prefácio”. In: PanAmérica. $3^{\text {a }}$ edição. São Paulo, Papagaio, 2001. . Verdade tropical. São Paulo, Companhia das Letras, 1997.

XAVIER, Ismail. Alegorias do subdesenvolvimento, cinema novo, tropicalismo, cinema marginal. São Paulo: Cosac Naify, 2012.

\subsection{Jornais, revistas e internet}

“A volta de José Agrippino de Paula, o bruxo de Embu". Autoria não creditada. O Estado de S.Paulo, São Paulo, 6 abril 2001. Atualizado em 3 març. 2012. Disponível em: http://cultura.estadao.com.br/noticias/geral,a-volta-de-jose-agrippino-de-paula-obruxo-de-embu,20010406p3412 
"Reportagem astral na praia do Cheganêgo". Depoimento de José Agrippino de Paula. In: Revista Ânima n ${ }^{\circ}$ 2. Rio de Janeiro, abril de 1977.

"Panamérica", uma epopeia continental. Autoria não creditada. Folha de S. Paulo, São Paulo, 16 ago 1967.

ANTÔNIO, João. "Inquérito: o romance urbano". In: Revista Civilização Brasileira n 7 , Rio de Janeiro, Civilização Brasileira, maio de 1966.

CHIH, Chiu Ui. "José Agrippino de Paula e seu romance pós-moderno PanAmérica”. In: Revista Zunái. São Paulo, 29 abr. 2011.

BRESSANE, Ronaldo e TERRON, Joca Reiners. "O Desfavorecido de Madame Estereofônica”. In: Revista Trip, São Paulo, junho de 2007a. http://revistatrip.uol.com.br/155/desplugados/02.htm

BRESSANE, Ronaldo. "Vai passando uma época". Publicado no blog $O$ impostor, de Ronaldo Bressane, em 27 de setembro de 2006. Disponível em: http://ronaldobressane.com/2006/09/27/vai-passando-uma-epoca/ . “Agrippino, o profeta da Tropicália". O Estado de S. Paulo, São Paulo, 9 de fevereiro de 2007b. Disponível em: http://cultura.estadao.com.br/noticias/artes, agrippino-o-profeta-da-tropicalia, 44985

EZABELLA, Fernanda. "Editor abre baú de Agrippino de Paula, símbolo do movimento tropicalista”. Folha de S. Paulo, São Paulo, 19 jan. 2009. Disponível em: http://www1.folha.uol.com.br/fsp/ilustrad/fq1901200922.htm

FAVARETTO, Celso Fernando. "A outra América". In: Jornal de Resenhas, Folha de S. Paulo, 9/6/2001.

GRAIEB, Carlos. “Sem lenço e sem documento”. In: Revista Veja, São Paulo, s. d.

MACHADO, Cassiano Elek. "Sou um filiado da pop art", diz Agrippino. Folha de S. Paulo. São Paulo, 5 de abril de 2004. Disponível em: http://www1.folha.uol.com.br/folha/ilustrada/ult90u44752.shtml

MEDEIROS, Jotabê. Autor antecipou o "faça você mesmo". O Estado de S.Paulo, São Paulo, 8 de novembro de 2008. Disponível em: http://cultura.estadao.com.br/noticias/artes,autor-antecipou-o-faca-voce$\underline{\text { mesmo, } 274394}$ 
SANT'ANNA, Sérgio. “A utopia de José Agrippino”. In: Caderno Mais!, Folha de S. Paulo, 23/2/1997.

SCOFIELD Jr., Gilberto. “A montanha de inéditos de José Agrippino de Paula”. O Globo, Rio de Janeiro, 16 de outubro de 2010. Indisponível.

SODRÉ, Nelson Werneck. “O movimento literário”. In: Revista Civilização Brasileira n 7 , maio de 1966.

TRAJANO, Gérson. "Panaméricas vivas". Portal Literal. Rio de Janeiro (RJ) • Publicado originalmente em 9/6/2003 e atualizado em 29/7/2008. Disponível em: https://issuu.com/revista_portal_literal_2012/docs/revista_literal_n._03/38

VELOSO, Caetano. “Um irracionalista radical”. Folha de S. Paulo, São Paulo, 16 dez 1984.

VASCONCELOS, Maurício Salles. “José Agrippino de Paula”. In: Sibila, revista de poesia e crítica literária. 31 de março de 2010. Disponível em: http://sibila.com.br/critica/jose-agrippino-de-paula/3504

\subsection{Programas de televisão e documentários}

- Espaço Aberto Literatura, 2001, Betacam, 30 min. Globo News. Entrevista de José Agrippino de Paula a Pedro Bial por ocasião do relançamento de PanAmérica.

- Lugar Reservado, 2005, 30 min - Sesc TV. Entrevista de José Agrippino a Ricardo Soares por ocasião do relançamento de Lugar Público. Direção: Ricardo Soares.

Disponível em:

http://tal.tv/video/jose-agrippino-de-paula-lugar-reservado/

\subsection{Entrevistas dadas ao autor:}

Antonio Dias. Realizada em São Paulo em 7 de outubro de 2010.

Caetano Veloso. Realizada por e-mail em 19 de junho de 2012. 
Edwaldo Cafezeiro. Realizada por telefone em 14 de agosto de 2012.

Evelina Hoisel. Realizada por telefone em 28 de julho de 2014.

Jorge Bodanzki. Realizada em São Paulo em 14 de outubro de 2010.

\subsection{Fontes bibliográficas das epígrafes}

\section{Introdução}

ROBBE-GRILLET, Alain. Por um novo romance. Tradução de Cristóvão Santos. Lisboa, Publicações Europa América, p. 196.

\section{Capítulo 1}

PAULA, José Agrippino. Lugar público. Civilização Brasileira, Rio de Janeiro, 1965, p. 172.

\section{Capítulo 2}

PAULA, José Agrippino de. PanAmérica. Rio de Janeiro: Tridente, 1967, p. 177.

\section{Capítulo 3}

ANTÔNIO, João. "Inquérito: o romance urbano". In: Revista Civilização Brasileira n 7, Rio de Janeiro, Civilização Brasileira, maio de 1966, p. 220. 


\subsection{Créditos das ilustrações}

p. 76. Diagramação de Valter Silva.

P. 110. DIAS, Antonio. Anywhere is my land. Catálogo da mostra apresentada na Pinacoteca do Estado de São Paulo entre 11 de setembro e 7 de novembro de 2010, p. 169. 


\title{
ANEXO \\ "SOM DO DIVINO MARAVILHOSO"
}

\author{
José Agrippino de Paula
}

Encontrei muita gente devota do Krishna, mas eles não eram do Hare Krishna. Iam no templo, falavam com devotos, tinham altares em casa, mas não pertenciam ao movimento. Adma, Terry, Rick, Lokabando. Mas foi com Lokabando, um venezuelano Hare Krishna, que conversamos sobre a iluminação de Brahma. Brahma é um Deus, talvez seja o Deus de Abraão, Jacó e Cristo. "O Deus Que Criou o Mundo", o Criador na trindade indu, O Demiurgo.

Sendo o Criador era completo e partiu no seu planeta em busca da luz. A luz é a iluminação e foi Brahma deus supremo viajando no espaço escuro em busca de luz. O espaço escuro e vazio de matéria era imenso e Brahma sobre o seu planeta, o Planeta de Brahma, Planeta Bramânico. Não sei quantas eternidades ou quantos anos Bramânicos, que são milhões de anos, viajou Brahma no espaço escuro e não encontrou a luz.

Lokabando fazia perfumes e ainda hoje usa a essência de sândalo. Lokabando vendia perfumes. Veio do Rio de Janeiro e já tinha ido à Índia com os Hare Krishna.

De noite aqui na Boca do Rio, na Bahia, nós íamos para um coqueiral escuro e fazíamos um som de violão, atabaque e bumbo, em devoção a Krishna e Lokabando cantava uns mantras e tocava um bumbo de cabaça que eu tinha feito. Era um bumbo feito de uma cabaça grande, cipó e couro de cabra e tirantes de algodão. Parecia um tambor indu ou barbére. Foi roubado na casa do Joyldo, que era muita confusão de gente. Deixei na grama do quintal e roubaram. Brahma o Criador viajou no espaço escuro um tempo que a mente humana não poderá alcançar e não encontrou a luz. Na profunda solidão do universo escuro Brahma ficou perdido.

Brahma Loka é planeta de Brahma, mas eu não sei o que é Lokabando. São muitos os estágios dos planetas celestiais. Planetas celestiales dizia Lokabando e eu passei a chamá-lo de Planeta Celestial. A iluminação de Brahma foi uma conversa que eu tive com Lokabando. Foi um dia de oferenda a Krishna no aniversário de Alan. Eu fiz um pão de passas, ameixa, 
canela, cravo e mel, e o Planeta Celestial fez um arroz integral com legumes, cominho, açafrão, passas e manteiga. Krishna gosta muito de manteiga e cominho.

Brahma viaja no seu planeta, Planeta Bramânico, no fundo do universo escuro e escuta da abóbada do Universo duas sílabas TA PA que soa de fora do seu universo escuro. Krishna de fora do Universo escuro produz o som das duas sílabas sagradas TA PA. Brahma que seguiu procurando a iluminação só encontrou o escuro no seu espaço. De fora do espaço de Brahma de um espaço transcendente e iluminado por Krishna surgiu o som sagrado das duas sílabas TA PA. Não sendo iluminado pela luz, Brahma na profundidade da sua solidão no seu universo escuro apareceu o som sagrado, ecoando de fora da abóbada do seu universo. A iluminação do Deus Criador surgiu com o som de Krishna para a luz e energia de som e luz. Foi a iluminação de Brahma no seu Universo escuro. O Deus da Criação Brahma foi salvo na solidão do seu Universo completamente escuro pelo som sagrado TA PA dito por Krishna. 